\title{
Social Capital Structure and Dynamics in Stream Restoration: A Social Network Analysis Approach to the Upper Shavers Fork, West Virginia
}

Paul J. Kinder Jr.

Follow this and additional works at: https://researchrepository.wvu.edu/etd

\section{Recommended Citation}

Kinder Jr., Paul J., "Social Capital Structure and Dynamics in Stream Restoration: A Social Network Analysis Approach to the Upper Shavers Fork, West Virginia" (2017). Graduate Theses, Dissertations, and Problem Reports. 7101.

https://researchrepository.wvu.edu/etd/7101

This Dissertation is protected by copyright and/or related rights. It has been brought to you by the The Research Repository @ WVU with permission from the rights-holder(s). You are free to use this Dissertation in any way that is permitted by the copyright and related rights legislation that applies to your use. For other uses you must obtain permission from the rights-holder(s) directly, unless additional rights are indicated by a Creative Commons license in the record and/ or on the work itself. This Dissertation has been accepted for inclusion in WVU Graduate Theses, Dissertations, and Problem Reports collection by an authorized administrator of The Research Repository @ WVU.

For more information, please contact researchrepository@mail.wvu.edu. 
Social Capital Structure and Dynamics In Stream Restoration: A Social Network Analysis Approach to the Upper Shavers Fork, West Virginia.

Paul J. Kinder, Jr.

Dissertation submitted to the Davis College of Agriculture, Natural Resources, and Design at West Virginia University in partial fulfillment of the requirements for the degree of

Doctor of Philosophy in Resource Economics and Management/Human and Community Development

\author{
Michael Strager, Ph.D., Chair \\ Steve Selin, Ph.D. \\ Jerald Fletcher, Ph.D. \\ Charles Yuill, MLA \\ Bryan Mark, Ph.D. \\ Department of Resource Economics and Management
}

Morgantown, West Virginia

2017

Keywords: Social Capital, Social Network Analysis, Social Network Dynamics, Stream Restoration, Adaptive Natural Resource Governance, Co-Management, Common Pool Resource Management, Polycentric Governance

Copyright 2017 Paul J. Kinder, Jr. 


\begin{abstract}
Social Capital Structure and Dynamics In Stream Restoration: A Social Network Analysis Approach to the Upper Shavers Fork, West Virginia.
\end{abstract}

Paul J. Kinder, Jr.

Streams are common pool resources embedded in watersheds representing complex socioecological systems that provide ecological goods and services as well as economic and social benefits. They have been referred to as the lifeblood of civilization. Streams, however, are among the most vulnerable natural resources globally to anthropocentric impacts and are all too often in need of restoration. While the primary objective of stream restoration is to bring back healthy ecological functions, other benefits and outcomes from restoration efforts exist, but are often overlooked. These benefits and outcomes relate to effective natural resource governance systems, which rely on social networks comprised of social capital. Moreover, social networks are the infrastructure of the social capital underpinning collaborative effort, co-management, and adaptive natural resource governance. In the case of stream restoration in the Upper Shavers Fork of West Virginia, research has confirmed that social network structure and character are related to adaptive natural resource governance, performance, and perhaps more importantly, studying network structural dynamics yields greater insights than merely performing analyses on a single slice in time. While results indicate an emergence and persistence of adaptive and polycentric governance structures in the Upper Shavers Fork restoration effort, a core-periphery pattern also endured with the same three key organizations holding the most central network positions during all time periods studied. This research provides empirical results linking natural resource governance effectiveness to network structure and dynamics which has been deemed lacking in the literature to date, and also, provides a useful example of stream and watershed restoration to inform and guide future efforts in West Virginia, and beyond. 
Acknowledgements

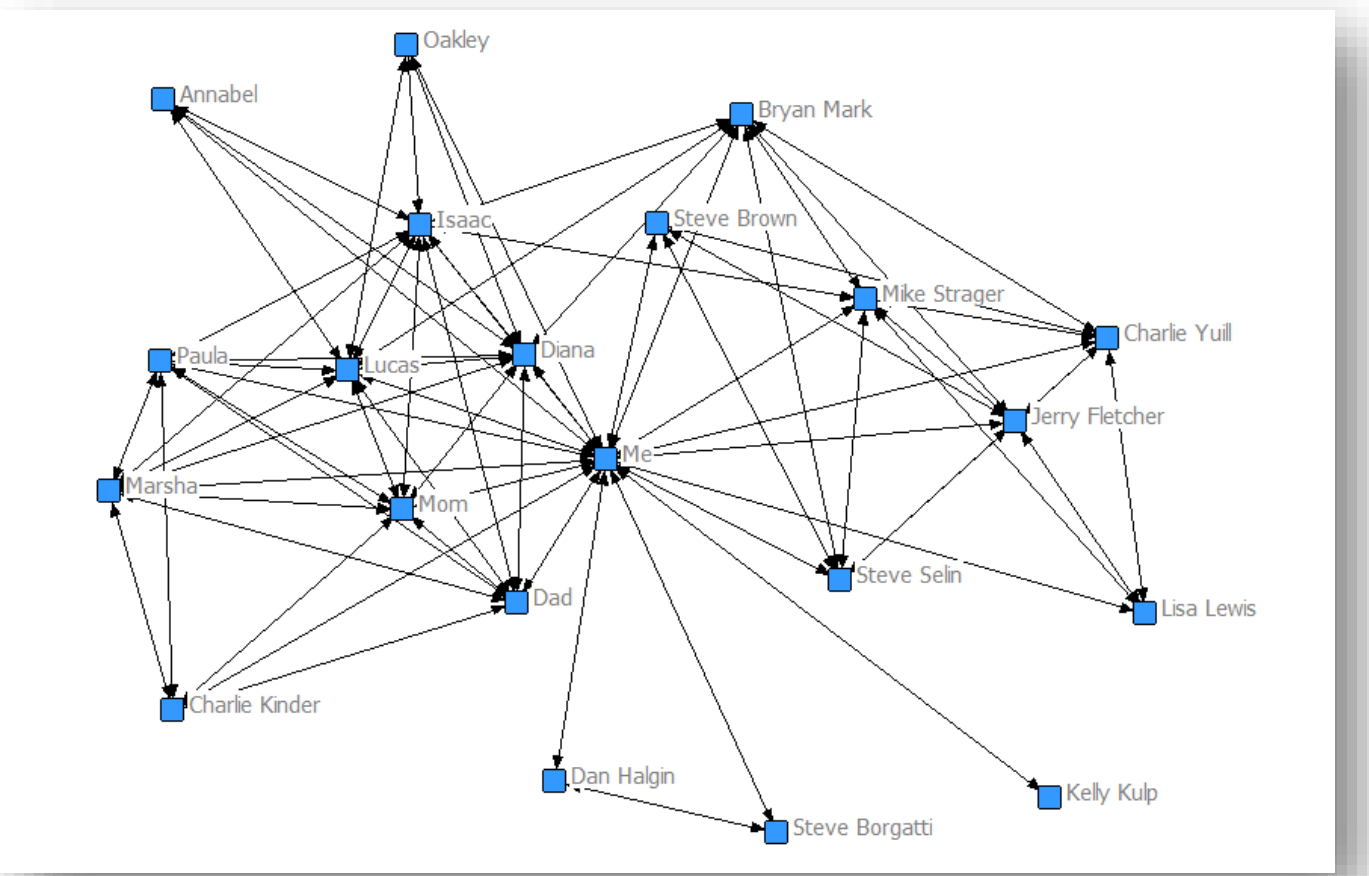

"And we know that for those who love God all things work together for good..."

- Romans 8:28 NIV

What better way to kickoff acknowledgements in a dissertation on social capital than with a network diagram of those so dear and helpful to me along the way?

I first wish to remember my hero and granddad Charlie Kinder who slaved in the WV coal mines for over 40 years. He loved his family, rivers, and fishing. Somehow he had the foresight to insist that my Dad go to college despite the fact that everyone around him only knew the mines. Dad was the youngest child and the first of the Kinder clan to get a college degree. Dad and Mom always put our interests first and are truly amazing parents. Hence, I dedicate this work to them thank you Mom and Dad and I dearly love and appreciate you both. Mom and Dad were sure to 
put my sisters, Marsha and Paula, through college as well; they became our family's first registered nurses and proud graduates of West Virginia University. Marsha and Paula were extremely good to me as well. As the little brother, I really had three mothers that pushed me to succeed. Marsha died after a long battle with multiple sclerosis, and I only wish she could see me complete this degree and accompany me on jet ride to celebrate somewhere special on planet Earth.

Working full time while pursuing a $\mathrm{PhD}$ is challenging stuff, but I have a wonderful wife and family that supported me every step of the way. To my wife Diana, thank you for your unending support and feeding me intellectually, spiritually, and literally when the hours turned into days and days into months and months into years. Lucas and Isaac, my sons, have also been supportive; I thank God for them, and I appreciate them jumping in to help with family duties and distracting me with fun times. Oakley and Annabel are my basset hound study buddies and are always quick to serve as a lap desk to support my reading materials even late into the night.

I wish to thank Steve Brown for his continual friendship and guidance as we worked diligently together on the Upper Shavers Fork (USF) restoration effort and many other projects. Without Steve Brown, I am pretty sure the restoration of USF would still be just a dream. To my graduate committee: Mike Strager, Steve Selin, Jerry Fletcher, Charlie Yuill, and Bryan Mark, I thank you for your direction, encouragement, and mentorship. You are my colleagues and my friends, and I will always appreciate your dedication to my cause. Thank you Lisa Lewis for taking care of me and making sure I stayed on track; you remind me, in so many ways, of my dear sister Marsha. Kelly Kulp, I appreciate your assistance with data wrangling and your willingness to help no matter what the task. I also want to thank the many USF restoration colleagues that I had the pleasure to work with, and especially to those that responded to my survey. Lastly, I want to express my 
gratitude to Dan Halgin and Steve Borgatti, at the University of Kentucky LINKS Center, for taking time to answer questions and helping lead me down the right path. 


\section{Table of Contents}

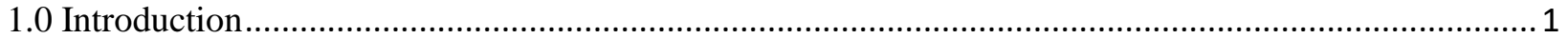

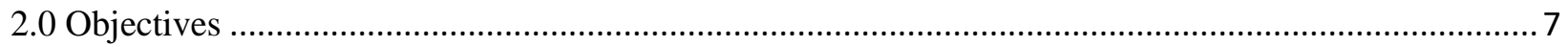

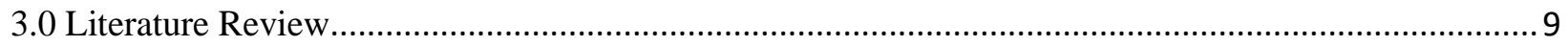

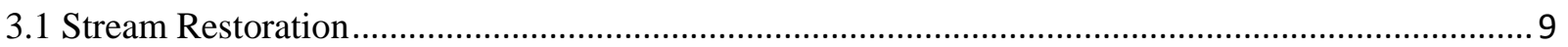

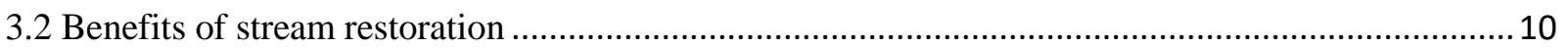

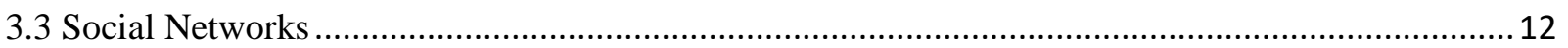

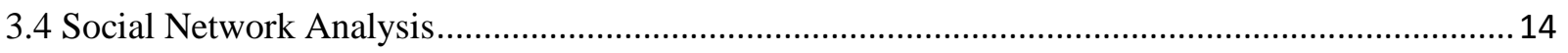

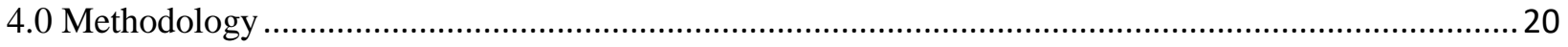

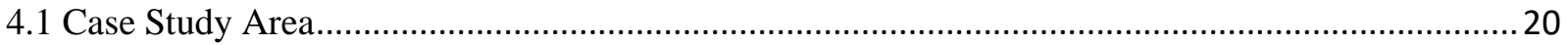

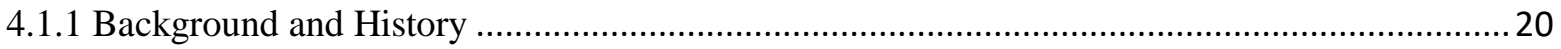

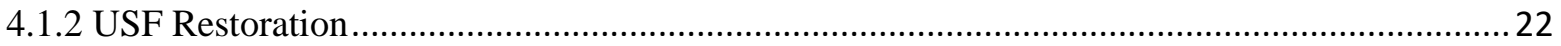

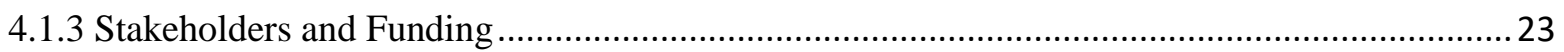

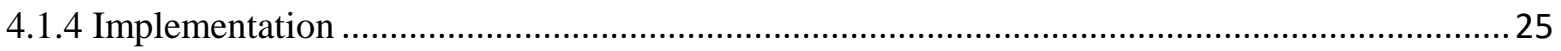

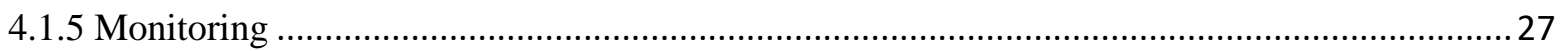

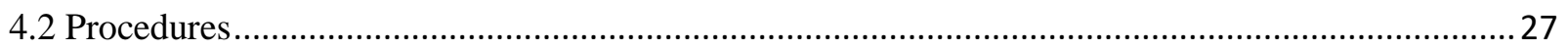

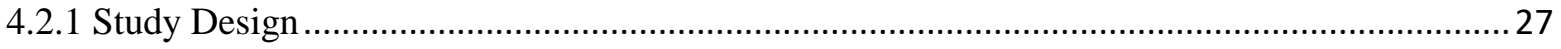

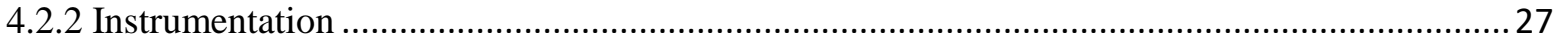

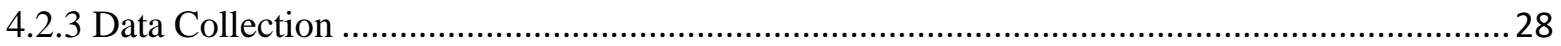

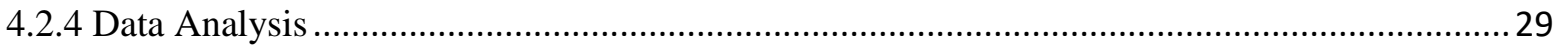

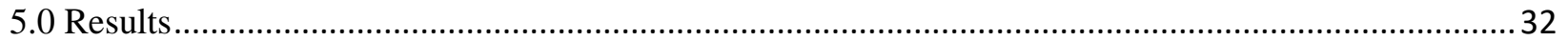

5.1 Research Question \#1: USF Network Structure and Character Evolution......................................32

5.1.1 USF Network Evolution from Before to During Restoration ............................................... 32

5.1.2 USF Network Evolution from During to After Restoration.................................................. 33

5.1.3 Time Independent Comparison to Network Evolution .........................................................33

5.2 Research Question \#2: USF Network Dynamics in Relation to Outcomes ..................................... 34

5.3 Research Question \#3: Impact of Removing Most Central Organizations ....................................35

5.4 Research Question \#4: Potential Future Restoration Network ...................................................... 35

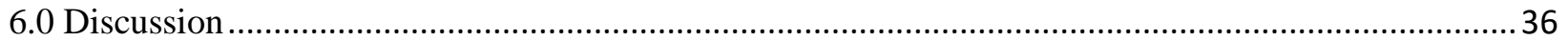

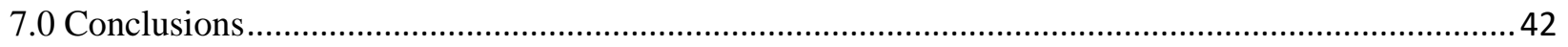

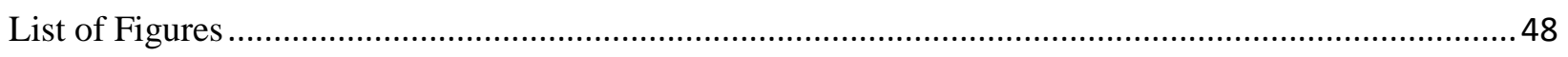

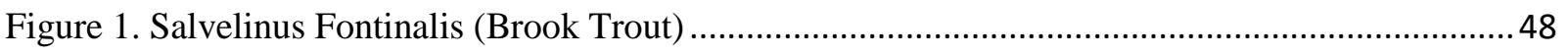

Figure 2. Hypothetical Star Topology - 100\% Network Degree Centralization ...................................49 
Figure 3. Articles with "Social Network" in title indexed in Google Scholar

Figure 4: Idealized Examples of Social Network Structures ...........................................................50

Figure 5. Hypothetical Company Organizational Chart vs. Communication Network Visualization

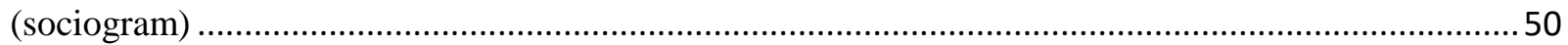

Figure 6. Map of Upper Shaver Fork Watershed .....................................................................51

Figure 7. Historic Photo of Fishermen at Cheat Mountain Club .....................................................5 51

Figure 8. Stakeholders and Partners at Spruce ........................................................................52

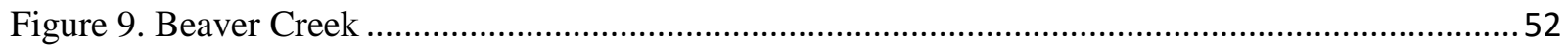

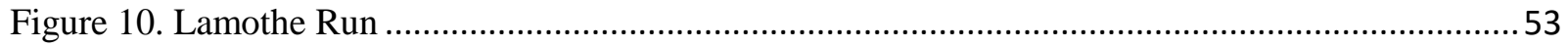

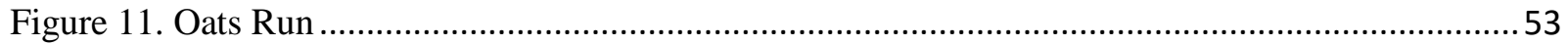

Figure 12. Example Mainstem Restoration Instream Structure (j-hook) ..........................................54

Figure 13. USF Network Respondent Diversity: Professional Background .......................................55

Figure 14. USF Network Respondent Diversity: Education ........................................................5 55

Figure 15. USF Network Respondent Diversity: Age .................................................................56

Figure 16. USF Network Respondent Diversity: Other Conservation Organization Affiliation ............56

Figure 17. Map USF Network Respondent Residence in Proximity to Project Area: (a) Within West

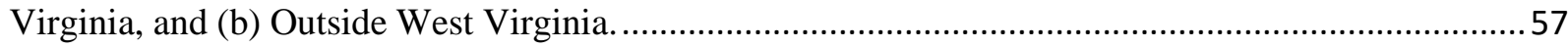

Figure 18. Map of (a) USF Overall and Time Independent Network by Individual Actor and (b) USF Overall and Time Independent Network by Organization................................................................5

Figure 19. Map of (a) USF Network by Individual Actor Before Restoration (2009) and (b) USF Network by Organization Before Restoration (2009) ................................................................59

Figure 20. Map of (a) USF Network by Individual Actor During Restoration (2009-2013) and (b) USF

Network by Organization During Restoration (2009-2013)............................................................60

Figure 21. Map of (a) USF Network by Individual Actor After Restoration (2013-now) and (b) USF

Network by Organization After Restoration (2013-now)...........................................................61

Figure 22. Map of (a) USF Network by Individual Actor Potential Future Collaboration (2017 and beyond) and (b) USF Network by Organization After Restoration (2017 and beyond)......................62

Figure 23. Map of (a) USF Network Before Project with Most Central Actors Removed and (b) USF

Network Before Project with Most Central Organizations Removed................................................63

Figure 24. Hypothetical Clique Topology - 100\% Density and Closure ............................................64

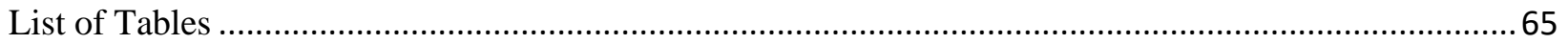

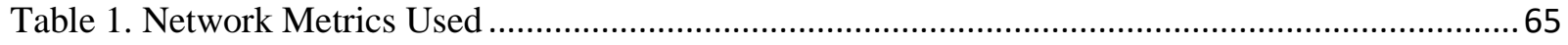

Table 2. Ranking of Most Central Organizations ..........................................................................67

Table 3. Subject Matter Communication/Collaboration Over Time .................................................68

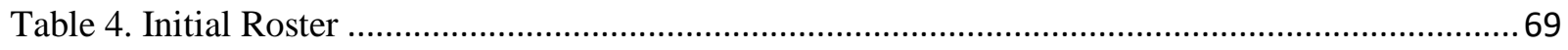




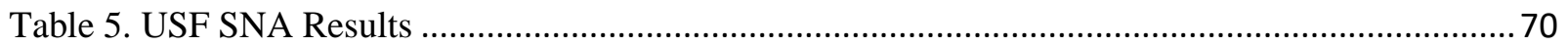

Table 6. USF Network Dynamics in Relation to Outcomes ................................................................ 70

Table 7. Impact of Hypothetically Removing the Most Central Organizations (WVDNR, WVU, and

CVI) from the USF Before Project Network ............................................................................... 70

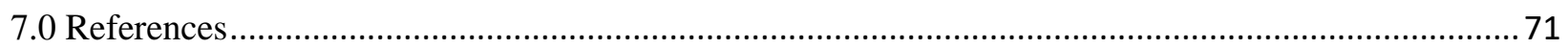

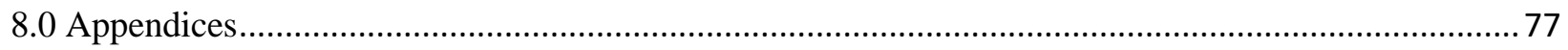

8.1 WVDNR Aquatic Habitat Enhancement Program Plan DRAFT ..................................................77

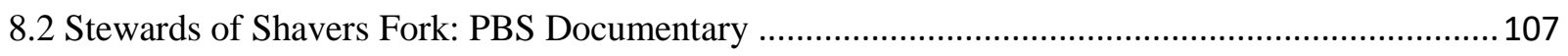

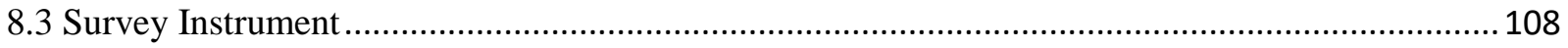

8.4 Highland Adventures of Mountains, Rivers, \& Rail .................................................................117

8.5 Mill Creek, WV Stream Habitat Restoration ......................................................................118 


\subsection{Introduction}

Many prominent earth scientists today suggest that we have entered the Anthropocene, a new geologic epoch of human making that began with the Industrial Revolution a mere two centuries ago (Syvitski, 2012). Human endeavors in agriculture, mining, and urbanization, according to Syvitski (2012) have, "by any unbiased and quantitative measure... affected the surface of the Earth at a magnitude that ice ages have had on our planet, but over a much shorter time" (p. 14). Of course, these major landscape alterations have also caused impairment of, and in many cases utter devastation to, critical ecologies and social capital that comprise complex social-ecological systems (Redman, Grove, \& Kuby, 2004). However, as Syvitski (2012) points out, "the final chapter of the Anthropocene is yet to be written: the narrative will depend on our collective selfawareness and the capacity to correct our course..." The same human capacities for innovation and progress that fueled the industrial revolution, when combined with a spirit of responsibility, may hold promise for a future course of incremental social-ecological systems restoration with globally significant results (Aronson, Milton, \& Blignaut, 2007). Egan, Hjerpe, and Abrams (2011) assert that "a fundamental assumption underlying the concept of ecological restoration is that humans are responsible for degrading the natural environment and, therefore, humans have a responsibility to repair it" (p. 1). Moreover, Aronson, Clewell, Blignaut, and Milton (2006) explain that "faced with ... the mounting number of ecological crises worldwide, ecological restoration clearly has a key role to play in conserving species, and natural capital, and for improving human well-being- both materially and culturally" (p. 136).

The ultimate goal of ecological restoration is to assist in Mother Nature's recovery processes of degraded or destroyed ecosystems (Aronson et al., 2006). The benefits and outcomes of ecological restoration, in terms of increases in biodiversity and ecosystems services, as well as direct 
economic benefits, have been assessed and are well documented (de Groot et al., 2013; Aronson et al., 2010). However, more deeply understanding the human dimensions of ecological restoration may be equally as important. Egan et al. (2011) confirm this notion in the following:

Ecological restoration is a practice of hope: hope because restorationists envision a better future as a result of their efforts. Ecological restoration is a practice of faith: faith because restorationists work in a world of uncertainty. Finally, ecological restoration is a practice of love, love because restorationists care about, and give their lives to, efforts that protect and enhance the lives of humans and other-thanhuman beings alike. Ecological restoration is a human practice, and because it is, people matter (p. 1).

While traditional ecological restoration research continues to be heavily weighted toward distinct measures of bio-physical response and direct socio-economic benefits (jobs, economic development, ecosystem services), modern social-ecological systems research suggests a more integrated perspective of ecological restoration whereby the value of social capital or social networks, in collective planning and action, are also considered (Pretty \& Ward, 2001; Aronson, et al., 2010; McClenachan, Lovell, \& Keaveney, 2015). These social networks support collaboration in a variety of forms including partnerships, co-management arrangements, and adaptive governance systems that exhibit trust, reciprocity in exchanges, and common norms (Pretty \& Ward, 2001). In particular, adaptive natural resource governance systems, as an alternative to top-down government control, rely on social networks that connect individuals, organizations, agencies, and enterprises for collaborative, flexible, and learning-based approaches to managing socio-ecological systems (Olsson, et al., 2006; Sandström \& Rova, 2010). Social networks can also reduce risk in information and resource exchanges (Selin, Pierskalla, Smalldone, \& Robinson, 2007). Mandarano (2009) argues that social networks are the infrastructure of, and an effective means by which to measure, social capital and its benefits. Sandstrom and Rova 
(2010), further suggest that social network structure and dynamics are linked to performance in adaptive natural resource governance, however, empirical evidence remains rare.

Effective adaptive governance is desirable in the sustainable management of ever-changing complex social-ecological systems where "institutional arrangements and ecological knowledge are tested and revised in a dynamic, ongoing, self-organized process of trial and error" (Folke, Hahn, Olsson, \& Norberg, 2005). Perhaps then, insights into the effectiveness of adaptive natural resource governance systems may be gained from better understanding the emergence and structural dynamics of the social networks on which they rely (Crona, \& Hubacek, 2010).

Unfortunately, there are not many better geographies on the planet to witness evidence of an Anthropocene than West Virginia (WV), particularly in the negative impacts of mining, deforestation, acid precipitation, and transportation (road and railroad) development on watersheds and streams. WV streams and watersheds are critical social-ecological systems producing a host of ecosystems services including water supply, food, energy, tourism, and transportation. Many, if not all, are in dire need of some measure of ecological restoration and conservation. Fortunately, for one particular social-ecological system with a rich history, the Upper Shavers Fork, WV (USF), a diversity of stakeholders recognized the need, took responsibility, organized into a form of adaptive governance, and completed a substantial stream and watershed restoration effort. The USF restoration effort was concerned with targeting benefits to brook trout populations while simultaneously enhancing overall watershed health. The brook trout (Figure 1) is the only native trout to WV and represents a key ecological indicator of good water quality as well as overall stream and watershed ecosystem health (Eastern Brook Trout Joint Venture, 2011). 
From many perspectives, the USF four-year restoration effort was a successful demonstration of adaptive governance as evidenced by the following noteworthy outcomes1:

(1) A diversity of stakeholders, from a variety of organizations, formed an adaptive natural resource governance network that achieved agreement on what, where, when, and how to restore an important common pool resource (Sandström \& Rova, 2010);

(2) this network raised approximately $\$ 9$ million from a multiplicity of sources to complete the aforementioned restoration plan;

(3) this network demonstrated flexibility and adaptive capacity in generating solutions to ecological, social, political, and operational challenges (e.g. transition to the use of innovative culvert liners and systems when bridges became unfeasible as well as the unforeseen use of a 100 year old Shay locomotive to deliver restoration materials);

(4) this network completed restoration implementation on schedule, and the physical and hydrogeomorphic efficacy of restoration measures persist today - structures continue to perform as designed and have survived several floods and ice-out events;

(5) this network fostered social learning throughout the effort as witnessed by one of the survey respondents:

I learned a lot on the environmental portion. Starting this project it seemed crazy to spend millions of dollars on fish. We was able to go in to create a better habitat for them to try and help the brooke trout population. The engineering behind it and the procedures in making the steam flow a different direction and to increase the depth of the water. The best part of it for me this was my first supervisor role in my professional career. I didn't know anything about fish habitat but to manage people and to regulate things and to make the process run smooth. We didn't crash the

\footnotetext{
1 Outcomes where derived by reviewing USF steering committee meeting notes, trip reports, progress reports to WVDNR, National Oceanic Atmospheric Administration (NOAA), WV Division of Environmental Protection (WVDEP), and Eastern Brook Trout Joint Venture (EBTJV), survey results, as well as personal observation.
} 
project and we was on budget and at the end we created something to really be proud of which was very rewarding to our crew;

(6) this network achieved technological innovation including the use of airborne/terrestrial lidar and drone-based mapping in planning and monitoring as well as a pioneering effort in the use of baffled-culverts for fish passage in WV, and lastly,

(7) this network represents the genesis of a formal aquatic habitat restoration program at WVDNR and WVU (Appendix 8.1) as well as the publication of a PBS documentary "Stewards of Shavers Fork" (Appendix 8.2).

Of course, this effort began with the explicit goal of producing ecological uplift or "biolift" (i.e. improved ecosystem health and positive biological response) (BenDor, Lester, Livengood, Davis, \& Yonavjak, 2015). As Genskow and Born (2006) point out, however, measurable improvements in environmental quality and ecosystem health resulting from solutions to watershed problems will likely take decades rather than years to manifest. The impairments to USF did not happen overnight, and even with aggressive restoration efforts, biolift may only return slowly. West Virginia University (WVU) scientists are thoroughly monitoring the biological response to USF restoration measures through 2017. In an October 2015 progress report (two year's postrestoration), the WVU Cooperative Fish and Wildlife Research Unit (2015) documented no significant change in brook trout populations with densities remaining near long term averages; however, fish have been observed using restored passage barriers and in-stream habitat structures.

With measurable biolift potentially years away, understanding and documenting nearer term benefits and outcomes of the USF restoration network effort becomes critical. If restoration is measured in ecological response alone, motivation and momentum for additional restoration 
research, education, and implementation may suffer a lack of support. Moreover, adaptive management strategies may be doomed to failure as time erodes interest in and resources to continue experimentation, implementation, and monitoring work on a particular stream or ecological system. So, perhaps then, as ecological systems respond over time to restoration measures, restorationists and stakeholders also respond, but more rapidly, to new patterns of relationships, attitudes, ideas, and behaviors resulting from participation in effective natural resource governance systems and completing substantial restoration projects. This social capital contributes benefits and outcomes and manifests in networks that start to develop even before restoration begins and change in size, structure, and diversity during and after implementation. Moreover, future stream restoration and adaptive management strategies might well depend on the resiliency and sustainability of social networks that were previously established (Crona, \& Hubacek, 2010).

Relationships both enable and constrain, and more importantly, the structure of relationships in social networks can yield insights into power, leadership, innovation, and the ability to mobilize resources and implement change (Borgatti, Brass, \& Halgin, 2014). Furthermore, research by Bodin and Crona (2009) suggests understanding network structure "does make a difference, although the literature on how structural social network characteristics affect natural resource governance is still limited." Incremental and positive steps towards righting the wrongs of the Anthropocene, in WV and beyond, will require momentum and the establishment and sustainability of adaptive natural resource governance systems that are comprised of social networks. The USF restoration effort represents a noteworthy example of a step in the right direction and offers an opportunity to inform future ecological restoration success. 


\subsection{Objectives}

The goal of this dissertation is to understand more fully the effectiveness of the USF adaptive governance system by exploring relationships between the underlying structure and dynamics of the social network and stream restoration effort performance. While there exists theoretical as well as limited empirical evidence that social network structure and character are linked to natural or common pool resource management performance, direct cause/effect relationships remain elusive (Sandström \& Rova, 2010). Moreover, temporal dynamics of network structures further complicate the matter; social networks are not static in nature, which perhaps renders analyses at any given point in time misleading (Angst \& Hirschi, 2016; Stein, Ernstson, \& Barron, 2011). And, while beyond the scope of this research, the challenging question of which is the cause and which the effect still remains. Do social networks produce positive outcomes or do positive outcomes help to build social networks? Mandarano (2009) seems to suggest that social networks may indeed be viewed as both a cause and an effect depending on the circumstance or perhaps the stage of evolution.

More specifically, this dissertation examines social network structures and dynamics in relation to the USF stream restoration efforts by mapping, visualizing, and analyzing the USF restoration network utilizing a social network analysis (SNA) approach. Social network analysis, a wellestablished technique from the social sciences, is used to evaluate structural characteristics and identify network patterns and dynamics (Stein, Ernstson, \& Barron, 2011; Borgatti, Mehra, Brass, \& Labianca, 2009). SNA employs graph theory and sociograms to illuminate network topologies which can provide insights into how individual actors or organizations behave as well as how collaborative efforts function and perform (Bodin, \& Crona, 2009; Barnes-Mauthe et al., 2015). This research employs a retrospective survey methodology and SNA to evaluate the USF network evolution over time (before, during, and after restoration). This evolution in network structure is 
compared to a time independent (static) SNA of the USF network. The impact of removing key central organizations from the USF network before restoration is explored. And lastly, SNA of a potential future restoration network structure and character is conducted.

Hence, this study aims to answer the following questions:

(1) How did USF network structure and character evolve or change over time, and how does this evolution compare to a static or time independent perspective?

Approach: Map, visualize, and compare USF network before, during, and after restoration (Table 1):
a. Size
b. Relationships,
c. Organizations,
d. Cross-Boundary Exchange,
e. Organization Type,
f. Network Degree Centralization,
g. Density,
h. Diameter,
i. Network Betweenness Centrality,
j. Most Central Organizations (Table 2),
k. Subject Matter Collaboration/Communication (Table 3),

and then, compare this evolution to a time independent or static network perspective combining before, during, and after restoration time periods.

(2) How do these social network dynamics relate to USF restoration effort outcomes?

(3) What is the impact of removing the most central organizations from the USF network before restoration?

(4) What is the potential structure and character of a future stream restoration network with its beginnings in the USF restoration effort? 


\subsection{Literature Review}

\subsection{Stream Restoration}

Streams (rivers) are among the world's most vulnerable ecosystems to damage by human activities (Lake, P.S., Bond, N., \& Reich, P., 2007). Streams also have been called the lifeblood of civilization (Rosgen, 1996). This stream/human interaction suggests that streams are also socialecological systems whereby problems should be addressed through a holistic systems perspective toward human and non-human elements (Halliday \& Glaser, 2011). Stream restoration is, then, a type of ecological (or social-ecological) restoration and has become a world-wide phenomenon representing billions of dollars spent in the USA alone (Palmer, et al., 2005). Stream restoration is also highly transdisciplinary (Lake, et al., 2007; Spink, Hillman, Fryirs, Brierly, \& Lloyd, 2010), and according to Rahm, (2002), success requires a great degree of collaboration, diversity of knowledge, and sharing of:

- human resources (leadership and staffing;

- technical resources (knowledge and science application);

- financial resources (grants, donations, and agency funding);

- experiential resources (system knowledge base, expertise, and management);

- structural resources (organizational arrangements, agreements, and contracts);

- legitimacy resources (efforts represent stakeholder will), and

- network resources (relationships between and among stakeholders).

As with ecological restoration in general, stream restoration is often viewed as an adaptive management process whereby restoration measures allow for experimentation and learning in the enhancement of ecosystem structure and function (Petty \& Meriam, 2012; Lake et al., 2007). Every stream restoration endeavor offers a unique set of opportunities and challenges. While restorationists strive to minimize failure, they also use it to learn and adapt methods and 
technologies that re-establish "pre-disturbance aquatic functions and related physical, chemical, and biological characteristics" (National Research Council, 1992). Biolift may best be described by Phillips (2003) in stating that "the ultimate goal of stream restoration is to improve water quality, in-stream habitat, and riparian habitat such that biotic integrity of the stream is improved, approaching the original undisturbed condition" (p. 1). Beyond achieving this goal of biolift, Palmer, et al. (2005) suggests that "projects that satisfy stakeholder needs and advance the science and practice of river restoration (learning success) could also be [considered] ecological successes" (p. 209).

Stream restoration projects are often localized, small-scale projects that focus on channel geomorphology, riparian zone integrity, and floodplain connections; however, they may also include larger watershed or catchment level activities that address land use (Lake, et al., 2007, Rosgen, 1996). While there is a plethora of potential stream restoration practices, Petty and Meriam (2012) suggest those for indicator species such as the brook trout in WV are categorized as follows:

- Species re-introduction;

- Control of fishing related mortality;

- Stream channel restoration;

- Limestone sand application;

- Riparian zone management (temperature and erosion management);

- Dispersal barrier removal, and

- Watershed reforestation.

\subsection{Benefits of stream restoration}

The physical and ecological benefits of stream restoration are many including increased diversity and sustainability of fish and wildlife populations, improved aesthetics, and climate change 
resiliency (Seavy et al., 2009; Ortega, \& Ulgiati, 2004). The socio-economic benefits of stream restoration are also many and can be direct in nature (increases in jobs, ecosystems goods and services, and economic development) or indirect in nature (enhancements to social, cultural, psychological, and spiritual dimensions of human welfare) (Aronson, et al., 2006). The economic value of stream restoration has been well documented by economists such as in the case of Deckers Creek, WV (Collins, Rosenberger, \& Fletcher, 2005). Jobs and other direct benefits of restoration have been shown to increase dramatically over the past decade with ecological restoration job creation significantly outpacing that of traditional U.S. industries such as iron/steel manufacturing, coal mining, and logging (Bendor, et al., 2015). While economic approaches have been used to effectively capture market, and in many cases, non-market, restoration values, there are social benefits and outcomes that arguably fall outside the economic system (Collins et al., 2005; Petursdottir, Arnalds, Baker, Montanarella \& Aradottir, 2013; McClenachan et al., 2015; Ortega, \& Ulgiati, 2004) and are often underestimated, if not excluded (Sprink, et al., 2010).

Social capital is an important benefit and outcome of stream restoration that is often overlooked (Philip, R., \& Beeckie, T., 2013). Spink, et al. (2010) explain that stream restoration is "as much a social undertaking as an environmental one" (p. 399), and is "not just the achievement of improved river condition or health, but also the initiation and strengthening of social networks (p. 407). Social capital in stream restoration has the potential to increase collective action and success (Prell, et al., 2009) as well as a tendency to generate momentum or motivation for additional sustainable restoration and management; (Philip, R., \& Beeckie, T., 2013; McClenachan et al., 2015). Social capital, according to Mandarano (2009), is a model whereby "civic engagement begets new relationships, new relationships lead to greater trust, and trust leads to more effective collective action as well as individual and social benefits." 
Another derivative benefit of stream restoration is in the emergence and strengthening of adaptive natural resource governance that "brings together groups of stakeholders undertaking ecological interventions on an experimental basis and accumulating information towards enhanced ecosystems resilience" (Hodge, \& Adams, 2016). Adaptive governance is an alternative to topdown and centralized management approaches that often fail when confronted with complexities and dynamics inherent to social-ecological systems (Hodge, \& Adams, 2016). Adaptive governance relies on leadership, social networks, and "polycentric institutional arrangements that are nested, quasi-autonomous decision-making units operating at multiple scales" (Olsson, et al., 2006). Adaptive governance systems emerge and transform in response to ecosystem uncertainties as well as unpredictable feedbacks between social and ecological system components (Olsson, et al.; Hodge, \& Adams, 2016).

\subsection{Social Networks}

"It's not what you know; it is who you know"

- Anonymous, 1918

Social networks are the infrastructure of social capital (Mandarano, 2009), and according to Barnes-Mauthe, Gray, Arita, Lynham, and Leung (2015), "social networks, and the patterns of relationships between individuals and groups they comprise, are intimately tied to the notion of social capital (p. 392). Burt (1992) maintains that social capital (an actor's relationships to other actors) is distinct from other types of capital such as financial capital (cash, bank reserves, lines of credit) and human capital (charm, intelligence, looks, heath). Lin (1999) suggests a simple 
definition of social networks as "investment in social relationships with expected returns." Hence, social networks are social capital.

Embedded in social networks are social bonds (trust, reciprocity, common norms) and resources (flows and exchanges of information, funding, and expertise) that can promote individual or collective gain (Barnes-Mauthe et al., 2015; Pretty, \& Hugh, 2001; Lin, 1999; Timur, \& Getz, 2008). Social networks are comprised of "actors" (individuals or groups) and "ties" which are relationships between actors that represent the nature and degree of connectedness and resource/information exchange (Timur, \& Getz, 2008; Pretty, \& Ward, 2001).

Social networks have structure and character, such as density (number of ties) and centralization (presence or absence of central actor(s)) that offer insight into the motivations for and performance of collaborative efforts and collective action (Barnes-Mauthe et al., 2015; Prell et al., 2009; Timur, $\&$ Getz, 2008). Social networks of high density result in more efficient communication and facilitate opportunities for joint action and conflict resolution (Bodin, \& Crona, 2009; Timur, \& Getz, 2008). Whereas, a network with high centralization is one with only a few actors holding ties to the overall network (Figure 2), and although this high degree of centrality has been shown to help in mobilization and coordination of initial collaborative effort, less centralized networks are likely favored for long term sustainability of effort, particularly in solving problems within complex ecosystems (Prell et al., 2009; Bodin, \& Crona, 2009).

Below the overall structure of social networks there exist types and attributes of ties and actors. There are strong and weak ties. Strong ties, often referred to as bonding ties, promote communication, social learning, development of common norms and trust; however, overtime, they can result in redundancy of information and stagnation in innovation (Fischer, VanceBorland, Jasny, Grimm, \& Charnley, 2016; Prell et al., 2009). Weak ties, or bridging ties, stimulate 
the formation of new ideas, offer access to a diversity of resources, and facilitate complex problem solving (Bodin, \& Crona, 2009; Fischer, et al., 2016). Attributes of network actors can influence relationships and connectivity while the position of actors within the network can impact resource and information exchange (Prell, et al., 2009). Actors demonstrating homophily tend to associate and bond with others that are similar which can promote mutual understanding and complex information exchange; however, this can also be detrimental, limiting diversity and frustrating innovation and adaptive capacity (Prell, et al., 2009; Bodin, \& Crona, 2009). In addition to overall network centralization described above, actor centrality is determined by their position in the network. Actors with high degree centrality hold positions with large numbers of strong ties to other actors and generally promote information dissemination, trust, and mobilization to action, whereas, those with high betweenness centrality hold positions between otherwise disconnected actors (weak ties) and serve as brokers bringing diversity and innovation to the overall network (Burt, 2000; Granovetter, 1973; Prell, et al., 2009; Borgatti, et al., 2009).

\subsection{Social Network Analysis}

Social Network Analysis (SNA) is a well-proven quantitative methodology for the measurement, visualization, and analysis of social relationship structures and characteristics (Borgatti, et al., 2009; Barnes-Mauthe, et al., 2015). SNA has deep roots in the social sciences dating back to the early 1800 with social philosopher Comte pioneering a new field of "social physics" (Borgatti, et al., 2009). In 1932, Moreno's famous use of "sociometry" (a precursor to modern SNA) produced successful modeling results of social influence and mutual attraction among Hudson School for Girls runaways in New York which inspired further advancements in SNA during the 1950's including the use of matrix algebra and graph theory (Granovetter, 1973; Borgatti, et al., 2009). Today, Borgatti and Halgin (2011) illustrate in Figure 3 that publications referencing "social 
networks" have seen exponential growth since the beginning of this century with interests expanding beyond the social sciences to physics, biology, and other physical sciences.

Modern SNA is grounded in well-established social network theory. Broadly, this body of theory offers solutions to fundamental weaknesses in traditional sociological theory by accommodating an explanatory bridging of micro-level behaviors (e.g. individual choice, small group dynamics) with macro-level patterns (e.g. social mobility, community development, political structure)(Coleman, 1988; Granovetter, 1973). Moreover, the social network theory behind SNA, blends components from two intellectual streams of thought that often arrive at competing descriptions and explanations of social action (Coleman, 1988). Coleman (1988) contrasts these two intellectual streams of thought:

One, characteristic of the work of most sociologists, sees the actor as socialized and action as governed by social norms, rules, and obligations. The principal virtues of this intellectual stream lie in its ability to describe action in a social context...The other intellectual stream, characteristic of the work of most economists, sees the actor as having goals independently arrived at, as acting independently, and as wholly self-interested. Its principal virtue lies in having a principle of action, that of maximizing utility (p. 95).

There exist a variety of historic influences on social network theory; however there are three wellknown traditions underpinning modern SNA that are most germane to this research: (1) Granovetter's (1973) strength of weak ties theory (SWT); (2) Coleman's (1988) network closure theory (NC), and (3) Burt's (1992) structural holes theory (SH) (Borgatti, \& Halgin, 2011). The first premise of SWT is that tie strength is a function of the duration/intensity of the relationship (i.e. amount of time spent together, emotional investment, intimacy, and/or reciprocity in resource exchange) (Granovetter, 1973). This, along with people's tendency toward homophily, suggests actors with strong ties have a high degree of overlap in their social worlds (i.e. they will have ties to the same third parties) (Borgatti, \& Halgin, 2011; Ganovetter, 1973). SWT, theorizes then that 
strong ties result in redundancy of information exchange and stifle growth and innovation (Granovetter, 1973, Burt, 1992). Weak ties, on the other hand, are bridging ties that promote the exchange of novel information; hence, people with more weak ties tend to be more successful (Borgatti, \& Halgin, 2011).

In nearly direct opposition to SWT, Coleman (1988) argues that NC (i.e. many strong ties) fosters the development of trust, social obligations and expectations, channels of rapid information exchange, and social norms. NC postulates that dense networks promote collective action and collaboration; and thus, generally increase performance (Burt, 2000). In contrast with NC, Burt's (1992) SH theory aligns closely with SWT arriving at the same general conclusions from a slightly different perspective. SH theory states that there are clearly advantages to more open network structures in much the same manner as SWT; however, Burt (1992) explains "the weak-tie argument is simpler than my argument...the causal agent in the phenomena is not the weakness of the tie but the structural hole it spans. Tie weakness is a correlate, not a cause." (p. 73). Burt (2000) then proceeds to integrate SH with NC realizing perhaps the optimal network structure has properties of both whereby structural holes are a source of novel information while network closure capitalizes on the values buried in those holes.

Dyadic and triadic relationships aggregate into broader social networks with measurable properties and structures (Coleman 1988; Borgatti, \& Halgin, 2011). Borgatti and Halgin (2011) explain "much of the theoretical wealth of network analysis consists of characterizing network structures (e.g. small-worldness) and node position (e.g. centrality) and relating these to group and node outcomes" (p. 2). Idealized network structures (Figure 4) such as diffuse, core-periphery, and clique (small-world) offer insights into generalized network character (Borgatti et al., 2013). More diffuse network structures have global homogeneity and local diversity that facilitate knowledge 
sharing, incremental innovation, and individual creativity (Halgin, \& Brass, 2016; Borgatti et al., 2013). Core-periphery structures tend to have central homogeneity and peripheral diversity capitalizing on novel information from the periphery while simultaneously fostering collective action and efficient problem solving in the core (Prell et al., 2009; Bodin, \& Crona, 2009). Coreperiphery structures are however vulnerable to the loss of key actors in the core and may be less sustainable over time (Prell et al., 2009; Bodin, \& Crona, 2009). Clique structures have global diversity and local homogeneity which can frustrate cooperation and information dissemination, but can lead to radical innovation (Halgin, \& Brass, 2016; Borgatti et al., 2013).

Social network data are collected in a variety of ways including historical records, enthographic studies, document analyses, interviews, and/or surveys (Borgatti, et al., 2013). These data can represent relationships (e.g. coworker, father, partner, friend), communication (e.g. seeks advice from, gives advice to), flows of resources (e.g. funding, expertise, materials), or collaboration (e.g. works with, learns from) among network actors. Once collected, network data are generally arranged in a one-mode dataset or adjacency matrix where the rows and columns are the same (Borgatti, et al., 2013). Matrices are then visualized as sociograms and/or analyzed as mathematical structures employing graph theory to model pairwise relationships between objects or actors. Figure 5 provides an example of the difference between a hypothetical organizational chart versus the company's true communication network derived from an adjacency matrix of employee interview responses (Cross, Parker, Prusak, \& Borgatti, 2001). The typical hypothetical organizational chart suggests a very different, if not misleading, perspective on who has power and influence in the organization as compared to the social network sociogram visualization. For instance, one might think that Cole is far down in the ranks with little power and influence from 
looking at the organizational chart; however, he is revealed to be a key information broker in a social network view of the organization.

While there are many quantitative network measures for whole networks and individual actor networks (ego networks), Bodin et al. (2006) offers four measures important for social networks in natural resource management. These quantitative network measures are density, reachability, degree centrality, and betweenness centrality and can be readily calculated in a variety of SNA software packages including UCInet (Bodin, et al., 2006; Borgatti, et al., 2013; Borgatti et al., 2002). Density is the number of ties divided by number of nodes (a type of network closure), reachability is diameter or the maximum number of steps to reach from one node to any other node, degree centrality is the number of ties for each node, and betweenness centrality is the number of shortest paths from all nodes to all others that pass through that node (Bodin, et al, 2006; Borgatti et al., 2013). Angst and Hirschi (2016) also offer transitive closure (bonding social capital) as a fifth important measure of social networks in natural resource management, particularly in evaluating network changes over time. Angst and Hirschi (2016) empirically test the theory that natural resource governance networks tend to decrease in centrality and increase in closure as they mature.

SNA has many and widespread applications. For instance, businesses use SNA to analyze and improve communications, marketing, and workflow, law enforcement and military organizations use SNA to crack criminal and terrorist networks, social media sites such as Facebook use basic elements of SNA, and communications companies use SNA-like methods to optimize structure and capacity of telephone, cable, and mobile communication networks (Cheliotis, 2006). While direct SNA in empirical stream restoration research appears to be quite limited, scholars analyzing natural resource management and governance issues, in general, have begun to adopt social 
network approaches (Barnes-Mauthe, et al., 2015). Moreover, SNA is becoming more popular in social-ecological systems and adaptive governance research as in the case of rainwater management system development in context of stakeholder experience in Ethiopia (Prager, \& Pfeifer, 2015). Furthermore, Fliervoet, et al. (2016) used SNA in a case study of river management in the Netherlands to analyze conflicting uses of floodplains where stakeholder groups divided along the lines of "nature" and "flood protection" motivations. A Kenyan fishing community network was investigated by Bodin and Crona (2008) using SNA to explore deficiencies in social capital leading to over-exploitation of fisheries. Stein, et al. (2011) used SNA to "empirically map collaborative social networks between actors that either directly or indirectly influence water flows in the Mkindo catchment in Tanzania" (p. 1085). 


\subsection{Methodology}

\subsection{Case Study Area}

\subsubsection{Background and History}

"Had a royal good time and caught barrels of fish."

- Unidentified Angler, 1903

Understanding river evolution and environmental history is key in guiding effective restoration and management practices (Spink et al., 2010). To appreciate the USF, a tributary of the Cheat River, WV (Figure 6), as a social-ecological system in need of restoration, one must first understand its rich history and the human influences that caused its degradation. In the late $19^{\text {th }}$ and early $20^{\text {th }}$ centuries, visitors flocked to the USF which was considered to be one of the premier brook trout fisheries in the eastern United States (Brown, 2014). Entries in the log book of the Sportsmen's Association of Cheat Mountain (now kept under close guard at the Cheat Mountain Club near Cheat Bridge, WV) record famous visitors such as Henry Ford, Thomas Edison, Harvey Firestone, and John Burroughs and incredible stories of 300 trout per day catches of fish (Figure 7), some exceeding 14 inches in length (S. Brown, personal communication, February 9, 2016).

Such a high quality trout stream was the result of a pristine watershed with an abundant virgin red spruce forest. This forest provided slow and consistent runoff of cool, clean water year round and a source of large woody debris habitat creating ideal conditions for brook trout. However, this forest also became recognized in the early $20^{\text {th }}$ century as an extremely valuable timber resource. Red spruce is light weight and very strong which made it highly sought after for producing paper, pulp, and lumber for construction material including components of the Wright brother's first airplane (Clarkson, 1990). 
Loggers first tried to use the USF as a means to transport (float) logs out of the very remote geography. Boulders were blasted and removed from the river to facilitate log drives which proved unsuccessful, and ultimately, destroyed important fish habitat as well as increased riparian damages from annual ice scour (Clarkson 1990; S. Brown, personal communication, January 5, 2016). Between 1899 and 1904, a logging railroad was constructed along Upper Shavers Fork to facilitate timber harvest, and by 1904, the town of Spruce (elevation 3853ft) sprang up near the top of the watershed 24 miles upstream of Cheat Bridge (Brown, 2014; Clarkson, 1990). The USF watershed was clear cut with most of the virgin red spruce removed by 1936; the town of Spruce, once boasting a population of 350, was deserted by 1950 (Clarkson, 1990). Following the railroad development and deforestation, the aquatic habitat and water quality deteriorated causing such substantial declines in native brook trout abundance, that the Sportsmen's Association of Cheat Mountain convinced the U.S. Fish Commission to begin stocking Upper Shavers Fork with rainbow trout (S. Brown, personal communication, January 5, 2016). While the railroad development and logging operations severely impacted Upper Shavers Fork by severing tributaries from the mainstem (fish dispersal barriers), facilitating water temperature and sediment increases, and removing instream habitat, acid precipitation, largely from coal-fired power generation to the west, degraded water quality to a point in which the river could barely sustain life by middle $20^{\text {th }}$ century (Clarkson, 1990; Brown, 2014).

Today the forest of USF watershed has returned; a thriving mixed mesophytic forest has largely replaced the red spruce. It is a beautiful and remote watershed with very little resident human population. There are less than 50 residents at Cheat Bridge, and although Snowshoe Resort receives approximately 500,000 visitors per year, the permanent residency within the watershed is only a few individuals. The majority of the 60 square mile drainage area of USF is now in public 
ownership. United States Forest Service, Monongahela National Forest comprises the largest ownership with the West Virginia State Rail Authority owning most of the rail and stream corridor. Outside of fishing, USF offers a host of recreational opportunities in hiking, hunting, camping, swimming, boating, skiing, and scenic rail tourism. Game, timber, water supply, forest carbon sink, and remote tranquility are among the watershed's current ecosystem services. Despite public management and time to heal, the USF needed restoration.

\subsubsection{USF Restoration}

In the early 1990's, the West Virginia Division of Natural Resources (WVDNR), began successful mitigation of stream acidification in USF by introducing annual application of limestone sands. This achievement sparked momentum and interest in further and more holistic restoration of the watershed and trout fishery among resource managers and academics, and thus, prompted WVDNR to fund a decade of USF research at WVU. Brown (2014) explains that WVU fisheries professor Dr. Todd Petty and students conducted such an extensive research agenda into the dynamics of the fishery and factors that limit its recovery that USF is one of the most studied rivers in WV. To address remaining limiting factors such as poor channel morphology, stream bank instability, insufficient forested riparia, excessive temperatures, severed tributaries, and poor habitat diversity, WVDNR and WVU forged a stream restoration partnership. Petty (2012) described the first partnership step: "in the upper Shavers Fork, we have designed a brook trout restoration strategy that combines: 1 - acid remediation, 2 - culvert replacement, 3 - in-stream and riparian habitat enhancement, and 4 - angler harvest restrictions in an effort to address multiple limiting factors operating in different areas of the watershed."

Such an ambitious strategy required more collaborators, planning, technology, and funding. In 2009, the WVU Natural Resource Analysis Center (NRAC) was tasked with developing and 
employing state-of-the-art technologies in remote sensing, Geographic Information Systems (GIS), and data collection to further assess the USF. The watershed was flown with airborne Lidar data at a one-meter post-spacing to yield high resolution digital elevation models to be used in GIS analyses and development of contour and hill-shaded relief maps. Terrestrial Lidar was utilized to develop 3D models in points of interests such as hanging or crushed culverts. The Lidar data proved extremely valuable in assessing a variety of geomorphic variables over a large area including valley form, floodplain character, channel width, stream sinuosity, forest canopy, and in-stream structure. Drones were used to capture airborne videography and photography and experiments are still ongoing in using drone-based thermal imagery to map stream surface temperatures. Total station surveys were conducted to assess bankfull stream dimension, pattern, and profile to be used in conjunction with pebble counts to quantify sediment movements and to classify stream reaches (Rosgen, 1996). Stream reference reaches (reaches of high quality habitat) were also identified, surveyed, and documented. Large volumes of geographic, hydrologic, geomorphic, and biological data where integrated in the planning process for restoration actions. Candidate technologies for culvert replacement and instream and riparian habitat enhancement were evaluated.

\subsubsection{Stakeholders and Funding} Also in 2009, the WVDNR-WVU team began the outreach process to identify and engage stakeholders as well as to seek funding for restoration. Canaan Valley Institute (CVI), a non-profit, local stakeholder driven organization, possessed strong skills and experience in natural stream restoration planning, design, and implementation in WV. For this reason, the WVDNR-WVU team executed a consulting agreement with CVI. A steering committee was formed representing key collaborators from the WV State Rail Authority, Snowshoe Resort, U.S. Forest (USFS) Service, U.S. Fish and Wildlife Service (USFWS), Trout Unlimited (TU), U.S. Natural Resource 
Conservation Service (NRCS), Tygart Valley Conservation District (TVCD), Shavers Fork Coalition, and of course, WVDNR, WVU, and CVI. While very few people live in the USF watershed, it was not long until a comprehensive list of stakeholders for this social-ecological system were identified and engaged (Table 4; Figure 8). WVDNR-WVU, along with CVI, made dozens of trips up the tracks in hi-rail trucks seeking input from a host of stakeholders. The initial restoration strategy slowly began taking form into site-specific conceptual plans. Field trips, maps, data, and dozens of facilitated meetings with collaborators and stakeholders turned conflict into compromise, and ultimately, a multi-faceted plan for riparian, mainstem, tributary, and forest restoration, benefiting at least 12 stream miles, emerged.

With stakeholder buy-in, plans drafted, and collaborators secured, how would this major effort be funded? First, WVDNR-WVU-CVI engaged Congressman Alan B. Mollohan of the WV first congressional district. Mr. Mollohan was a strong supporter of ecological restoration in WV, and also an avid fisherman. After perusing the plans, and several field trips up the tracks with his staff, Mr. Mollohan secured an earmark from the committee to which he was chair, Commerce, Justice, and Science, to support the effort. Next, through coordination with NRCS, and again, many field trips and meetings, the WVDNR-WVU-CVI triad persuaded TVCD to apply compensatory mitigation funds from their nearby Elkwater impoundment construction that destroyed a mile of brook trout habitat toward USF. The Eastern Brook Trout Joint Venture (EBTJV), part of the National Fish Habitat Program, granted project funding, and the WV In-Lieu Fee Mitigation Program released funds to support the effort as well. By the time of implementation, it was clear to the WVDNR-WVU-CVI triad that the consideration of the human dimensions in restoring USF were as significant, if not more, than the initial scientific assessments and technology applications. More accurately, these seemingly distinct social-ecological components where integrated each 
supporting the other for sound solutions in good science that not only garnered stakeholder and collaborator support, but fueled momentum.

\subsubsection{Implementation}

State-of-the-art natural stream restoration and culvert replacement on USF began in 2010. Characteristics of natural, stable, and biologically functional stream reaches were used to design and implement restoration of selected impaired reaches and tributaries with aquatic passage barriers. The overall restoration strategy combined with stakeholder input drove the following restoration techniques:

- Stream bank stabilization to reduce sedimentation and riparian vegetation and tree planting for bank stability and shade for maintaining cooler stream temperatures

- Construction of large rock and wood-based instream structures to improve and maintain channel morphology and function as well as to enhance brook trout habitat (j-hooks, crossvanes, wing-deflectors, toe-wood, mud-sills, and revetments)

- Culvert replacement and/or modification with baffled culverts (simulated stream bed) to reconnect severed tributary spawning habitat and access to cold water refugia

- Watershed spruce forest restoration

- Suspension of trout stocking above Beaver Creek until a 5 year monitoring effort can be completed and reviewed in 2017 (harvest restrictions and regulations will be discussed at that time as well)

Three successful tributary fish passage barrier removal projects were completed at Beaver Creek (Figure 9), Lamothe Run (Figure 10), and Oats Run (Figure 11) where there existed an abundant population of isolated brook trout. These passage barrier removal projects essentially bookended (upstream and downstream) the 4 miles of instream structure development and habitat 
enhancement on the Shavers Fork mainstem (Figure 12). At Beaver Creek, a crushed culvert was excavated from under the railroad and replaced with three large culverts designed to handle flows exceeding a 100 year flood event. The center culvert is $10 \mathrm{ft}$ in diameter, and a baffled and simulated stream bed was developed through its length. Step pool structures were constructed above and below the culvert to facilitate aquatic passage with a particular emphasis on brook trout (no more than a 6 inch jump). Lamothe Run had a crushed and hanging culvert under railroad grade which was also excavated and replaced with a WVDNR-WVU-CVI designed baffled culvert system with two flood overflows. This baffled culvert system was designed to facilitate fish passage through a series of notched baffles or steps with slack water resting zones. Eventually, these steps will fill with native rock and sediment and serve as a simulated stream channel. An old stream channel was reclaimed with step pool structures constructed above the baffled culvert at Lamothe Run. Lastly, at Oats Run, a tributary in the vicinity of the ghost town at Spruce, a 100ft culvert was retrofitted with a WVDNR-WVU-CVI designed baffled liner and grouted into place. Brook trout could leave Oats Run before the retrofit, but could not return through the long $100 \mathrm{ft}$ run of swift water through the pipe. In an ironic twist, century old Shay locomotives from Cass Scenic Railroad State Park were used to deliver the massive baffled culvert systems to both Lamothe and Oats run. The main rail line from Cheat Bridge was not accessible due to the instream restoration work by TVCD; hence, the same old coal-fired steam locomotives used in the early $20^{\text {th }}$ century in the devastation of USF watershed, came to the rescue as a critical part of this $21^{\text {st }}$ century restoration. The WVDNR Director at that time, Frank Jezioro, excitedly commented on the effort "for the first time in twenty-five years, brook trout in the Shavers Fork mainstem can move upstream in Beaver Creek and other critical spawning areas" (S. Brown, personal communication, February 9, 2016). 


\subsubsection{Monitoring}

The physical and hydro-geomorphic efficacy of the restoration structures and culvert systems are monitored bi-annually for lessons learned and permit compliance. To date, all restoration practices are performing as designed and constructed. The mainstem and tributary projects have experienced several bankfull and two flood events over the last five years without failure. The biologic response, with an emphasis on brook trout population, size of individuals, and mobility, is being monitored annually by WVU in a long term evaluation study to be completed in 2017 . In an October 2015 progress report (2 years' post-restoration), the WV Cooperative Fish and Wildlife Research Unit (2015) documented no significant change in brook trout populations with densities remaining near long term averages; yet, fish were observed using restoration structures.

\subsection{Procedures}

\subsubsection{Study Design}

This research utilized an embedded case study approach that afforded an opportunity for "Reflexive engagement in wicked problems [which] closes the gap between research and practice, increasing potential for knowledge sharing" (Dredge, Hales, \& Jamal, 2013). The author was highly engaged in USF restoration effort from the beginning, serving as a central actor in the network. The author had previous experience working as an employee for WVDNR and CVI, and is now a WVU researcher. The author's role in the USF fork restoration effort was in comanagement and coordination with stakeholders in the planning, funding, implementation, and monitoring of watershed and stream restoration. This research study is also retrospective and was not conceived until after USF restoration implementation in 2013.

\subsubsection{Instrumentation}

A survey instrument was developed using Qualtrics software and was approved by the WVU IRB September 17, 2016 (Appendix 8.3). This survey instrument was web-based and completed electronically beginning October 1, 2016 by individuals (stakeholders) involved in USF stream 
and watershed restoration (Table 4). Phone and/or in-person interviews were conducted with those unable or unwilling to complete the survey electronically. Data collection continued until November 1, 2016. Network survey questions were administered by roster to maximize recall (Borgatti, Everett, \& Johnson, 2013). The initial roster was developed by reviewing USF steering committee meeting notes, trip reports, and progress reports to WVDNR, National Oceanic Atmospheric Administration (NOAA), WV Division of Environmental Protection (WVDEP), and Eastern Brook Trout Joint Venture (EBTJV) as well as personal communication. In a mixed method approach, snowball sampling, a well-established qualitative research methodology, was also used to identify stakeholders that may have been overlooked in the initial roster (Noy, 2008). Where possible, those left out were offered an opportunity to complete the electronic survey or participate in an in-person/phone interview.

\subsubsection{Data Collection}

Respondents were queried about their level of interaction with other stakeholders relating to the USF stream and watershed restoration effort over the past 10 years (before, during, after, and anticipated future restoration collaboration) as well as non-network questions relating to individual attributes and opinions. Specifically, they were asked how often they communicated and/or coordinated with others regarding the USF restoration in (1) planning/coordination, (2) funding, (3) construction/implementation work, (4) bio-physical monitoring, and (5) outreach/education (Fischer et al., 2016). Questions were categorical in nature (e.g. How often did you interact with each of the actors you listed during the USF restoration project? - once, daily, weekly, monthly, yearly (Borgatti, Everett, \& Johnson, 2013). 59 of the 95 targeted stakeholders completed the survey yielding a response rate of $62.1 \%$. 16 additional stakeholders that were missed in the initial roster where identified, and only one of which completed the survey. Network information about actor (stakeholder, organization) attributes and ties (i.e., relationships, interactions) were compiled 
as network data in SNA (Fischer et al., 2016). One-mode adjacency matrices where developed for the overall network independent of time as well as for before, during, after, and future time frames. Two-mode actor/attribute matrices were also developed.

\subsubsection{Data Analysis}

UCInet 6 for Windows was used to perform SNA on USF network data (Borgatti, Everett, \& Freeman, 2002). The first step was to map, visualize, and analyze the USF network by individual actors and organizations before, during, and after restoration time frames as well as for an overall time independent network (combining before, during, and after) and a potential future network. Embedded in the size, structure, and diversity of the USF network is the social capital that emerged and/or was enhanced by virtue of participation in the USF restoration effort. To address respondent recall challenges inherent to a retrospective survey approach, network data were simplified in the following manner: (1) all USF network analyses were conducted on undirected or symmetric ties (i.e., all ties were considered to be reciprocated between actors), and (2) all ties were dichotomized (i.e., made binary) where "regular" or "frequent" communication/collaboration was coded as one and all others coded as zero (Borgatti, \& Halgin, 2011; Fliervoet, et al., 2016). USF network data were updated with survey respondent attributes including organizational representation, organization type, professional background (Figure 13), education (Figure 14), age (Figure 15), other conservation organization affiliations (Figure 16), and home location (Figure 17).

In the second step, to complement USF network visualizations, key network metrics for natural resource management where calculated including size, relationships, number of organizations, cross-boundary exchange, organization type, network degree centralization, density, reachability, and network betweenness centrality (Table 1). These metrics relate network structure and character to behavior and performance in areas such as social memory, heterogeneity, redundancy, 
learning, adaptive capacity, and trust (Bodin, et. al., 2006; Sandström, \& Rova, 2010). Furthermore, Bodin, et. al. (2006) suggests that these network metrics reflect structural dynamics that may relate to network effectiveness while Angst, \& Hirschi (2016) used network closure and centralization metrics, in a case study of Swiss landscape management, to verifying an expected trend of more bonding social capital in maturing networks while also rejecting the notion that effective networks shift toward more decentralized structures over time. These metrics where then used to evaluate USF network structure and character changes before, during, and after the restoration effort as well as to compare this evolution to an overall time independent network.

In the third step, the top five most central organizations were identified by degree centrality measures for all time periods, and the top three of which were hypothetically removed from the before project time frame for comparison.

The fourth step was to explore performance by relating USF network structure and character dynamics to restoration effort outcomes over time. Presented in the introduction, these outcomes included:

(1) Restoration plan developed;

(2) \$9 million funding secured;

(3) Adaptive capacity demonstrated;

(4) Effective implementation completed;

(5) Social learning transpired;

(6) Technological Innovation materialized, and

(7) Resiliency and momentum realized. 
The last step was to visualize and explore the size, structure, and diversity of a potential future restoration network that may continue work on Shavers Fork as well as other stream restoration projects throughout WV. Again, key network metrics (Table 1) were calculated for the network of anticipated future communication/collaboration. These metrics were also related to USF outcomes in order to evaluate resiliency and momentum and to speculate on future network potential. 


\subsection{Results}

This section presents SNA results and is organized by research question (1) how did USF network structure and character evolve or change over time, and how does this compare to a static or time independent perspective? (2) How do USF social network dynamics relate to restoration effort outcomes? (3) What is the impact of removing the most central organizations from the USF network before restoration? (4) What is the potential structure and character of a future stream restoration network with its beginnings in the USF effort? The SNA results provided here will be interpreted in the following discussion section.

\subsection{Research Question \#1: USF Network Structure and Character Evolution}

Table 5 presents the results of SNA performed on all time periods including an overall time independent network that combined data from before, during, and after the restoration effort depicting network structural dynamics. Table 1 provides a definition and interpretation of 9 key network metrics for natural or common pool resource management/governance that correspond with Table 5 results while two additional network analyses can be found in Table 2 (ranking of most central organizations)2 and Table 3 (subject matter collaboration/communication). Moreover, visualizations of these networks by individual actor and by organization, including an organization type, can be found in Figure 18 (time independent), Figure 19 (before project), Figure 20 (during project), Figure 21 (after project), Figure 22 (future collaboration), and Figure 23 (top 3 central organizations removed).

\subsubsection{USF Network Evolution from Before to During Restoration}

Table 5 illustrates a large USF network size increase from before the project to during restoration, nearly doubling from 55 to 93 actors representing 19 and 38 organizations, respectively. This

${ }_{2}$ Centrality scores were calculated for all organization in Table 5; however, only the ranking top five are included per time period. 
before-to-during USF network size increase was accompanied by an increase in cross-boundary exchange (2.4\%) and organizational diversity as well as a decrease in network centralization (2.1\%) and density (3\%). Network diameter remained unchanged for the before-to-during time step while network betweenness centrality dropped by $11.4 \%$. Communication/collaboration (Table 3) in planning and funding dropped from before-project to during-project time frames while construction/implementation and bio-physical monitoring increased.

\subsubsection{USF Network Evolution from During to After Restoration}

After the restoration project, Table 5 shows a drop in network size to 71 actors and 31 organizations; however, these numbers still remained higher than the before project values. Moreover, one organizational type was lost after the restoration project and network density fell again by nearly $1 \%$. Cross-boundary exchange, network degree centralization, and diameter all increased above the values before restoration. After restoration, network betweenness centrality increased over the during restoration level, but remained lower than before restoration. Communication/collaboration (Table 3) in planning, funding, and construction/implementation all decreased after restoration while bio-physical monitoring and outreach/education increased.

\subsubsection{Time Independent Comparison to Network Evolution}

The results for the USF time independent network are also presented in Table 5. In comparing results of USF network dynamics to the time independent network, it is not surprising that the size, number of relationships, and number of organizations are greater in the time independent network given that this is a combination before, during, and after time periods. Cross-boundary exchange in the time independent network is higher than before and during networks, but lower than after restoration. All 9 organizational types are represented in the time independent network. This network is more centralized when compared to other time periods. The time independent network density is higher than during or after restoration, but lower than before restoration. The diameter 
of the time independent network is lower than after the restoration effort while its betweenness centrality is only greater than the during restoration time frame. Figure 13, Figure 14, Figure 15, and Figure 16 show USF time independent network respondent diversity attributes: professional background, education, age, and other conservation organization affiliation, respectively. Figure 17 illustrates USF overall time independent network respondent residences in proximity to the watershed.

\subsection{Research Question \#2: USF Network Dynamics in Relation to Outcomes}

Table 6 presents the relationship between USF network dynamics and restoration effort outcomes and was produced from a combination of USF steering committee meeting notes, trip reports, progress reports to WVDNR, NOAA, WVDEP, and EBTJV, survey responses, and personal observation. Agreement upon and development of a restoration plan for USF to address limiting factors occurred within the context of the before project network. Funding for the USF restoration effort was largely secured in the before project timeframe; however, some additional funds were raised during the construction/implementation phase to address some unforeseen challenges. In all time periods, the USF network demonstrated adaptive capacity. Effective implementation of restoration measures were completed in the during project timeframe. Social learning occurred throughout all restoration effort timeframes, but survey responses seem to suggest that the greatest strides in learning occurred before the project when all the actors had to understand the transdisciplinary nature of such a complex restoration effort. Technological innovation materialized during the construction/implementation phase as well as bio-physical monitoring after the project. Lastly, the structure and character of a potential future collaboration network, in addition to survey responses (81\% reported that they are extremely likely to encourage and/or participate in further stream restoration, and $79 \%$ reported that the USF effort fueled momentum in WV stream restoration), suggest network resiliency and momentum. 


\subsection{Research Question \#3: Impact of Removing Most Central Organizations}

Table 2 illustrates a ranking of the top five most central organizations over the USF network evolution with WVDNR, WVU, and CVI holding the top three positions for all timeframes.

Table 7 presents dramatic changes to the USF before project network with the hypothetical removal of the top three most central organizations WVDNR, WVU, and CVI. The size of the network drops substantially from 55 actors to 28 . Cross-boundary exchange plummets from $27.1 \%$ to $16.0 \%$, and the network becomes much less centralized dropping from $40.3 \%$ to $19.1 \%$. The before project network density without the most central organizations remains nearly the same; however, diameter increases resulting in two additional steps necessary to reach all actors while network betweenness centrality would decrease from $37.5 \%$ to $23.3 \%$. In all other time frames, the USF network was comprised of just one component, but with the removal of WVDNR, WVU, and CVI, it becomes more fragmented into three distinct network components.

\subsection{Research Question \#4: Potential Future Restoration Network}

Table 5 describes a potential future restoration network with 58 individuals representing 28 organizations of 8 different types. This network has a cross-boundary exchange of $38.4 \%$ which is higher than before project or during project levels, and a network degree centralization and density of $39.9 \%$ and $8.8 \%$, respectively. The future network diameter is the smallest of any timeframe; however, its network betweenness centrality is the highest at $39.7 \%$. Table 3 explains that a future network would largely busy itself with planning and education/outreach endeavors. WVDNR is the most central organization in the future network along with CVI in the second position and WVU in the third. 


\subsection{Discussion}

Before a discussion and interpretation of results, it may be helpful to review the hypothetical extremes in SNA. Figure 2 represents a hypothetical star topology of a 100-actor network. This star network represents perfect $(100 \%)$ centralization whereby one actor is connected to all other actors in the network, and all other actors have no connections to one another. While this is an extremely powerful position for the central actor allowing him or her to be highly effective in coordination and problem solving, network closure and density are $0 \%$ representing a very vulnerable, and perhaps unsustainable, overall network. Should the central actor be removed, the entire network disappears. Conversely, Figure 24 is a hypothetical clique topology of a 100-actor network. This clique network represents perfect network closure and density (both 100\%) whereby every actor is connected with all other actors. This network has $0 \%$ centralization, which means everyone has equal access to resources and information exchanges. While this perfect clique structure may promote resiliency and collective action, it is highly vulnerable to homogenization of knowledge and is lacking in problem solving capacity (Table 1) (Fliervoet, et al., 2016).

The aim of this study was to more deeply understand the effectiveness of the USF adaptive natural resource governance system by providing empirical evidence that relates social network structure and dynamics to stream and watershed restoration outcomes in hopes to inform and encourage more social-ecological systems restoration in WV and beyond. SNA was used to analyze USF network dynamics and results demonstrate that USF network structure and character varied over before, during, and after time periods. Moreover, these network dynamic analyses yielded different results than merely studying an overall time independent (static) composition of USF network data, which supports the assertion that more empirical studies of network dynamics are needed (Angst, \& Hirschi, 2016; Bodin, \& Crona, 2009; Stein, et al., 2011). While direct 
cause/effect relationships between network structural dynamics and restoration effort outcomes cannot be drawn, results here strongly support theoretic and empirical evidence that natural or common pool resource network structure and character, as illustrated in the case of USF stream restoration, change over time and can be linked to performance (Angst, \& Hirschi, 2016; Bodin, \& Crona, 2009; Stein, et al., 2011).

An unexpected result was the size and diversity of the USF before project network. While 95 stakeholders were asked to complete the survey, meeting notes and records suggested that only a small percentage of those actors were actively engaged in restoration effort initiation. Moreover, network degree centrality and density signifies that this original group of stakeholders were tightly connected and well organized for coordination and collective action. While WVDNR, WVU, and CVI were the most central organizations before the project (and remained so through all time periods), the diversity of the initial network included 19 different organizations representing academia, federal government, volunteers, NGOs, the private sector, and state government. Hence, this confirms that the USF was not only an adaptive governance system, but can also be characterized as a polycentric governance that emerged and evolved to complete a complex socialecological system restoration endeavor.

The effectiveness of the USF adaptive and polycentric governance can be explained, in part, by analyzing the network structure and character dynamics in relation to restoration effort outcomes. The before project network was moderately centralized in both degree (40.3\%) and betweenness (37.5\%) as compared to other natural resource networks found in the literature (Stein, et al.; Sandström, \& Rova, 2010; Fliervoet et al., 2015). The before project network density was the highest of all time periods. From Table 1, this network structure and character indicates effectiveness in problem solving, coordination, and collective action along with trust in exchanges. 
Furthermore, the relatively high betweenness centrality for this before restoration network as compared to other time periods, may have offset some potential drawbacks of more closed networks (e.g. homogenization of ideas, stifling of creativity) by facilitating the brokering of novel information. This, at least in part, explains the before project network outcomes in developing restoration plans and strategies as well as raising the majority of project funding (Table 6).

During the project, more outcomes are revealed as the effective adaptive governance supported technological innovation and completing restoration construction/implementation on schedule and within budget (Table 6). In this phase, the network size nearly doubled and diversity increased dramatically. This during project network became less dense and centralized which contradicts Angst and Hirschi's (2016) results, pertaining to nature resource governance maturation, but supports the theory that top-down centralized management is less effective for common pool resources (Bodin, \& Crona, 2009). These decreases in network centralization and density when combined with an increase in cross-boundary exchange help explain the heterogeneity of ideas and innovation that was essential to complete this most intensive phase of the project.

After the project, the network decreased in size and diversity, but maintained levels above the network before restoration. This along with a large increase in cross-boundary exchange suggests a measure of network resiliency as stakeholders continued to communicate, collaborate, and learn from one another. Network density dropped substantially during this phase as stakeholders turned their attention to new projects and obligations. However, the core group of most central actors (WVDNR-WVU-CVI triad) maintained ties across the network and capitalized on project momentum by producing a PBS documentary "Stewards of Shavers Fork" (Appendix 8.2) detailing the UFS restoration effort. An increase in the after project network centrality to a level 
higher than any other time period may explain the core-group transformation of lessons learned from USF into a formal WV aquatic habitat restoration program plan (Appendix 8.1).

While the USF restoration effort represents an example of effective natural resource governance, its core-periphery like structure (i.e. WVDNR-WVU-CVI at the core in all time periods) begs the question of network vulnerability and sustainability. More precisely, would the USF restoration effort have happened without these central organizations? While a definitive no cannot be asserted, the hypothetical removal of the WVDNR-WVU-CVI triad from the before project network would have had significant repercussions (Figure 23). The network size and diversity would have plummeted along with cross-boundary exchange and network degree centralization indicating a much reduced capacity for problem solving and innovation (Table 7). This may have greatly hampered restoration plan development and fund raising without which there would have been no USF restoration effort. Without WVDNR-WVU-CVI, reachability and betweenness centrality would decline as well which would have limited network information exchange and access to resources. However, network density would have slightly increased indicating connectivity, trust, and a capacity for collective action among the remaining organizations, which may have led to different, yet positive, outcomes.

Survey respondents were also asked with whom they might collaborate/communicate with regarding future Shavers Fork and/or other stream restoration. SNA of this future network, in addition to survey responses to non-network questions (e.g. How likely are you to encourage, support, and/or participate in more stream/watershed restoration work in West Virginia?), strongly suggest a resilient and sustainable future stream restoration network. Cross-boundary exchange and network betweenness centrality scores for the future network support the notion that USF restoration participants are planning to continue working together and learning from one another 
(Table 5). Moreover, the results of the most central organization analyses show the WVDNRWVU-CVI triad as key contributors in facilitating this future network (Table 2).

While this study serves to inform future stream restoration efforts by illuminating linkages between social network dynamics and outcomes, it is not without limitations. First, direct cause/effect relationships between social network structure and performance are not realized. Social capital, along with other community capitals such as natural, financial, human, cultural, built and political, must be integrated for composite evaluation to fully understand direct cause/effect relationships in natural or common pool resource management (Emery, \& Flora, 2006). A second limitation to this study is the retrospective design. It is difficult for respondents to recall, with a high level of accuracy, the nature and dynamics of relationships over a long period of time. In this case, respondents were asked to record relationships over a 10-year period. Nevertheless, retrospective surveys are less costly and time consuming to administer and can be augmented with meeting records and other project documentation; however, a true longitude study where respondents are queried yearly or more frequently during a restoration effort would likely yield better results by minimizing recall error.

The third and fourth limitations are also in the realm of data collection. Possibly relating to the recall issue previously acknowledged $\mathrm{Li}$, it appears that some respondents may tend to overstate their participation or perhaps "importance" when queried about previous relationships especially in light of positive outcomes and success. For instance, a few respondents indicated they had a high level of communication/collaboration with other stakeholders regarding the USF restoration before the project began. However, this participation could not be corroborated by project documentation (i.e., meeting records, reports, and personal observation). The fourth and last limitation to be discussed deals with the difference between frequency of 
communication/collaboration and the importance/relevance of such. Respondents were asked how frequently they communicated/collaborated with others before, during, and after the USF restoration effort including the primary subject matter (planning, funding, construction, biophysical monitoring, and education/outreach). By virtue of the study design, frequency becomes a surrogate for importance/relevance when, in fact, less frequent communication/collaboration may be just as, or even more, critical to achieving the overall network goals should the value of that information/resource exchange be comparatively high. This can partially be addressed by valuing the strength of ties, but more so by valuing the information/resources being exchanged.

Despite limitations, this study contributes empirical results to what has been deemed to be lacking in the natural resource governance literature: (1) network structural dynamics of natural of common pool resource management and (2) evaluation of social networks in stream restoration (Angst, \& Hirschi, 2016; Bodin, \& Crona, 2009). Anticipated future research includes exploring relationships between key actor attributes (e.g., professional background, age, affiliations) and dynamics in their roles or positions in the network over time. Furthermore, the exploration of stakeholder homophily and heterophily in terms of attributes, opinions, and roles may provide further insights into network performance. Lastly, Geographic Information Systems integration with SNA may also hold promise for evaluating spatially explicit actor attributes such as proximity to the project in relation to level of effort or network centrality (Figure 21). 


\subsection{Conclusions}

"You can't always get what you want, but if you try sometimes

you just might find you get what you need."

- Mick Jagger, 1969

If USF restoration participants were queried about what they wanted to see happen as a result of their efforts, the answer would undoubtedly be something like "We want a thriving brook trout population back in the USF, now." Several years have passed since the restoration efforts were completed, and biolift is indeed happening, albeit slowly. Egan et al. (2011) submit that ecological restoration is an act of faith, hope, and love, but perhaps it is also an exercise in patience. So, while the USF stakeholders continue to wait for what they want, they might just find they got something they need and can share. That is, a strong, diverse, and effective adaptive natural resource governance system which emerged and evolved to meet the challenges of restoring an important and complex social-ecological system. Moreover, this social capital persists today; new relationships have matured into sustainable partnerships that readily exchange ideas and resources for the betterment of WV streams and watersheds.

This study suggests that along with faith, hope, love, and patience, persistence and adaptability are also key characteristics of effective and sustainable ecological restoration. While for the purposes of this research, the USF restoration effort was bounded in time from 2009 to the 2013, in reality, the effort continues today. Much like ecological systems themselves, the adaptive cycle continues as many USF stakeholders, particularly those in the core group, continue to monitor the stream and plan for more restoration work. Summertime stream temperature continues to be a limiting factor in the USF; hence, a massive riparian tree planting effort at Spruce, WV is scheduled for 
May 2017. Riparian shading at Spruce, WV (one of the most open areas in the USF) will help to moderate summertime temperatures that are often lethal to brook trout. Funding for this planting effort is being provided by WVDNR and the EBTJV. Moreover, the Lake at Snowshoe also contributes to increased stream temperatures. The feasibility of rectifying warm water discharges from Snowshoe Lake during critical summer months is currently being discussed. Additionally, the WVU Cooperative Fish and Wildlife Research Unit will complete a long-term fish population dynamics study in the USF in June 2017. At that time, WVDNR will have an opportunity to evaluate and potentially modify adaptive management strategies such as future fish stockings and/or harvest restriction regulations. Therefore, the USF network restoration momentum continues on a trajectory of incremental positive change that suggests an adaptive cycle with perhaps no end in sight.

Participation in the USF restoration effort as well as its positive outcomes have instilled confidence and fueled momentum for stream and watershed restoration beyond Shavers Fork. The USF restoration effort inspired a formal and statewide Aquatic Habitat Enhancement Restoration Program Plan (Appendix 8.1) that calls for strengthening and expanding the existing restoration network to restore habitats in 33 streams and 17 impoundments over the next decade. Moreover, WVU is currently planning a more formal program that will provide research, education, and service support to this statewide effort. New conferences, curricula, and opportunities for experiential learning as well as additional stream and watershed restoration research is envisioned. Technological innovations realized in the USF restoration effort, such as the use of airborne and terrestrial lidar as well as drone-based mapping in planning and monitoring, are increasingly being used throughout the state in other restoration efforts. The use of baffled culverts for fish passage 
in WV was pioneered in the USF and is now considered to be a viable and cost-effective alternative for aquatic passage restoration in high gradient streams throughout the state.

The USF effort has also helped to foster more rail-based tourism and an exciting new initiative, Highland Adventures of Mountains, Rivers, and Rail (Appendix 8.4), that will ultimately be a 90 mile rail loop originating in Elkins, WV, following the Shavers Fork to Spruce, WV, then off the mountain to Cass, WV, and finally returning to the Shavers Fork at Greenbrier Junction. Along with many other attractions throughout the loop, the USF restoration is featured, and a special "restoration" train trip occurred in June of 2016. Durbin Greenbrier Valley Railroad plans to continue marketing these "restoration" trips as they present an opportunity to enjoy the watershed with minimal ecological impacts. Additionally, momentum from the USF restoration effort lead existing partnerships to complete habitat enhancement and stream restoration on Mill Creek, WV in Kumbrabow State Forests (Appendix 8.5). Here WVDNR, WVU, WV State Parks, WV State Forestry, and a few volunteers completed over 50 wood and rock-based habitat structures for brook trout during the summers of 2014 through 2016. Lessons learned from USF restoration helped to guide Mill Creek restoration which culminated in over 1.5 miles of brook trout habitat enhancement and hiking trail development.

Throughout much of the $20^{\text {th }}$ century, the river engineering paradigm reigned and declared war on natural rivers and their watersheds calling for them to be harnessed largely for economic gain (Everade \& Powell, 2002). Much like the recent shift from this river engineering paradigm to more holistic and integrated stream restoration approaches, top-down and centralized natural resource government appears to moving to more decentralized and adaptive structures as in the case of the USF. SNA affords an opportunity to quantify and analyze these structures as well as relate them to performance. Studying the USF network evolution with SNA methodology provides 
an example road map for other restoration initiatives to follow. For instance, sustaining a core leadership group of multi-disciplinary organizations appears to be important throughout all stages of restoration effort. This, however, could also represent a vulnerability should one or more of these core organizations leave the effort, perhaps suggesting a need to densify the network with more redundancy in expertise and knowledge. Moreover, learning from the USF, future restoration efforts should strive for inclusiveness, high diversity, and less centralization during the most intense implementation phases. After restoration, maintaining a high level of cross-boundary exchange, or in other words, open lines of communication and collaboration between a diversity of organizations supports an adaptive cycle and opportunities for more restoration.

Beyond the scope of this research, SNA offers an opportunity to draw relationships between individual actor attributes and their network position. For example, Steve Brown, a biologist and wildlife planner with WVDNR, was the most central USF actor throughout all time periods. Given that centrality suggests power, influence, and leadership, what are some of Steve's attributes that might explain his network position? What is his professional background, does he recreate in the USF watershed, is he affiliated with a certain set of conservation organizations, or does he simply live near the USF? Using SNA, Steve's attributes can be correlated to his network position thereby offering guidance in seeking leadership for other restoration efforts. Conversely, with SNA, the least central actor in the USF network can be identified and questions as to why this is so can be answered.

This research also sets the stage for more macro-level inquiries into watershed and conservation group capacity throughout the Mid-Atlantic region. CVI and EPA produced a Highland Action Plan in the early $21^{\text {st }}$ century designating the central Appalachians as a special place in need of protection and green infrastructure restoration/development. Over time, this effort faded largely 
due to decreasing in funding. However, did the once robust watershed organization capacity also fade? SNA could afford researchers and administrators a tool for assessing current capacity in the central Appalachians for watershed protection, conservation, and restoration. Future funding for restoration could then be targeted to groups with the most effective adaptive governance systems and the highest capacity for positive and incremental change.

This USF restoration effort was successful in many regards and the fish, anglers, and tourists are returning. This study demonstrated that SNA methods can be used to more deeply understand and expose the social capital that was both a result of and reason for near term and positive outcomes. The USF network through its evolution provides an example or road map to be followed in the restoration of other impaired streams in $\mathrm{WV}$, and indeed this is currently happening. Anthropocentric changes to rivers, landscapes, and ecological systems are nearly always described in negative terms; however, this need not be so, as in the case of USF, and the many other ongoing restoration efforts that have been fueled by the momentum and influence of the USF experience.

SNA research in ecological restoration in general, and stream/watershed restoration in particular, remains to be fertile ground for dissecting adaptive natural governance system dynamics, effectiveness, and performance. Yet, more empirical evidence is needed to compare similar sized networks over time and throughout different geographies. As previously stated, individual actor network position should be correlated with actor attributes to better understand relationships between actor qualities and their power, influence, and leadership in a particular restoration or conservation effort. Moreover, these correlations should also be studied through time to discover how actor positional dynamics relate to attributes such as level of effort, professional background, and/or conservation organization affiliations. This research suggests network dynamic studies yield different, and arguably better, results than merely studying a single slice in time. What is 
still needed is empirical evidence from truly longitudinal studies where respondents are queried regularly throughout an effort as opposed to a retrospective study.

Moreover, given the challenges in respondent recall stemming from the retrospective design, network data in the study were symmetrized. Future research should also evaluate directed network data where unreciprocated ties are explicitly recorded and analyzed. The directed network data should also be examined over time to gain deeper insights into actor or organizational influence and power, or a lack thereof. Finally, this research only analyzed the most central group of organizations, the WVDNR-WVU-CVI triad, and explored the impact of removing these from the before restoration network. Using SNA methods, other subgroups should be identified through clustering and subgroup analyses to further evaluate network strengths and weaknesses that ultimately relate to adaptive natural resource governance system effectiveness. 


\section{List of Figures}

Figure 1. Salvelinus Fontinalis (Brook Trout)

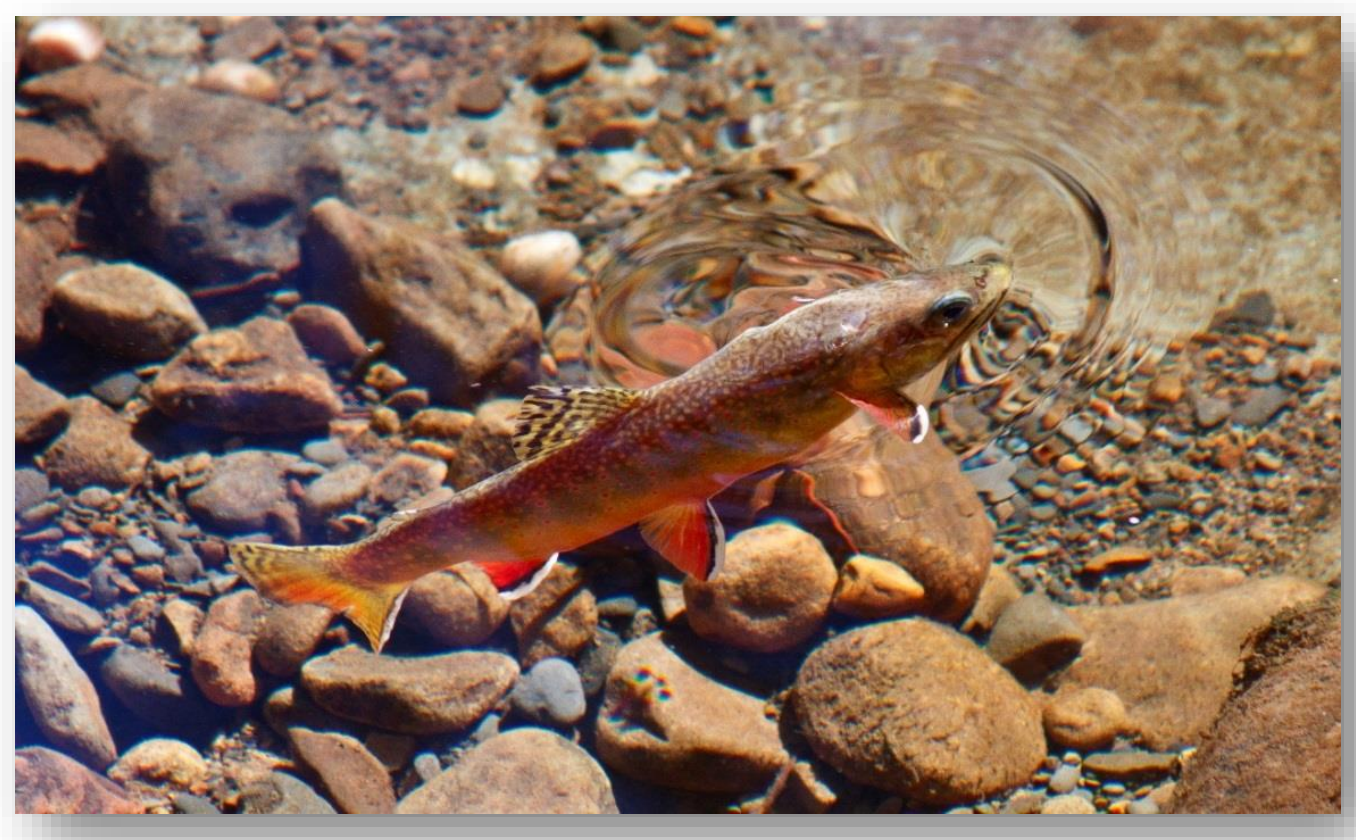

Source: Steve Brown, West Virginia Division of Natural Resources 
Figure 2. Hypothetical Star Topology - 100\% Network Degree Centralization

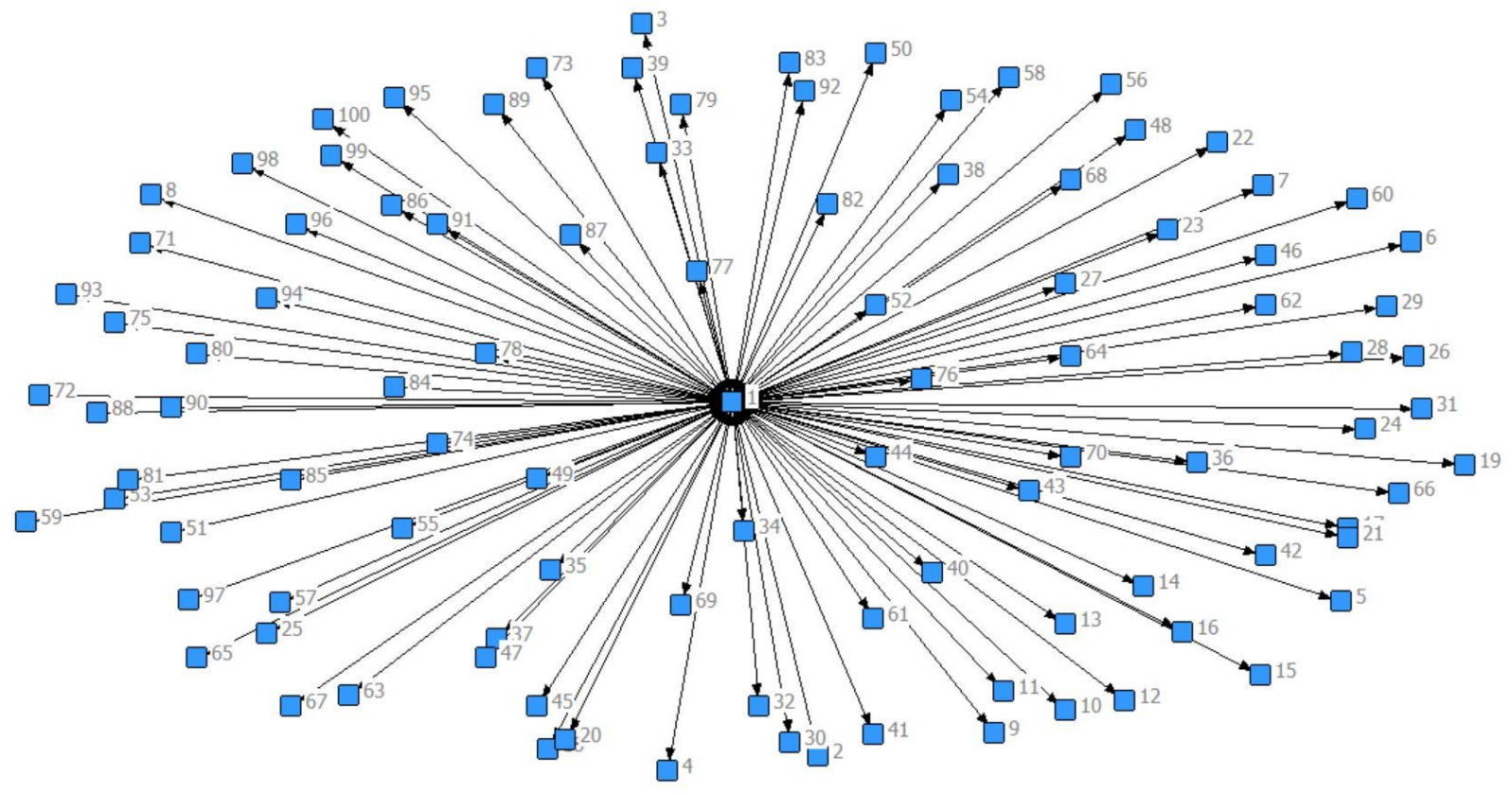

Figure 3. Articles with "Social Network" in title indexed in Google Scholar

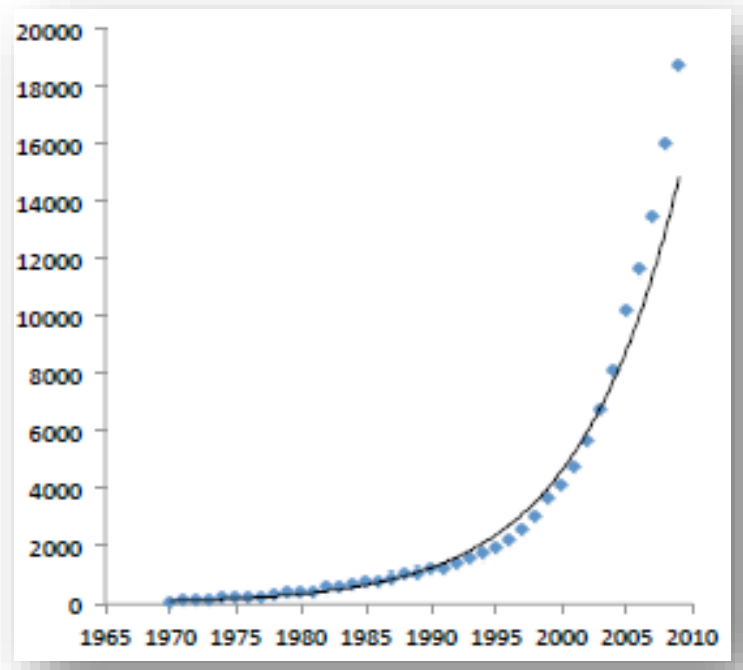

Source: Borgatti, S.P., \& Halgin, D.S. (2011). On network theory. Organizational Science. Articles in Advance, 1-14. 
Figure 4: Idealized Examples of Social Network Structures

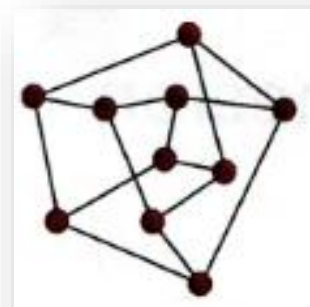

Diffuse Structure
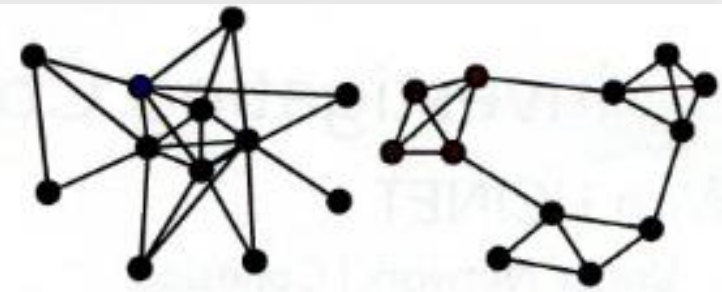

Core-Periphery Clique Structure Structure

Source: Halgin, D.S., \& Brass, D. (2016). Centrality Lecture. University of Kentucky Links Workshop. 18.

Figure 5. Hypothetical Company Organizational Chart vs. Communication Network Visualization (sociogram)

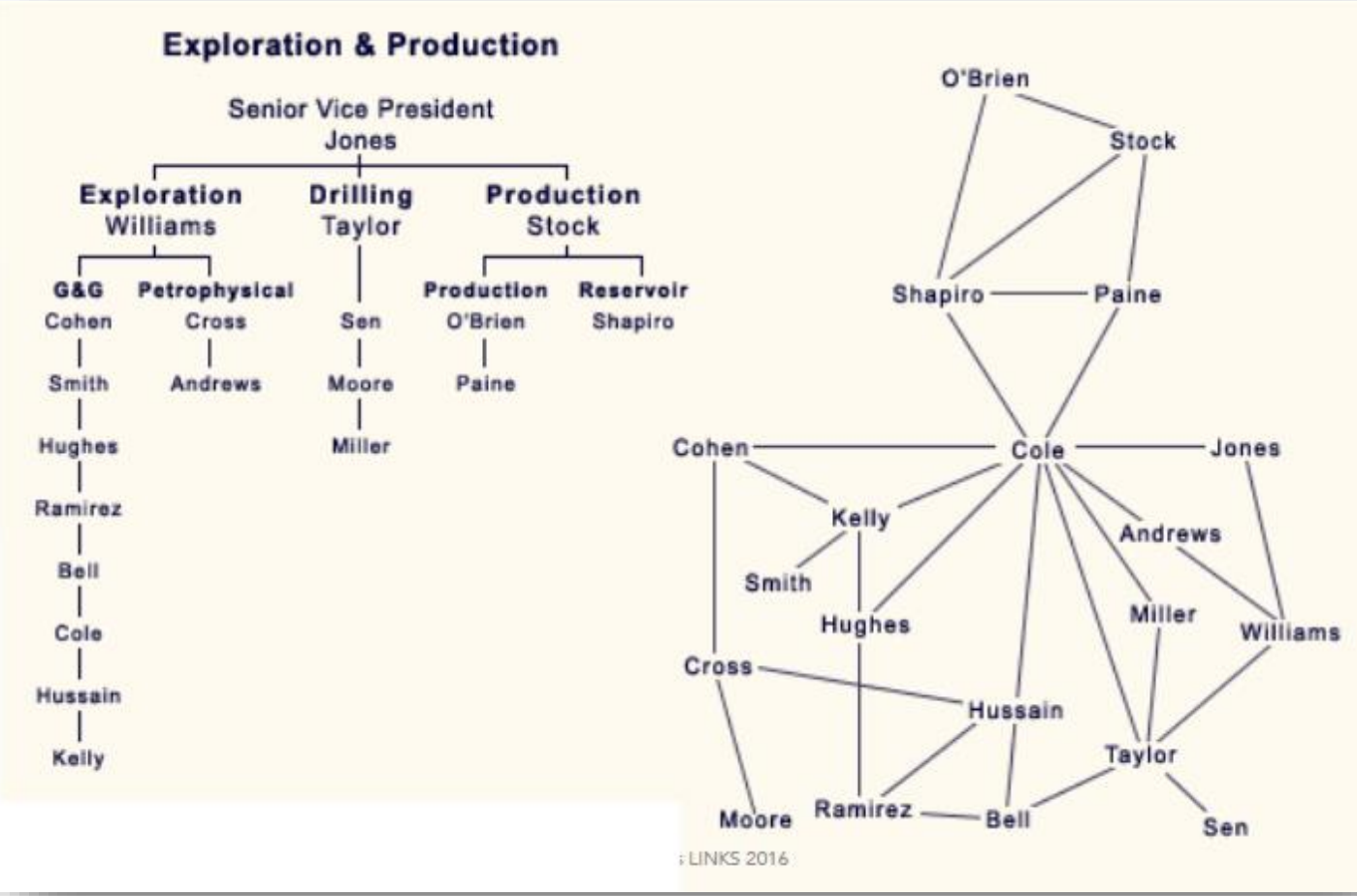

Source: Cross, R., Parker, A., Prusak, L., \& Borgatti, S.P. (2001). Knowing what we know:

supporting knowledge creation and sharing social networks. Organizational Dynamics 30(2): 100-120. 
Figure 6. Map of Upper Shaver Fork Watershed

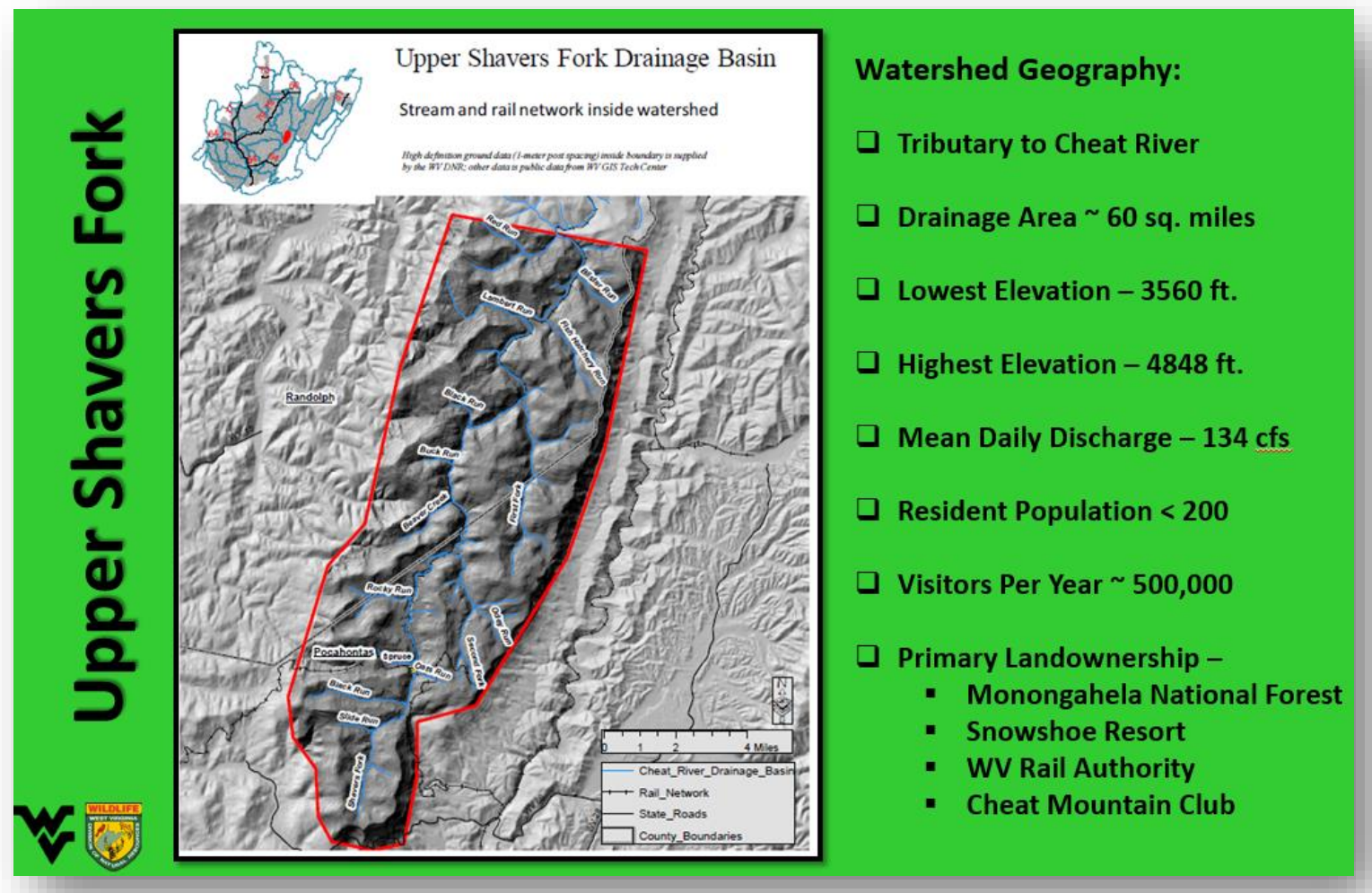

Figure 7. Historic Photo of Fishermen at Cheat Mountain Club

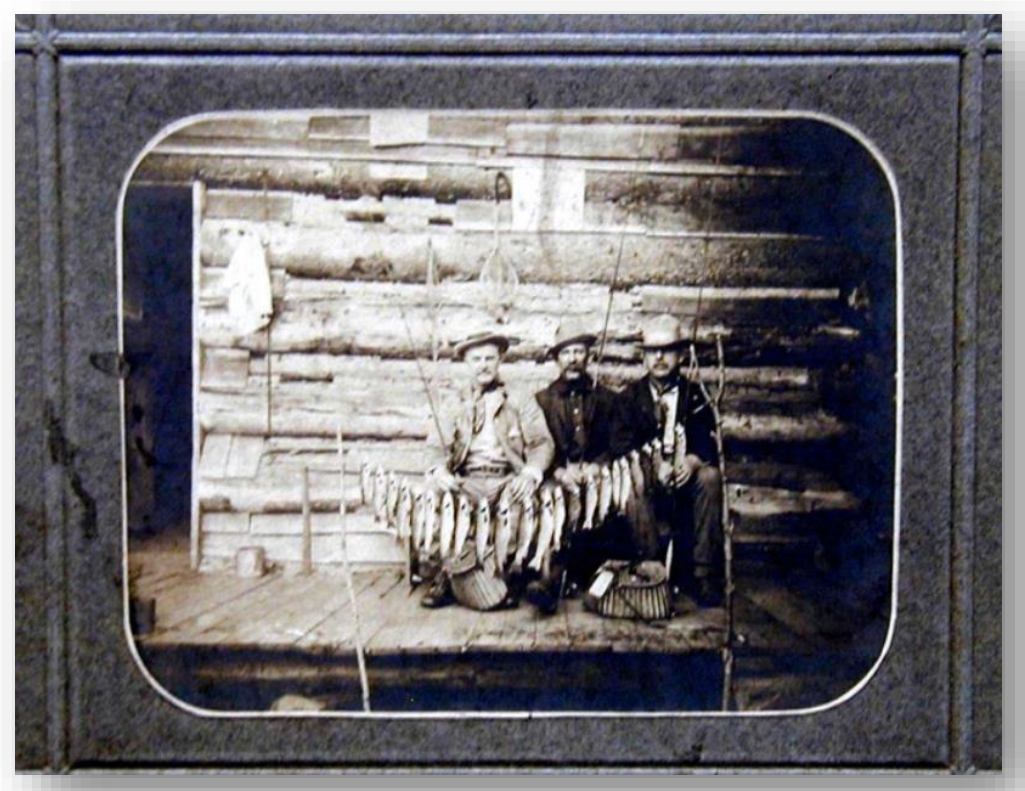

Source: Unknown 
Figure 8. Stakeholders and Partners at Spruce

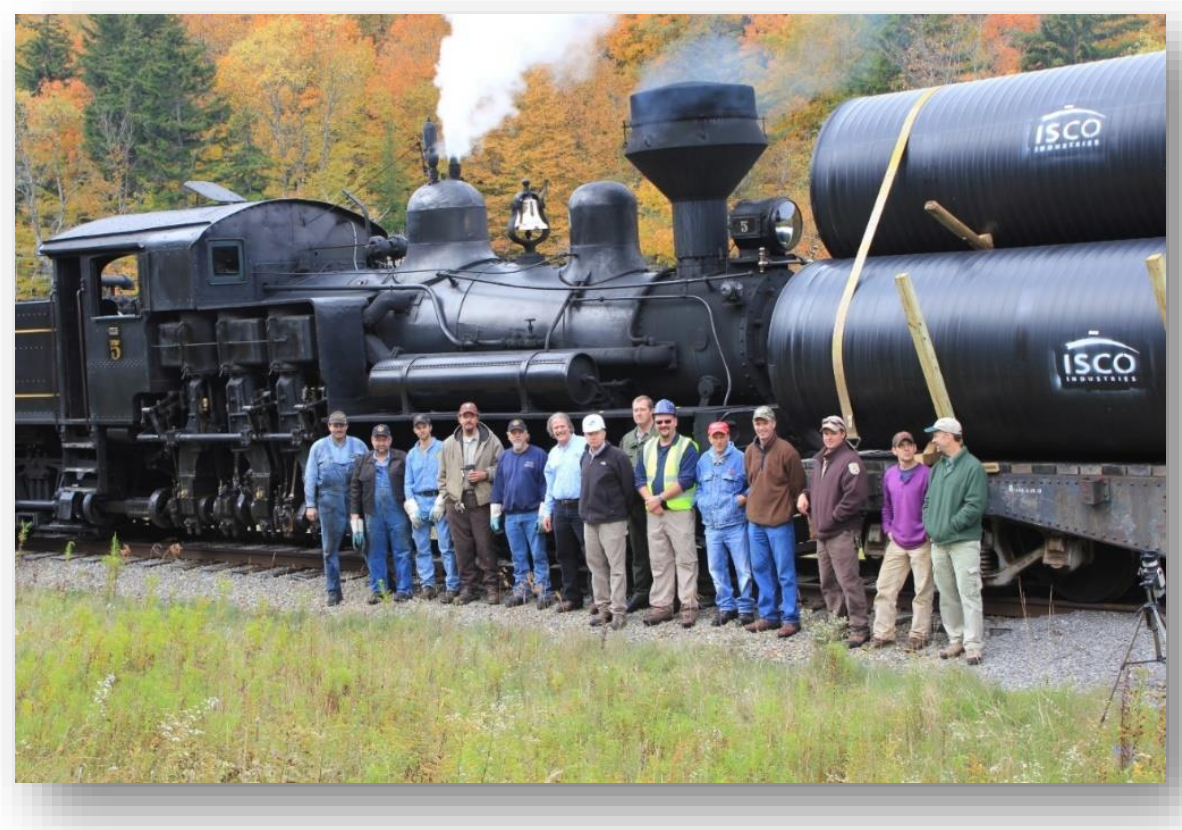

Figure 9. Beaver Creek

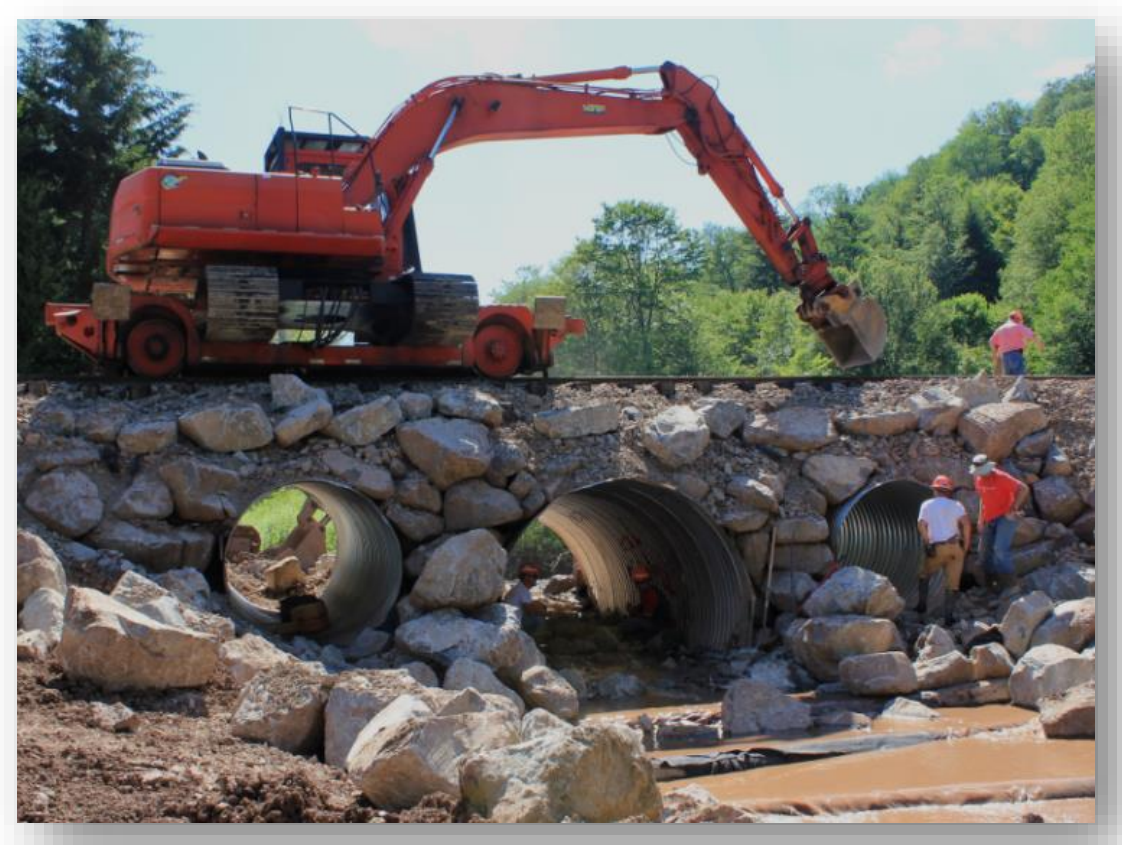


Figure 10. Lamothe Run

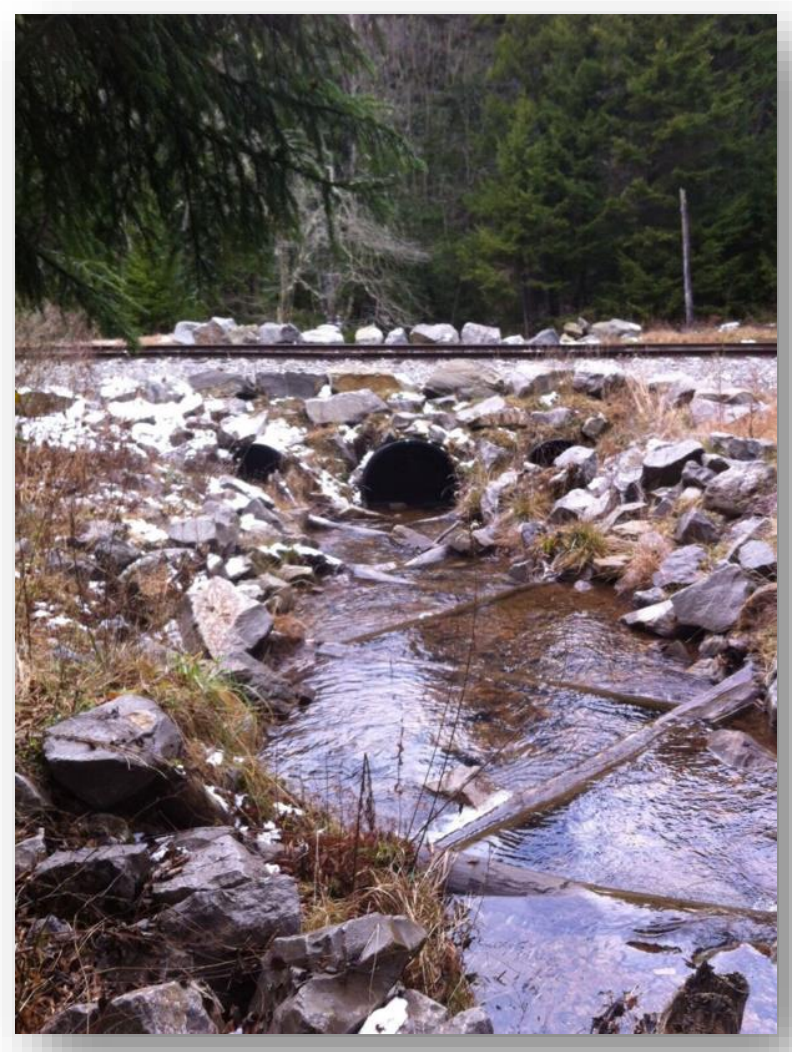

Figure 11. Oats Run

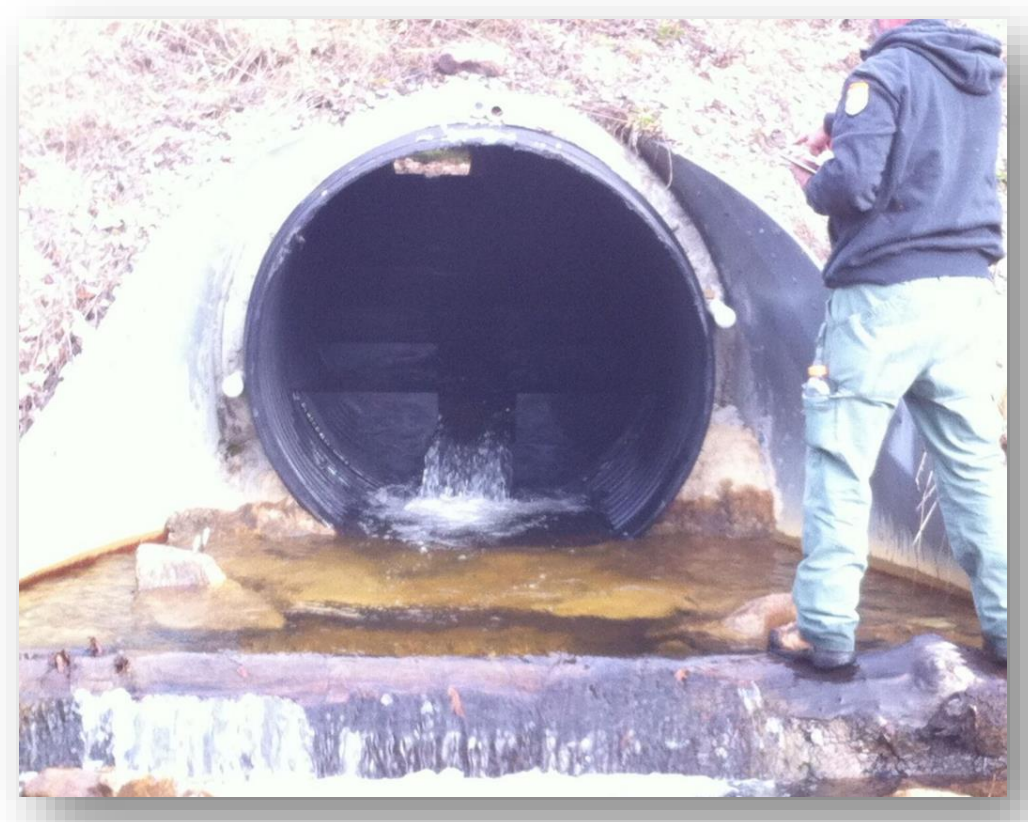


Figure 12. Example Mainstem Restoration Instream Structure (j-hook)

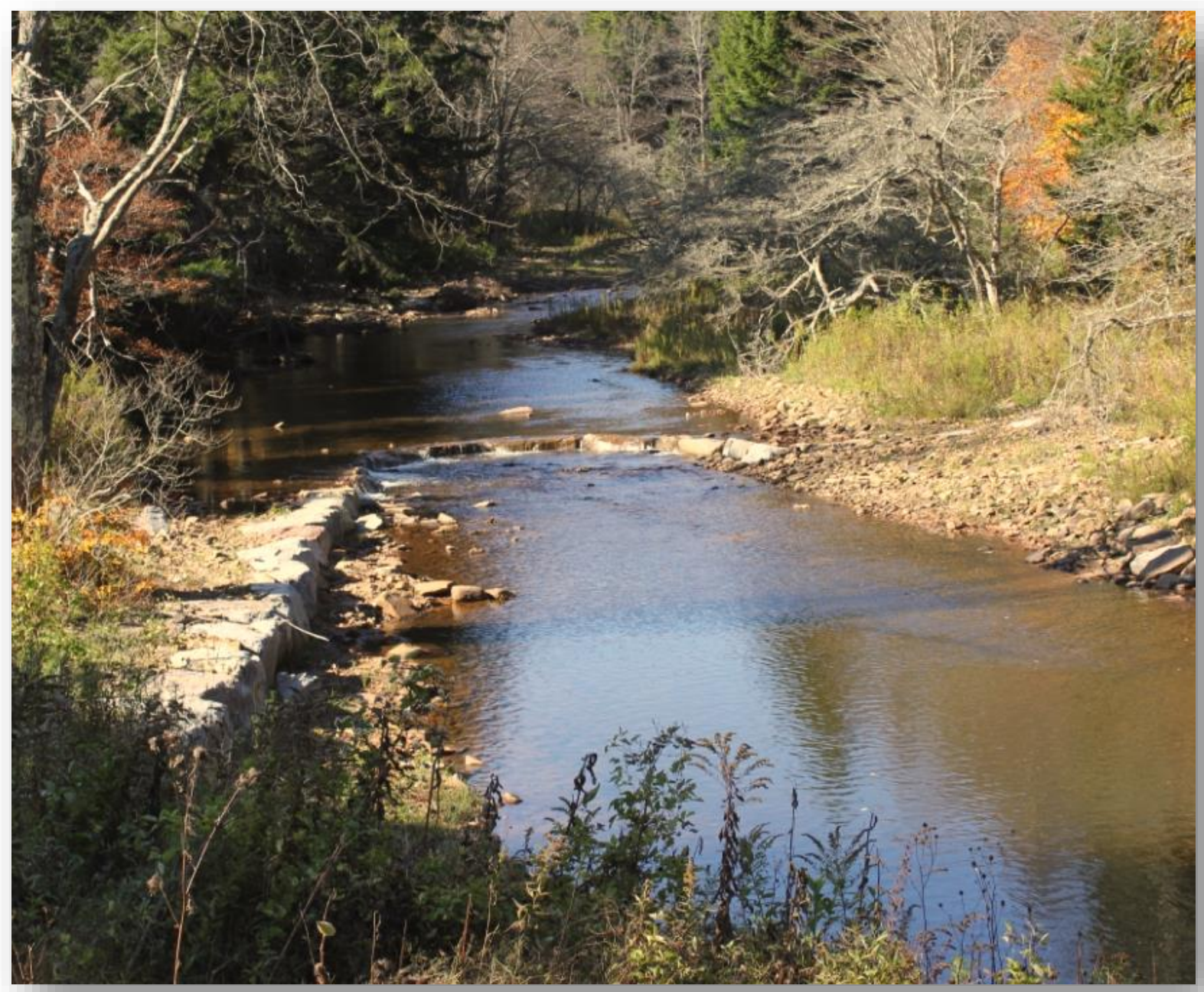


Figure 13. USF Network Respondent Diversity: Professional Background

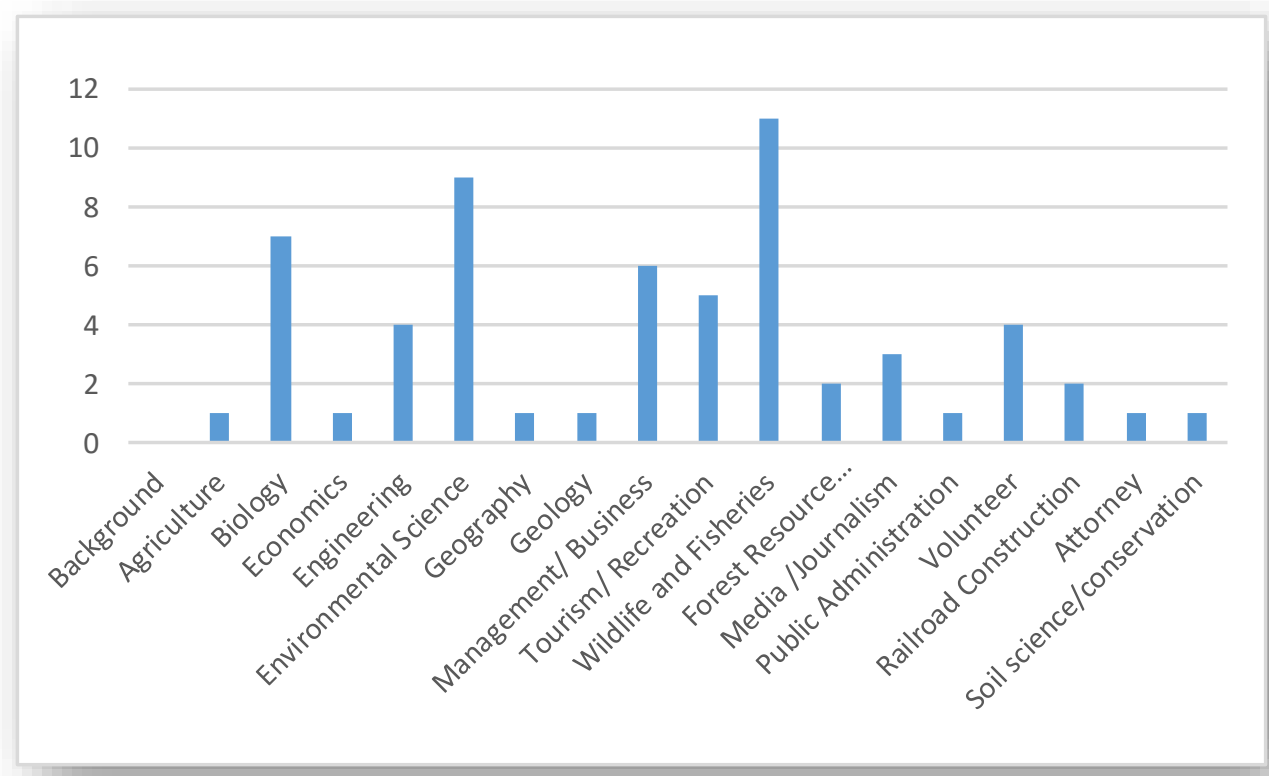

Figure 14. USF Network Respondent Diversity: Education

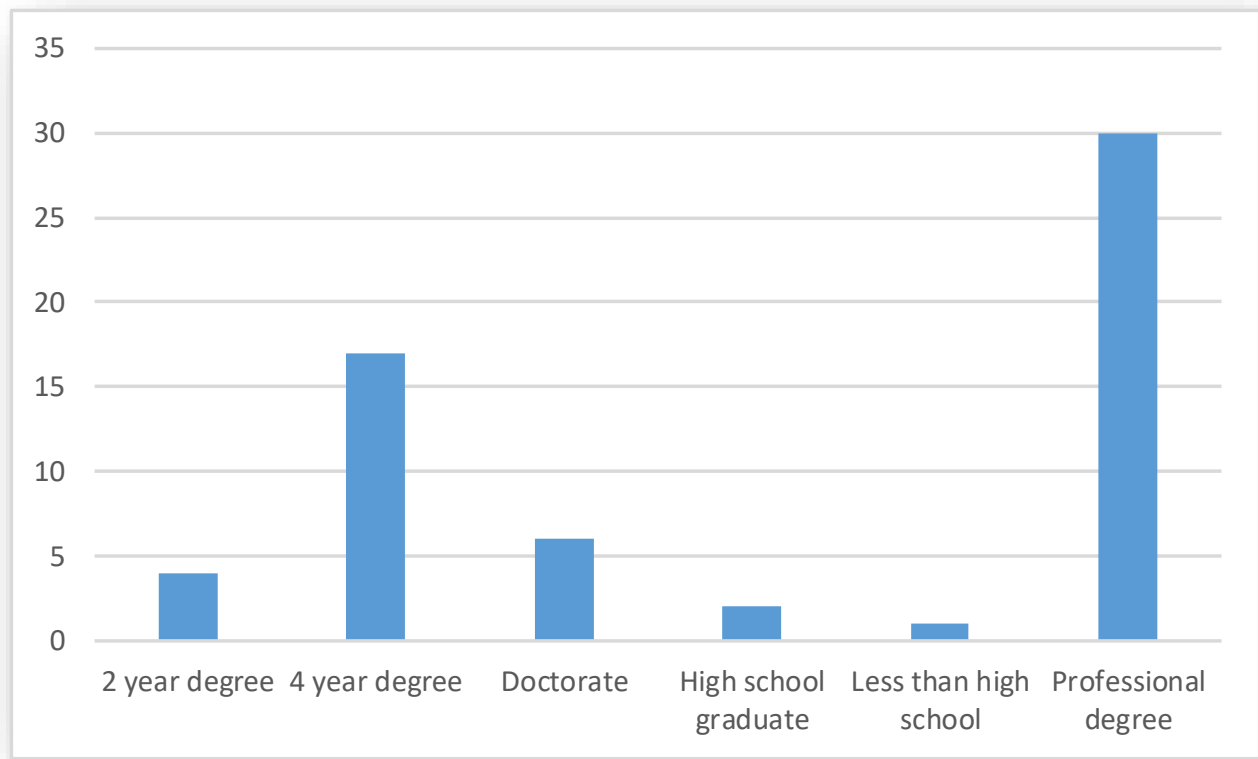


Figure 15. USF Network Respondent Diversity: Age

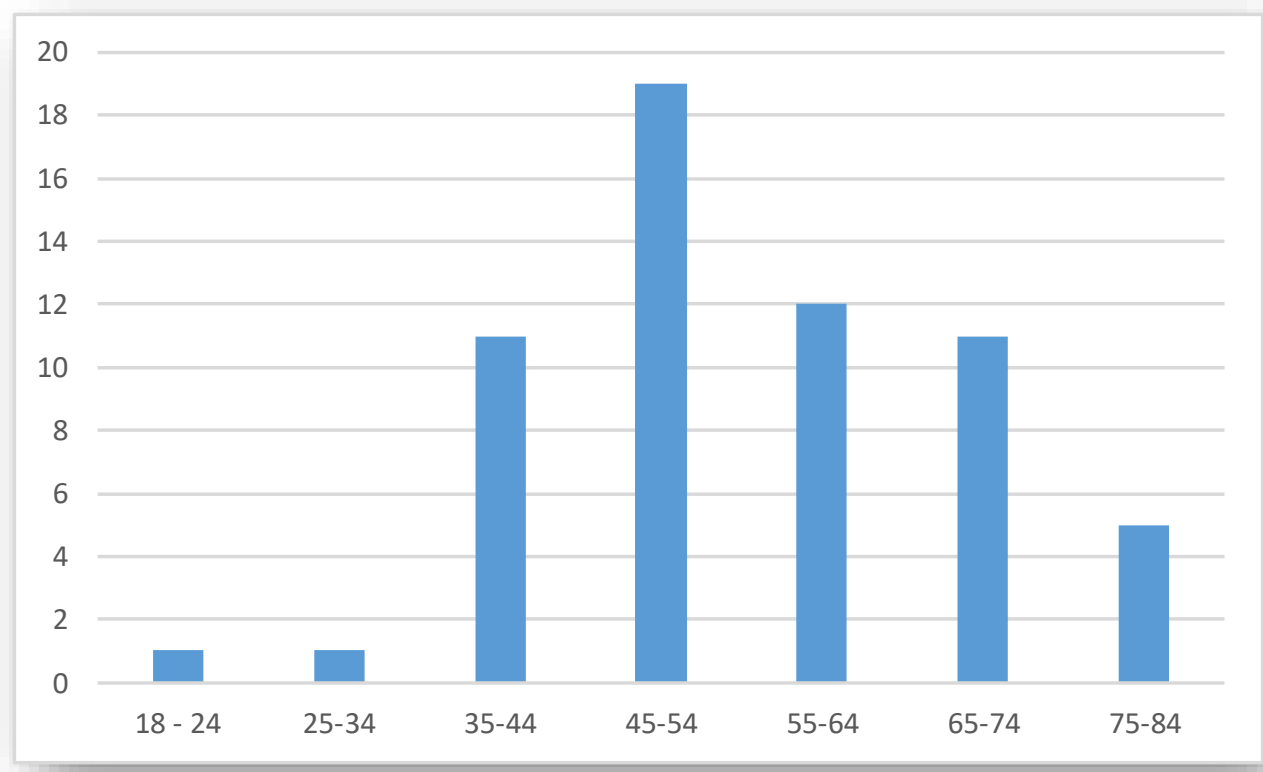

Figure 16. USF Network Respondent Diversity: Other Conservation Organization Affiliation

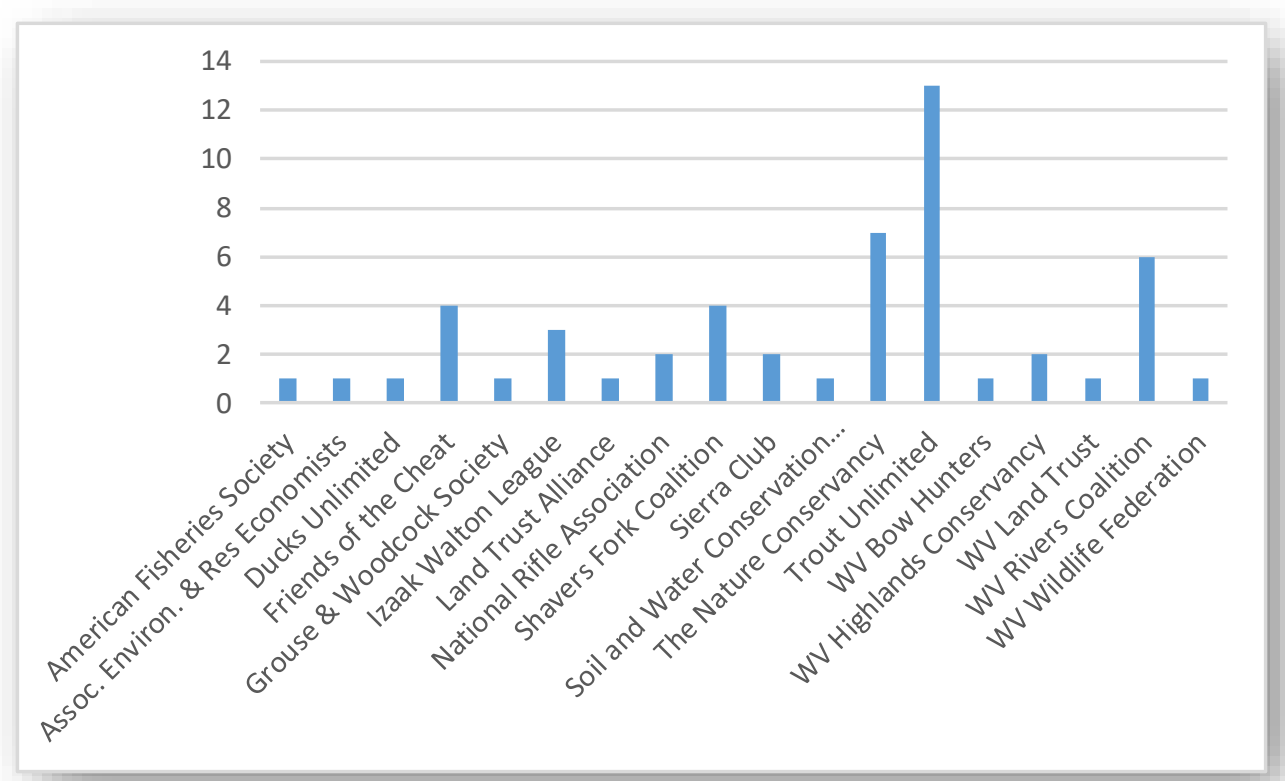


Figure 17. Map USF Network Respondent Residence in Proximity to Project Area: (a) Within West Virginia, and (b) Outside West Virginia.
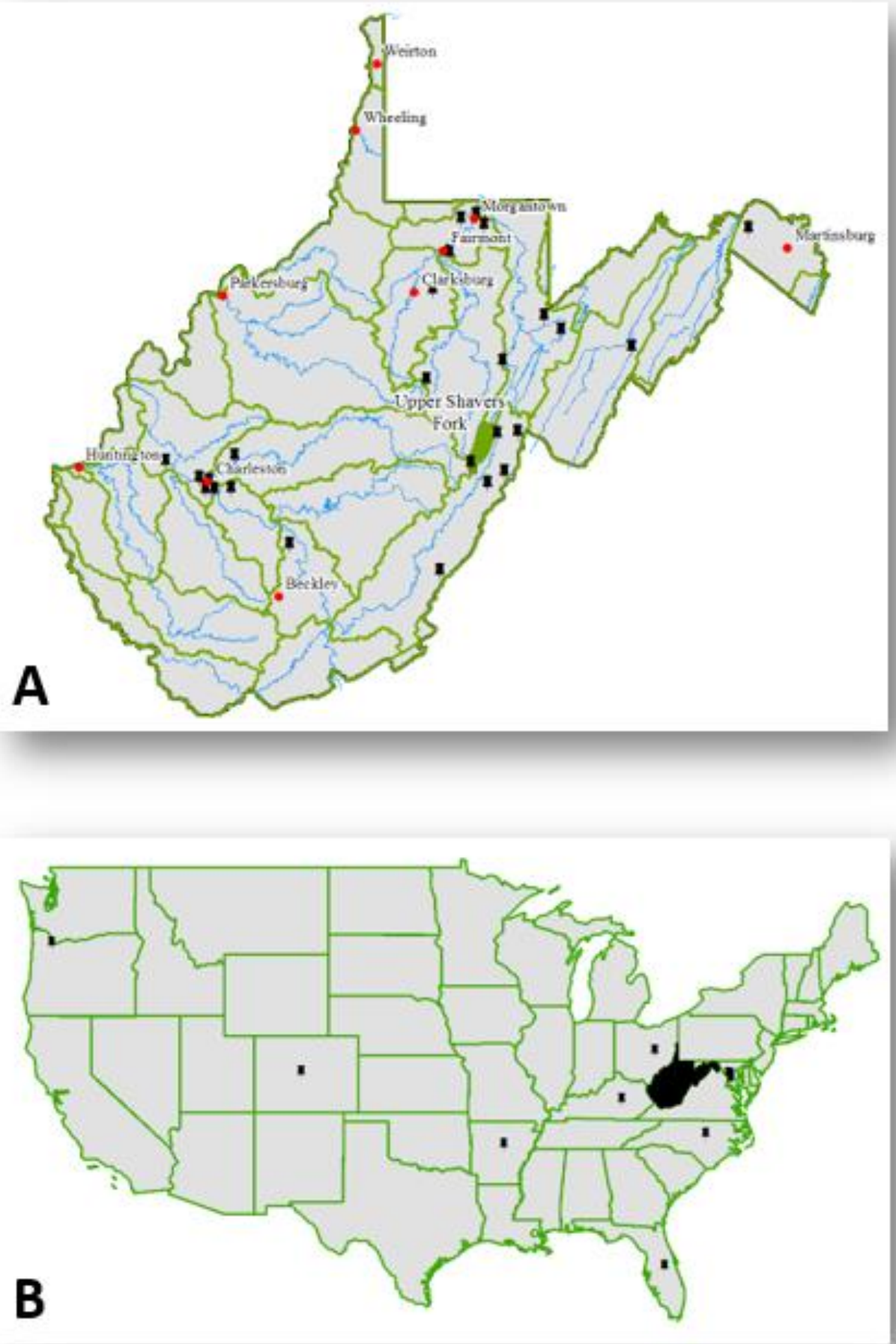
Figure 18. Map of (a) USF Overall and Time Independent Network by Individual Actor and (b) USF Overall and Time Independent Network by Organization.
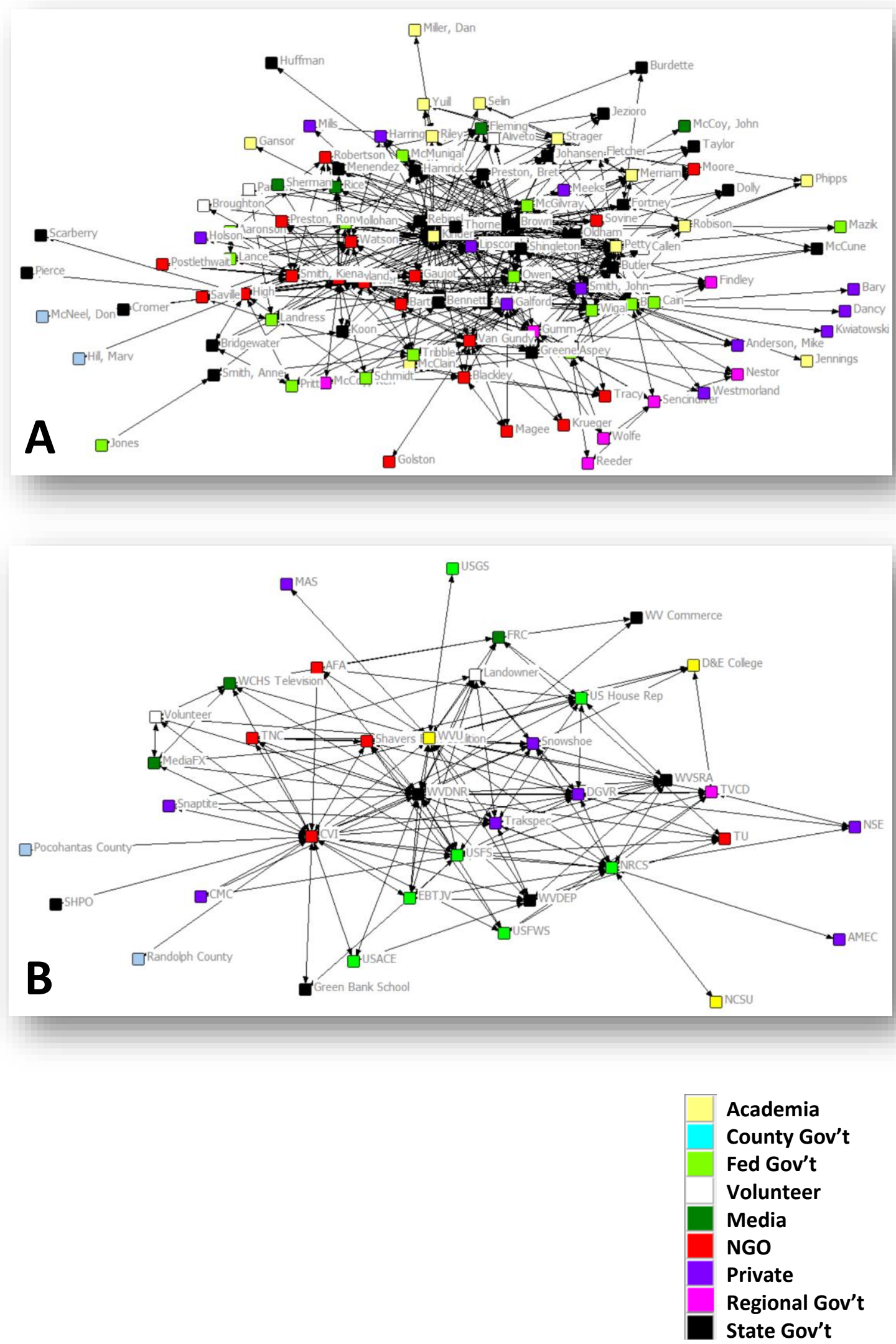
Figure 19. Map of (a) USF Network by Individual Actor Before Restoration (2009) and (b) USF Network by Organization Before Restoration (2009).
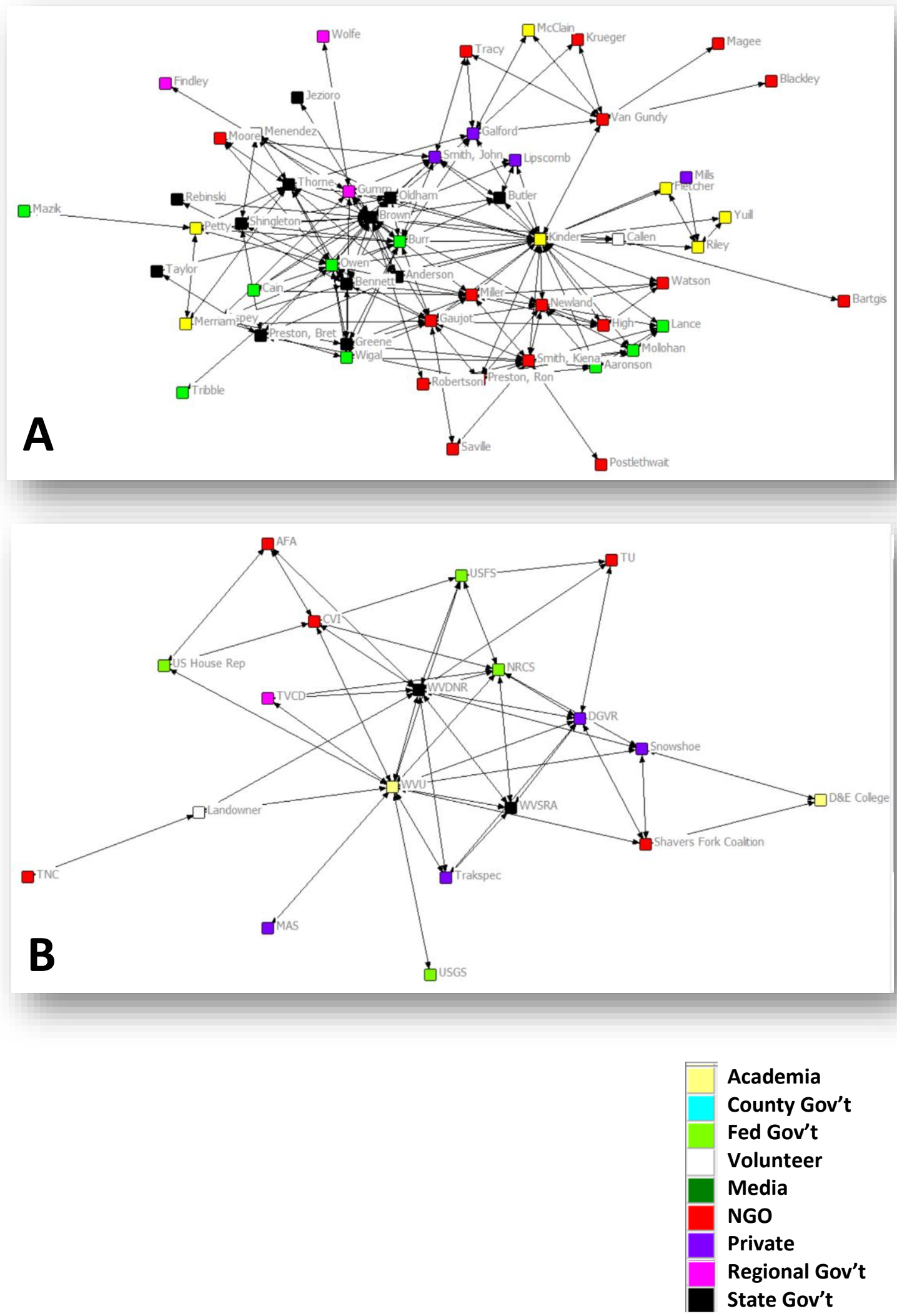
Figure 20. Map of (a) USF Network by Individual Actor During Restoration (2009-2013) and (b) USF Network by Organization During Restoration (2009-2013).
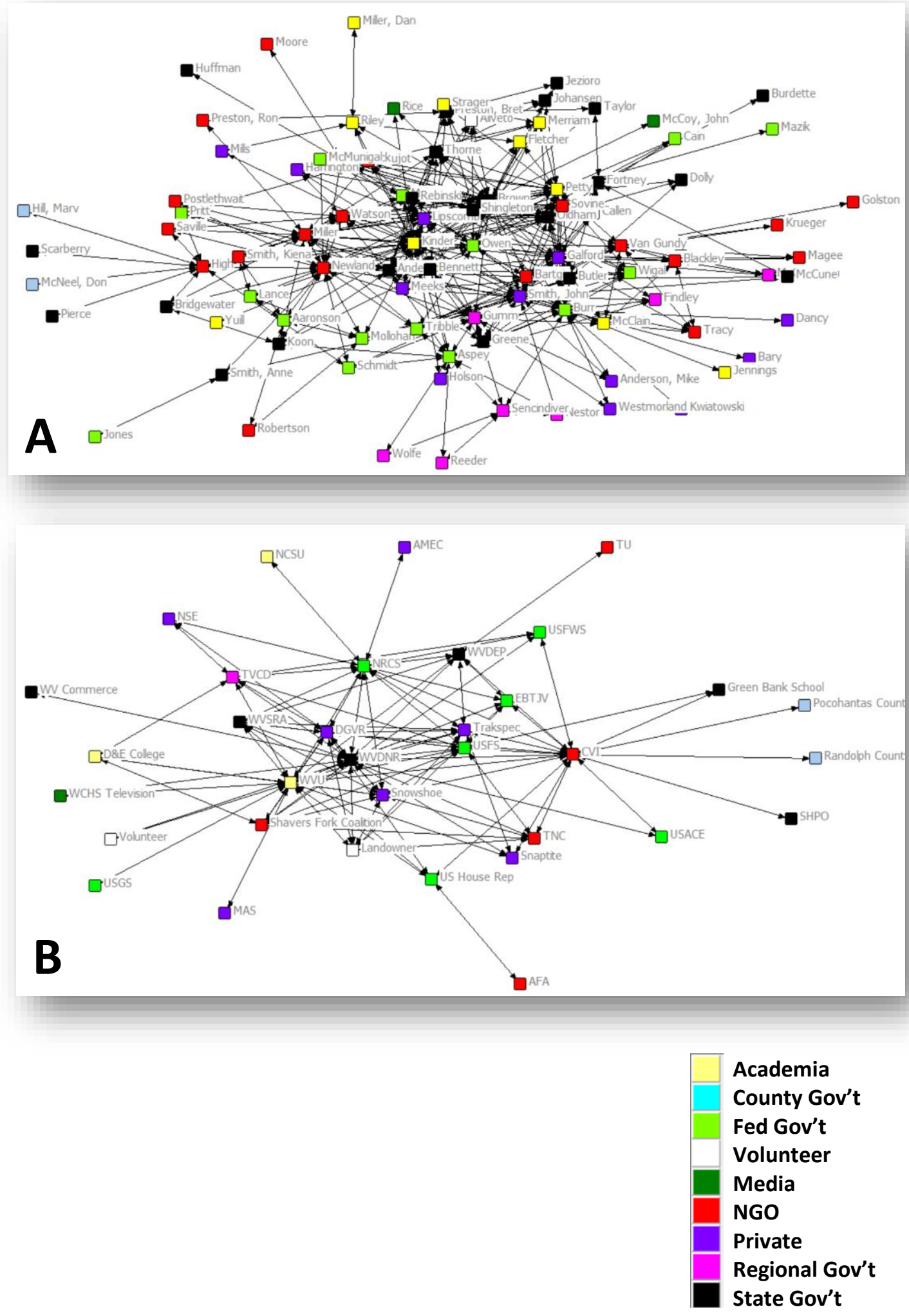
Figure 21. Map of (a) USF Network by Individual Actor After Restoration (2013-now) and (b) USF Network by Organization After Restoration (2013-now).
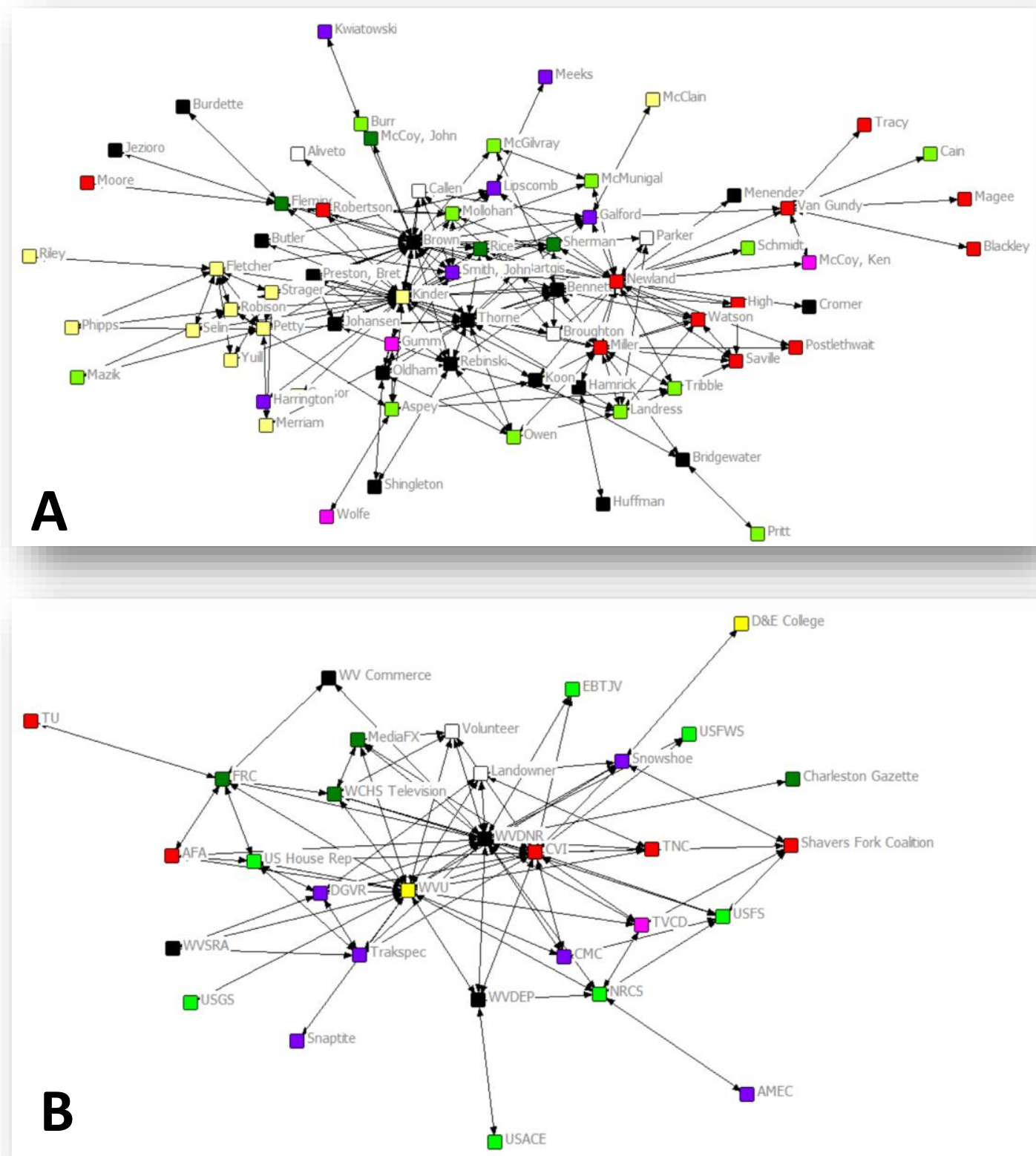

Academia
County Gov't
Fed Gov't
Volunteer
Media
NGO
Private
Regional Gov't
State Gov't


Figure 22. Map of (a) USF Network by Individual Actor Potential Future Collaboration (2017 and beyond) and (b) USF Network by Organization After Restoration (2017 and beyond).
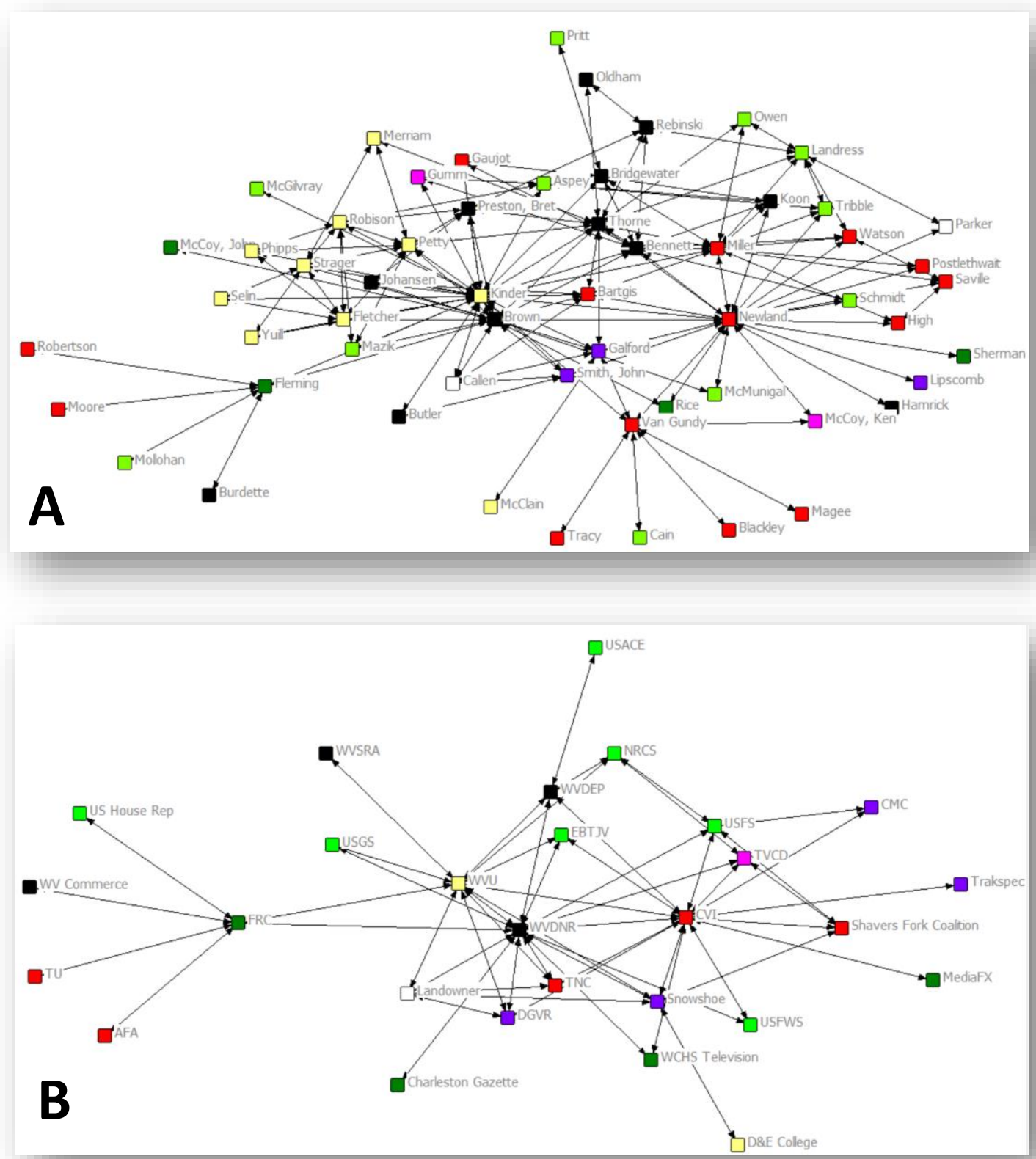

Academia

County Gov't

Fed Gov't

Volunteer

Media

NGO

Private

Regional Gov't

State Gov't 
Figure 23. Map of (a) USF Network Before Project with Most Central Actors Removed and (b) USF Network Before Project with Most Central Organizations Removed.
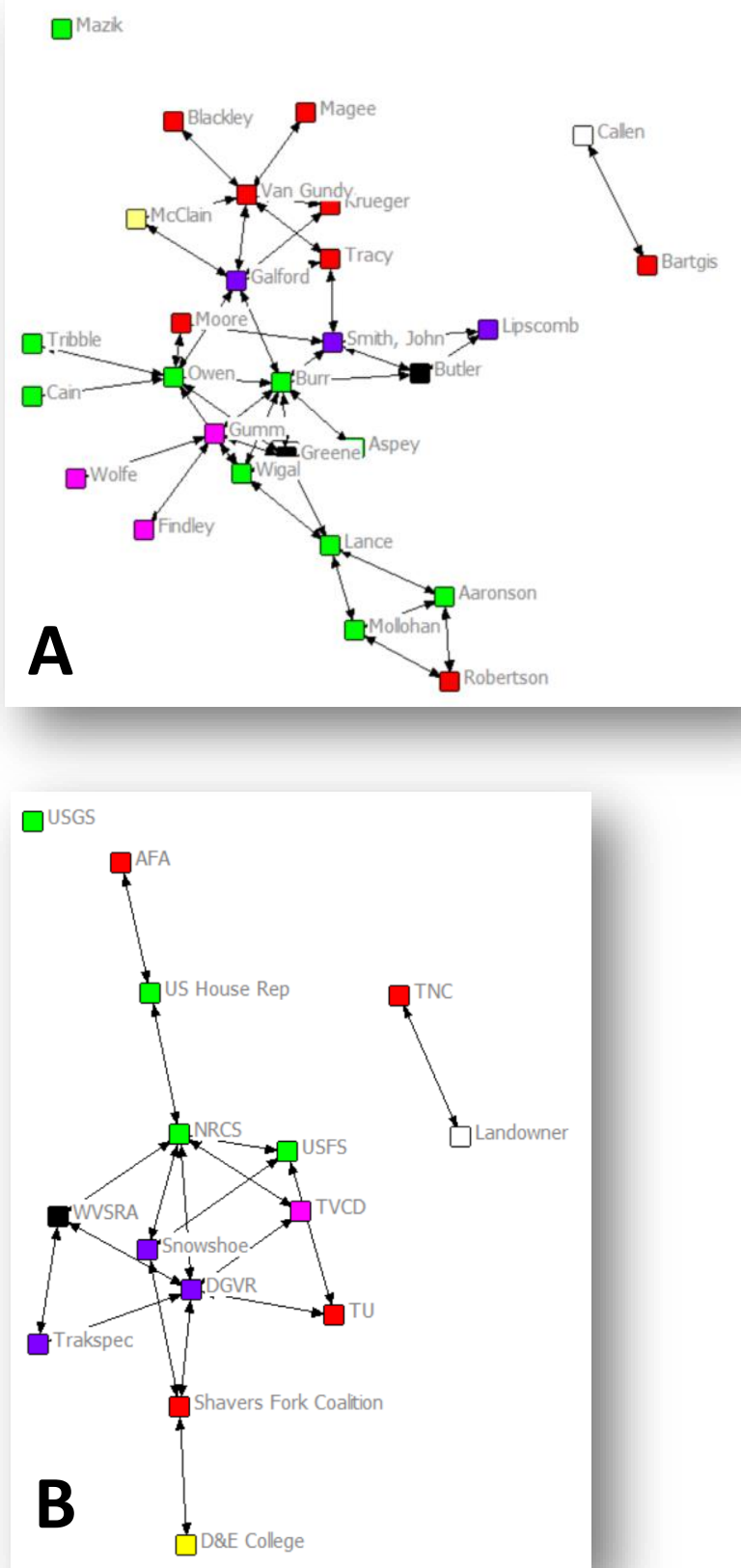
Figure 24. Hypothetical Clique Topology - 100\% Density and Closure

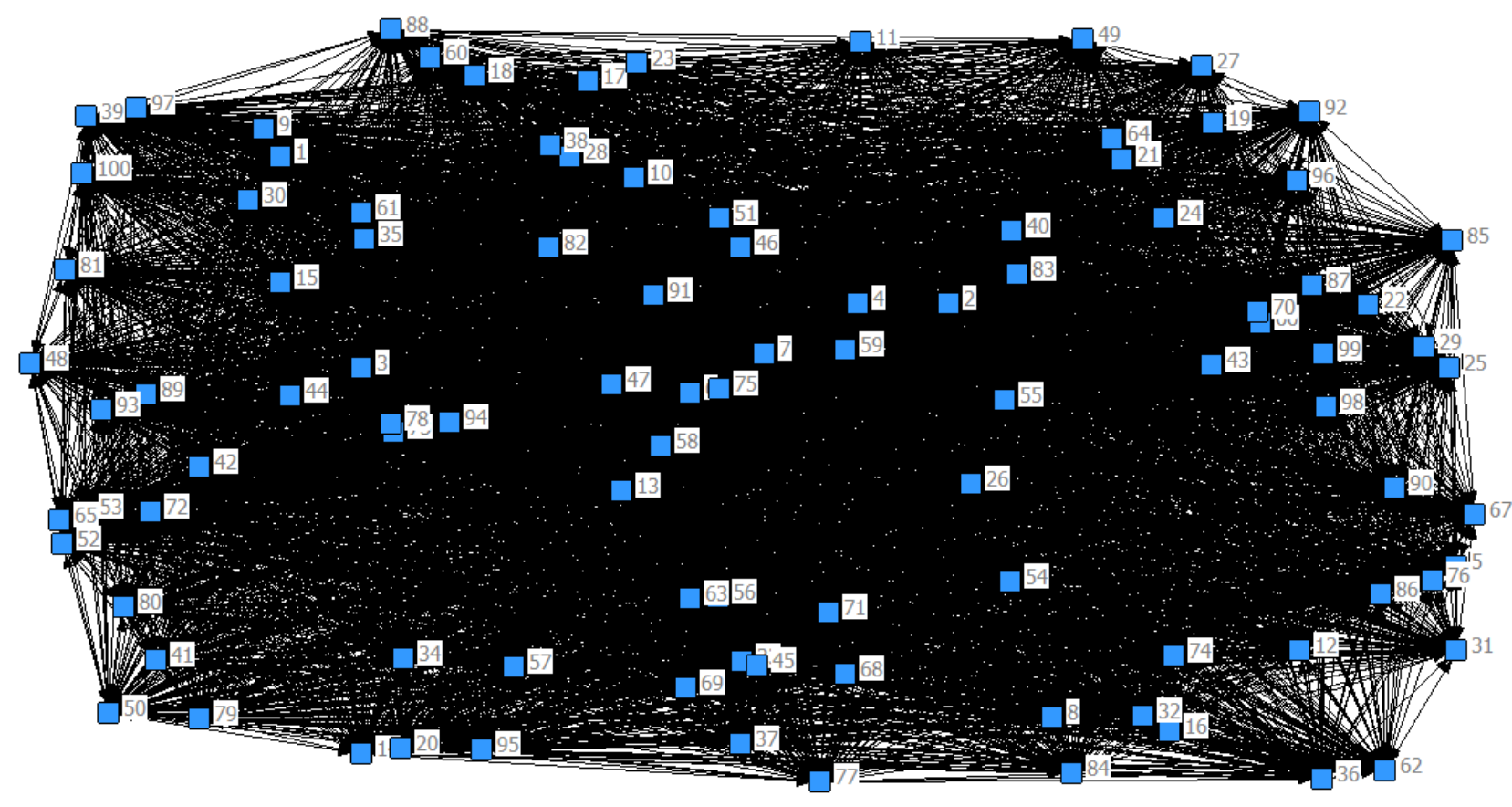




\section{List of Tables}

Table 1. Network Metrics Used

\begin{tabular}{lll}
\hline Network Metric & Definition & Interpretation \\
\hline Size & Number of actors or nodes & $\begin{array}{l}\text { Size is critical for understanding } \\
\text { overall network structure and } \\
\text { character (Hanneman, \& Riddle, } \\
2005) .\end{array}$ \\
& & Along with size, the number and \\
Relationships & Number of ties or links between & $\begin{array}{l}\text { types of relationships define social } \\
\text { network structure and character } \\
\text { (Hanneman, \& Riddle, 2005). } \\
\text { actors. }\end{array}$ \\
& & $\begin{array}{l}\text { Relationships both enable and } \\
\text { constrain; hence, depending on the } \\
\text { issue at hand, network size and } \\
\text { complexity may serve to increase or } \\
\text { limit performance (Borgatti, et al., } \\
\text { 2013). }\end{array}$
\end{tabular}

Organizations Number of distinct organizations in a network

Sandström and Rova (2010) suggest network heterogeneity is in part represented by diversity which is the number of distinct organizations comprising the network.

Cross-Boundary Number of ties connecting actors Exchange

Organization Type of different organizations divided by the total number of connections in the network expressed as a percentage (Sandström, \& Rova, 2010)

Number of different organizations in the network
Along with network diversity, crossboundary exchange is a measure of network heterogeneity (Sandström, \& Rova, 2010). Networks exhibiting high degrees of heterogeneity are diverse in knowledge base and communication exchanges and have increased capacity for innovation (Bodin, et al., 2006)

For the Upper Shavers Fork restoration, there were 9 different organization types including academia, county government, federal government, individual volunteers, media, non-governmental organizations (non-profits), private sector, regional government, and state government. 


\begin{tabular}{|c|c|c|}
\hline $\begin{array}{l}\text { Network } \\
\text { Degree } \\
\text { Centralization }\end{array}$ & $\begin{array}{l}\text { Freeman's approach - the degree } \\
\text { of inequality or variance of a } \\
\text { network compared to a perfectly } \\
\text { centralized star network of the } \\
\text { same size Hanneman and Riddle } \\
\text { 2005) }\end{array}$ & $\begin{array}{l}\text { Degree centralization is a measure of } \\
\text { how tightly a network is organized } \\
\text { around central point (i.e. how star- } \\
\text { like is the network: Figure } 22 \text { ) } \\
\text { (Fliervoet, et al., 2016). Networks } \\
\text { with higher degrees of centralization } \\
\text { may be more effective in problem } \\
\text { solving, and coordination ability, but } \\
\text { can stifle creativity andinnovation } \\
\text { (Bodin, et al., 2006; Angst, \& } \\
\text { Hirschi, 2016) }\end{array}$ \\
\hline Density & $\begin{array}{l}\text { Number of ties (relationships) } \\
\text { divided by maximum number of } \\
\text { possible (number nodes in } \\
\text { network) (Borgatti, et al., 2013) }\end{array}$ & $\begin{array}{l}\text { Density is a measure of network } \\
\text { connectedness and closure. Higher } \\
\text { network densities promote collective } \\
\text { action, development of trust in } \\
\text { exchanges, and resiliency } \\
\text { (redundancy in ties) (Fliervoet, et al., } \\
\text { 2016; Bodin, et al., 2006). However, } \\
\text { network densities that are too high } \\
\text { over time may lead to knowledge } \\
\text { homogenization and decreases in } \\
\text { problem solving capacity (Fliervoet, } \\
\text { et al., 2016) }\end{array}$ \\
\hline Diameter & $\begin{array}{l}\text { Network measure of reachability - } \\
\text { the number of steps maximally } \\
\text { necessary to reach from one } \\
\text { network node to any other (Bodin, } \\
\text { et al., 2006) }\end{array}$ & $\begin{array}{l}\text { Lower diameter networks offer } \\
\text { greater access to many actors or } \\
\text { nodes whereby social memory and } \\
\text { opportunities for social learning } \\
\text { increase (Bodin, et al., 2006) }\end{array}$ \\
\hline $\begin{array}{l}\text { Network } \\
\text { Betweenness } \\
\text { Centrality }\end{array}$ & $\begin{array}{l}\text { Network measure of how each } \\
\text { node minimizes distances between } \\
\text { other nodes in the network (Bodin } \\
\text { et al., 2005) }\end{array}$ & $\begin{array}{l}\text { Networks with higher betweenness } \\
\text { centrality have more separation } \\
\text { among subgroups which promotes } \\
\text { heterogeneity and access to novel } \\
\text { information; however, higher } \\
\text { betweenness can undermine trust and } \\
\text { represent vulnerabilities to } \\
\text { fragmentation with a loss of bridging } \\
\text { links (Bodin, et al., 2006) }\end{array}$ \\
\hline
\end{tabular}


Table 2. Ranking of Most Central Organizations

\begin{tabular}{l} 
Organization \\
\hline TIME Independent \\
WVDNR \\
WVU \\
CVI \\
NRCS \\
USFS \\
BEFORE Project
\end{tabular}

\section{WVU}

WVDNR

CVI

NRCS

USFS

\section{DURING Project}

WVDNR

WVU

CVI

NRCS

Snowshoe

\section{AFTER Project}

WVDNR

WVU

CVI

USFS

FRC

FUTURE Collaboration

WVDNR

CVI

WVU

WVDEP

USFS
Organiztaion

Type

Academia

State Gov't

NGO

Fed Gov't

Fed Gov't

Academia

State Gov't

NGO

Fed Gov't

Fed Gov't

State Gov't

Academia

NGO

Fed Gov't

Private

State Gov't

Academia

NGO

Fed Gov't

Media

Centrality

Rank

1

2

3

4

5

5

1
2
3
4
5

1
2
3
4
5

1

2

3

4

5

1

2

3

4

5

\begin{tabular}{ll} 
State Gov't & 1 \\
NGO & 2 \\
Academia & 3 \\
State Gov't & 4 \\
Fed Gov't & 5 \\
\hline
\end{tabular}


Table 3. Subject Matter Communication/Collaboration Over Time

\begin{tabular}{|c|c|c|c|c|c|}
\hline Timeframe & Planning & Funding & $\begin{array}{l}\text { Contruction/ } \\
\text { Implemenation }\end{array}$ & $\begin{array}{l}\text { Bio-physical } \\
\text { Monitoring }\end{array}$ & $\begin{array}{l}\text { Education/ } \\
\text { Outreach }\end{array}$ \\
\hline Time Independent & $38 \%$ & $13 \%$ & $15 \%$ & $14 \%$ & $20 \%$ \\
\hline Before Project & $49 \%$ & $17 \%$ & $10 \%$ & $10 \%$ & $14 \%$ \\
\hline During Project & $35 \%$ & $13 \%$ & $25 \%$ & $13 \%$ & $14 \%$ \\
\hline After Project & $33 \%$ & $9 \%$ & $11 \%$ & $20 \%$ & $26 \%$ \\
\hline Future & $36 \%$ & $14 \%$ & $13 \%$ & $14 \%$ & $23 \%$ \\
\hline
\end{tabular}


Table 4. Initial Roster

\begin{tabular}{ll}
\hline Stakeholder & Role \\
\hline WV Division of Natural Resources & Primary partner, implementation, program \\
development \\
West Virginia University & Primary partner, research, implementation \\
Canaan Valley Institute & Stream restoration expertise, outreach \\
WV Rail Authority & Stream corridor owner/ partner in logistics \\
Office of Congressman Alan B. Mollohan & Funding, vision \\
Eastern Brook Trout Joint Venture & Funding, research \\
National Resource Conservation Service & Funding, planning, implementation \\
Tygart Valley Conservation District & Funding, planning, implementation \\
WV Dept. of Environmental Protection & Stream permit regulator, ILF funding \\
Shavers Fork Coalition & Primary watershed stakeholder group, volunteers \\
US Forest Service & Major landowner, resource managers \\
US Army Corp of Engineers & Stream permit regulator \\
US Fish and Wildlife Service & Permit reviewer, RTE species \\
Cass Scenic Railroad State Park & Material delivery, recreation potential \\
Snowshoe Resort & Landowner access, recreation potential \\
Steve Callen & Landowner access, volunteer \\
Durbin Greenbrier Valley Railroad & Tourism, vision, logistics, recreation \\
Trakspec Railroad & Implementation \\
Snaptight, Inc. & Implementation \\
WV Department of Commerce & Public relations support \\
Trout Unlimited & Recreation, tourism \\
Cheat Mountain Club & History, tourism \\
Hatchery Run Homeowners Association & Volunteer labor \\
Mountain Air Services & Flight support, data acquisition \\
Greenbank Elementary & Volunteers, Tree Planting \\
The Nature Conservancy & Watershed restoration \\
High Action Program & Volunteer labor \\
Charleston Gazette Newspaper & Outreach \\
American Sportfishing Association & Funding, outreach \\
John Alevito & Volunteer labor \\
MPE Rentals & Equipment donation \\
WCHS 8 Eyewitness News & Outreach, education \\
FXmedia & Outreach, education \\
\hline &
\end{tabular}


Table 5. USF SNA Results

\begin{tabular}{|c|c|c|c|c|c|c|c|c|c|}
\hline$\overline{\text { USF Networks }}$ & $\begin{array}{l}\text { Size } \\
\text { (No.) }\end{array}$ & $\begin{array}{l}\text { Relation- } \\
\text { ships } \\
\text { (No.) }\end{array}$ & $\begin{array}{l}\text { Organ- } \\
\text { izations } \\
\text { (No.) }\end{array}$ & $\begin{array}{l}\text { Cross- } \\
\text { Boundary } \\
\text { Exchange }\end{array}$ & $\begin{array}{l}\text { Organ- } \\
\text { ization type } \\
\text { (No.) }\end{array}$ & $\begin{array}{l}\text { Network } \\
\text { Degree } \\
\text { Centralization }\end{array}$ & Density & $\begin{array}{l}\text { Diameter } \\
\text { (reachability) }\end{array}$ & $\begin{array}{l}\text { Network } \\
\text { Betweenness } \\
\text { Centrality }\end{array}$ \\
\hline \multicolumn{10}{|l|}{ TIME } \\
\hline Independent & 104 & 918 & 38 & $32.4 \%$ & 9 & $45.7 \%$ & $8.6 \%$ & 5 & $27.0 \%$ \\
\hline BEFORE Project & 55 & 332 & 19 & $27.1 \%$ & 7 & $40.3 \%$ & $11.2 \%$ & 5 & $37.5 \%$ \\
\hline DURING Project & 93 & 704 & 35 & $29.5 \%$ & 9 & $38.2 \%$ & $8.2 \%$ & 5 & $26.1 \%$ \\
\hline AFTER Project & 71 & 370 & 31 & $40.5 \%$ & 8 & $40.8 \%$ & $7.4 \%$ & 6 & $32.1 \%$ \\
\hline \multicolumn{10}{|l|}{ FUTURE } \\
\hline Collaboration & 58 & 292 & 28 & $38.4 \%$ & 8 & $39.9 \%$ & $8.8 \%$ & 4 & $39.7 \%$ \\
\hline
\end{tabular}

Table 6. USF Network Dynamics in Relation to Outcomes

\begin{tabular}{lllll}
\hline USF Restoration & Before Project & During Project & After Project & Future \\
Effort Outcomes & Project & Project & Project & Collaboration \\
\hline
\end{tabular}

1- Restoration Plan

2- \$9 Million Funding

3- Adaptive Capacity

4- Effective Implementation

5- Social Learning

6- Technology Innovation

7- Resiliency and momentum

\begin{tabular}{llll}
$\mathrm{X}$ & & & \\
$\mathrm{X}$ & $\mathrm{X}$ & & \\
$\mathrm{X}$ & $\mathrm{X}$ & $\mathrm{X}$ & $\mathrm{X}$ \\
& $\mathrm{X}$ & & \\
$\mathrm{X}$ & $\mathrm{X}$ & $\mathrm{X}$ & $\mathrm{X}$ \\
& $\mathrm{X}$ & $\mathrm{X}$ & $\mathrm{X}$ \\
\hline
\end{tabular}

Table 7. Impact of Hypothetically Removing the Most Central Organizations (WVDNR, WVU, and CVI) from the USF Before Project Network

\begin{tabular}{lllllllll}
\hline USF Networks & $\begin{array}{l}\text { Size } \\
\text { (No.) }\end{array}$ & $\begin{array}{l}\text { Relation- } \\
\text { ships } \\
\text { (No.) }\end{array}$ & $\begin{array}{l}\text { Organ- } \\
\text { izations } \\
\text { (No.) }\end{array}$ & $\begin{array}{l}\text { Cross- } \\
\text { Boundary } \\
\text { Exchange }\end{array}$ & $\begin{array}{l}\text { Organ- } \\
\text { ization type } \\
\text { (No.) }\end{array}$ & $\begin{array}{l}\text { Network } \\
\text { Degree } \\
\text { Centralization }\end{array}$ & $\begin{array}{l}\text { Density Diameter } \\
\text { (reachability) }\end{array}$ & $\begin{array}{l}\text { Network } \\
\text { Betweenness } \\
\text { Centrality }\end{array}$ \\
\hline & & & & & & & & \\
BEFORE Project & 55 & 332 & 19 & $27.1 \%$ & 7 & $40.3 \%$ & $11.2 \%$ & 5 \\
REMOVE CENTRAL & 28 & 90 & 16 & $16.0 \%$ & 7 & $19.1 \%$ & $11.9 \%$ & 7 \\
\hline
\end{tabular}




\subsection{References}

Angst, M., \& Hirschi, C. (2016). Network dynamics in natural resource governance: A case study of Swiss landscape management. Policy Studies Journal, 0(0), 1-22.

Aronson, J., Blignaut, J.N., Milton, S.J., Le Maitre, D., Esler, K.J., Limouzin, A., Fontaine, C.,... Lederer, N. (2010). Are socioeconomic benefits of restoration adequately quantified? A meta-analysis of recent papers (2000-2008) in Restoration Ecology and 12 other scientific journals. Restoration Ecology, 18(2), 143154. http://dx.doi.org/10.1111/j.1526-100X.2009.00638.x.

Aronson J., Milton, S.J., \& Blignaut, J.N. (2007). Restoring natural capital: Science, business, and practice. Washington, DC: Island Press.

Aronson, A., Clewell, A.F., Blignaut, J.N., \& Milton, S.J. (2006). Ecological restoration: A new frontier for nature conservation and economics. Journal for Nature Conservation, 14(2006), 135-139.

Barnes-Mauthe, M., Gray, S.A., Arita, S., Lynham, J., \& Leung, P. (2015). What determines social capital in a social-ecological system? Insights from a network perspective. Environmental Management. 2015(55), 392-410.

BenDor, T., Lester, T.W., Livengood, A., Davis, A., \& Yonavjak, L. (2015). Estimating the size and impact of the ecological restoration economy. PLOS ONE, 10(6), 1-15.

Bodin, O., \& Crona, B.I. (2009). The role of social networks in natural resource governance: What relational patters make a difference? Global Environmental Change, 19(2009), 366-374.

Bodin, O., Crona, B.I., \& Ernstson, H. (2006). Social networks in natural resource management: What is there to learn from a structural perspective? Ecology and Society, 11(2), 1-9.

Bodin, O., \& Crona, B.I. (2008). Management of natural resources at the community level: Exploring the role of social capital and leadership in a rural fishing community. World Development. 36(12), 2763-2779.

Borgatti, S. P., Brass, D. J., \& Halgin, D. S. (2014). Social network research: confusions, criticisms, and controversies. In Brass, D.J., Labianca, G., Mehra, A., Halgin, D.S., \& Borgatti, S.P. (Eds.), Research in the Sociology of Organizations. Vol. 40. Emerald Publishing: Bradford, UK.

Borgatti, S.P., Everett, M.G., \& Johnson, J.C. (2013) Analyzing social networks. Washington, DC: Sage. 
Borgatti, S.P., \& Halgin, D.S. (2011). On network theory. Organizational Science. Articles in Advance, 1-14.

Borgatti, S.P., Mehra, A., Brass, D.J., \& Labianca, G. (2009). Network analysis in the social sciences. Science. 323, 892-895.

Borgatti, S.P., Everett, M.G., \& Freeman, L.C. (2002). Ucinet for Windows: Software for social network analysis. Harvard, MA: Analytic Technologies.

Brown, W. S. (2014). Ghost fishery returns to life. Wonderful West Virginia, March 2014. Retrieved from http://www.wonderfulwv.com/SiteCollectionDocuments/Archive/Mar2014.pdf

Burt, R.S. (2000). The network structure of social capital. In Staw, B.M., \& Sutton, R.I. (Eds.), Research in organizational behavior. Greenwich, CT: JAI Press.

Burt, R.S. (1992). Structural holes: The social structure of competition. Cambridge, MA: Harvard University Press.

Charles, A., \& Wilson L. (2009). Human dimensions of marine protected areas. ICES Journal of Marine Science, 66, 6-15.

Clarkson, R. B. (1990). On beyond leatherbark: The cass saga. Parsons, WV: McClain Printing Company.

Cheliotis, G. (2006). Social Network Analysis. Retrieved from http://www.saylor.org/site/wp-content/uploads/2013/01/BUS209-4.3.2SocialNetworkAnalysis.pdf

Coleman, J.S. (1988). Social capital in the creation of human capital. The American Journal of Sociology, 94, 95-120.

Collins, A., Rosenberger, R., \& Fletcher, J. (2005). The economic value of stream restoration. Water Resources Research. 41(2), 1-20.

Conley, A., Moote, M.A. (2010). Evaluating collaborative natural resource management. Society and Natural Resources, 16(5), 371-386.

Crona, B., \& Hubacek, K. (2010). The right connections: How do social networks lubricate the machinery of natural resource governance? Ecology and Society, 15(4), 1-18.

Cross, R., Parker, A., Prusak, L., \& Borgatti, S.P. (2001). Knowing what we know: supporting knowledge creation and sharing social networks. Organizational Dynamics 30(2): 100120. 
de Groot, R.S., Blignaut, J., van der Ploeg, S., Aronson, J., Elmqvist, T., \& Farley, J. (2013). Benefits of investing in ecosystem restoration. Conservation Biology, 27(6), 12861293. http://dx.doi.org/10.1111/cobi.12158.

Dredge, D., Hales, R., \& Jamal, T. (2013). Community case study research: Researcher operacy embeddness and making research matter. Tourism Analysis, 18(1), 29-43.

Eastern Brook Trout Joint Venture. (2011). Conserving the eastern brook trout: Action strategies. (Conservation Stategy/Habitat Work Group), 1-91.

Retrieved from

http://easternbrooktrout.org/reports/ebtjv-conservation-strategy

Egan, D., Hjerpe, E.E., \& Abrams, J. (2011). Human dimensions of ecological restoration: Integrating Science, Nature, and Culture. Washington, DC: Island Press.

Emery, M., \& Flora, C.B. (2006). Spiraling-up: Mapping community transformation with community capitals framework. Journal of the Community Development Society, 37(35) 19-35. http://www.ncrcrd.iastate.edu/pubs/flora/spiralingup.htm.

Everard, M., \& Powell, A. (2002). Rivers as living systems. Aquatic Conservation: Marine and Freshwater Ecosystems. 2002(12), 329-337.

Fischer, P.A., Vance-Borland, K., Jasny, L., Grimm, K.E., \& Charnley, S. (2016). A network approach to assessing social capacity for landscape planning: The case of fire-prone forests in Oregon, USA. Landscape and Urban Planning. 147(2016), 18-27.

Fliervoet, J.M., Geerling, G.W., Mostert, E., \& Smits, J.M. (2015). Analyzing collaborative governance through social network analysis: A case study of river management along the Waal River in the Netherlands. Environmental Management, 57, 355-367.

Folke, C., Hahn, T., Olsson, P., \& Norberg, J. (2005). Adaptive governance of social-ecological systems. Annual Review Environmental Resources, 30, 441-473.

Genskow, K.D., \& Born, G.S. (2006). Organizational dynamics of watershed partnerships: A key to integrated water resources management. Journal of Contemporary Water Research \& Education, 135, 56-64.

Granovetter, M. (1973). The strength of weak ties. American Journal of Sociology 78, 13601380.

Halgin, D.S., \& Brass, D. (2016). Centrality Lecture. University of Kentucky Links Workshop, 18. 
Halliday, A., \& Glaser, M. (2011). A management perspective on social ecological systems: A generic system model and its application to a case study from Peru. Human Ecology Review, 18(1), 1-18.

Hanneman, R.A., \& Riddle, M. (2005). Introduction to social network methods. Riverside, CA: University of California, Riverside. http://faculty.ucr.edu/ hanneman/

Hodge, I., \& Adams, W.M. (2016). Short-term projects versus adaptive governance: Conflicting demands in the management of ecological restoration. Land, 5(39), 1-17.

Lake, P.S., Bond, N., \& Reich, P. (2007). Linking ecological theory with stream restoration. Freshwater Biology, (2007)52, 597-615

Lin, N. (1999). Building a Network Theory of Social Captial. Connections. 22(1), 28-51.

Mandarano, L.A. (2009). Social network analysis of social capital in collaborative planning. Society \& Natural Resources, 22(3), 245-260. http://dx.doi.org/10.1080/08941920801922182

McClenachan, L., Lovell, S., \& Keaveney, C. (2015). Social benefits of restoring historical ecosystems and fisheries: alewives in Maine. Ecology and Society, 20(2), http://dx.doi.org/10.5751/ES-07585-200231.

McClenachan, L., Neal, B.P., Al-Abdulrazzak, D., Witkin, T., Fisher, K., \& Kittinger, J.N. (2014). Do community supported fisheries (CSFs) improve sustainability? Fisheries Research, 157, 62-69.

Noy, C. (2008). Sampling knowledge: the hermeneutics of snowball sampling in qualitative research. International Journal of Social Research Methodology. 11(4), 327-344.

National Research Council. (1992). Restoration of Aquatic Ecosystems: Science, Technology, and Public Policy. Washington, DC: The National Academies Press.

Olsson, P., Gunderson, L.H., Carpenter, S.R., Ryan, P., Lebel, L., Folke, C., and Holling, C.S. (2006). Shooting the rapids: Navigating transitions to adaptive governance of socialecological systems. Ecology and Society. 11(1), 1-18.

Onyx, J., \& Bullen, P. (2000). Measuring social capital in five communities. Journal of Applied Behavioral Science. 36(1), 23-42.

Ortega, E., \& Ulgiati, S. (Eds.). (2004). Proceedings of IV Biennial International Workshop "Advances in Energy Studies". Ecological and socioeconomic benefits of restoring 
impaired streams: Emergy-based valuation. Campinas, SP, Brazil: Unicamp.

Palmer, M.A., Bernhardt, E.S., Allan, J.D., Lake, P.S., Alexander, G., Brooks, S., ,.. Sudduth, E. (2005). Standards for ecologically successful river restoration. Journal of Applied Ecology. 2005(42), 208-217.

Petty, J. T., \& Merriam, E. P. (2012). Brook Trout Restoration. Nature Education Knowledge. 3(7), 1-8.

Petursdottir, T., Arnalds, O., Baker, S., Montanarella, L., \& Aradottir, A. (2013). A socialecological system approach to analyze stakeholders' interactions within a large-scale rangeland restoration program. Ecology and Society. 18(2), 29-39.

Philip, R., \& Beechie, T. (2013). Stream and watershed restoration: A guide to restoring riverine processes and habitats. Hoboken, NJ: John Wiley \& Sons.

Phillips, G. (2003). Success and Benefits of Stream Restoration. Watershed Update. 1(6), 1-3.

Prager, D., \& Pfeifer, C. (2015). Network approaches for understanding rainwater management from a social ecological systems perspective. Ecology and Society, 20(4), 1-13.

Prell, C., Hubacek, K., \& Reed, M. (2009). Stakeholder analysis and social network analysis in natural resource management. Society \& Natural Resources. 22(6), 501-518.

Pretty, J., \& Ward, H. (2001). Social capital and the environment. World Development, 29(2), 209-227.

Rahm, D. (2002). Toxic waste and environmental policy in the $21^{\text {st }}$ century United States. Jefferson, NC: McFarland \& Company.

Redman, C.L., Gave, M.J., \& Kuby, L.H. (2004) Integrating social science into the longterm ecological research (LTER) network: social dimensions of ecological change and ecological dimensions of social change. Ecosystems, 7(2), 161-171.

Rosgen, D. (1996). Applied River Morphology. Pagosa Spring, CO: Wildland Hydrology.

Sandstöm, A., \& Rova, C. (2010) The network structure of adaptive governance: a single case study of a fish management area. International Journal of the Commons, 4(1), 528-551/

Seavy, N.E., Gardali, T., Gregory, H., Golet, F., Griggs, T., Howell, C.A., Kelsey, R., Small, S.L., Viers, J.H., \& Weigand, J.F. (2009) Why climate change makes riparian restoration more important than ever: Recommendation for practice and research. Ecological Restoration. 27(3), 330-338.

Schusler, T.M., Decker, D.J., \& Pfeffer, M.J. (2003). Social learning for collaborative natural 
resource management. Society and Natural Resources, 15, 309-326

Selin, S.W., Pierskalla, C., Smalldone, D., \& Robinson, K. (2007). Social learning and building trust through a participatory design for natural resource planning. Journal of Forestry, 105(8), 421-425.

Spink, A., Hillman, M., Fryirs, K., Brierley, G., \& Lloyd, K. (2010). Has river rehabilitation begun? Social perspectives from the Upper Hunter catchment, New South Wales, Australia. Geoforum. 41(2010), 399-409.

Stein, C., Ernstson, H., \& Barron, J. (2011). A social network approach to analyzing water governance: The case of the Mkindo catchment, Tanzania. Physics and Chemistry of the Earth. 36(2011), 1085-1092.

Syvitski, J. (2012) Anthropocene: An epoch of our making. Global Change, 78, 12-17. BenDor, T., Lester, T.W., Livengood, A., Davis, A., \& Yonavjak, L. (2015). Estimating the size and impact of the ecological restoration economy. PLOS ONE, 10(1371), 1-15.

Timur, S., \& Getz, D. (2008). A network perspective on managing stakeholders for sustainable urban tourism. International Journal of Contemporary Hospitality Management. 20(4), 445-461.

West Virginia Cooperative Fish and Wildlife Research Unit. (2015). Cooperative research agreement: Monitoring restoration of the shavers fork brook trout fishery. (October Progress Report). West Virginia University. 


\subsection{Appendices}

8.1 WVDNR Aquatic Habitat Enhancement Program Plan DRAFT

\section{Aquatic Habitat Enhancement Program}

Prepared by Natural Resource Analysis Center, West Virginia University

For the Wildlife Resources Section, West Virginia Division of Natural Resources

DRAFT January 27, 2017

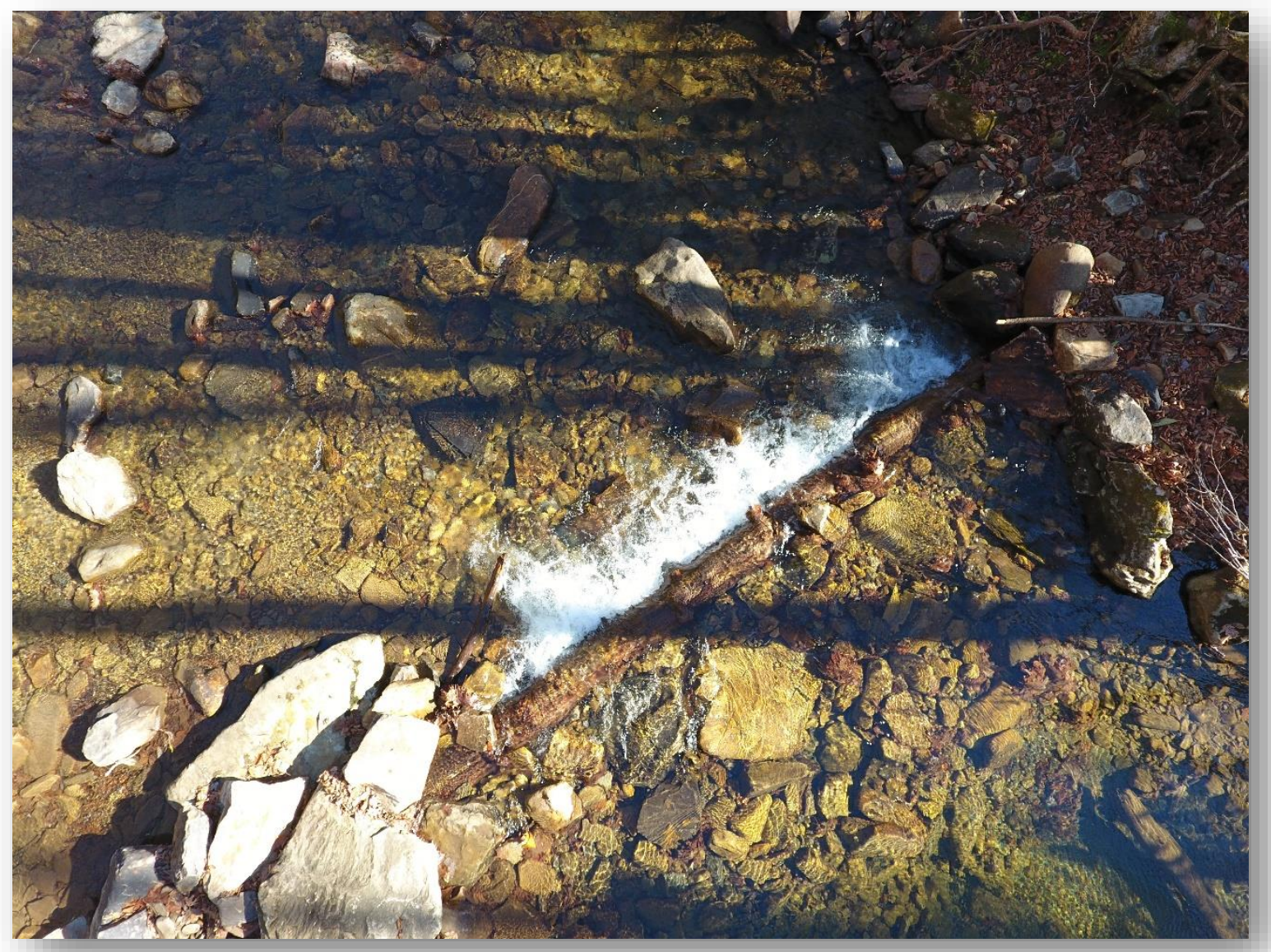




\section{BACKGROUND}

\subsection{Plan Purpose}

The West Virginia Division of Natural Resources' (WVDNR) Wildlife Resources Section (WRS) has a long history of conducting individual projects and activities whose objective has been to enhance aquatic habitat for the benefit of sport fish and the anglers who pursue them. To date however, aquatic habitat enhancement activities have not been elevated to program status in the agency. The benefits of organizing such activities under a major program for the agency include:

- Prioritization of aquatic habitat enhancement

- Continuity of commitment to the work

- Coordinated planning, staffing and budgeting

- Public visibility of the benefits of aquatic habitat enhancement

This plan has been developed to help the WRS develop and manage its Aquatic Habitat Enhancement Program (AHEP). The plan is designed to be a living document, to be adapted when new information becomes available, new objectives are established, new funding sources are identified, or when otherwise deemed necessary. 


\subsection{History}

Historically, the WRS's physical habitat enhancement activities have paralleled those of other fisheries managers across the nation. Examples included:

- Installation of K-dams and other instream structures

- Instream boulder installation

- Installation of gabions, rip rap, and other hard materials for bank stabilization

- Installation of brush piles and other subsurface fish attractors in reservoirs

- Planting of riparian vegetation

Certain of these techniques have fallen out of favor among fisheries managers, but many are still deployed to this day.

In recent years, the agency has initiated and completed significant projects to leverage the water quality improvements achieved by its acid water neutralization activities. In 2009, following years of research on limiting factors for the coldwater fishery in Upper Shavers Fork, the agency coordinated a watershed-level enhancement project involving multiple partners including West Virginia University (WVU), the Natural Resource Conservation Service (NRCS), the Tygart Valley Conservation District (TVCD), the West Virginia State Rail Authority (SRA), the US Forest Service (USFS), Snowshoe Corporation, the Durbin, Greenbrier Valley Railroad (DGVRR), Canaan Valley Institute (CVI), and others. Project objectives included increasing mainstem habitat diversity, decreasing mainstem water temperatures, and reconnecting tributaries blocked by passage barriers. The work there is ongoing, but the biological and physical effects of the work completed to date are being monitored by a team of WVU scientists through the West Virginia Cooperative Fish and Wildlife Research Unit.

In 2014, on the heels of the Shavers Fork project, the WRS initiated a stream habitat enhancement project on Mill Creek in Kumbrabow State Forest. Mill Creek, one of the state's intact populations of brook trout, had been impacted by storm-downed timber during a derecho and Superstorm Sandy in 2012. The storms provided an opportunity to deploy the large downed wood in a strategic manner to establish pools for late summer refugia and to increase overall aquatic habitat complexity. That work was completed in 2016.

In addition to its efforts in streams and rivers, the WRS is engaged in aggressive activities to enhance aquatic habitat in public impoundments. Several are being limed to reduce acidity and increase productivity. Others are the focus of innovative additions of anchored wood to provide cover for forage fish and the game fish that feed on them. Anglers are discovering that these habitat enhancement areas are productive areas to fish.

During the next five years, the WRS intends to significantly increase its efforts to enhance aquatic habitats in streams, rivers, and impoundments. As it does so, it will simultaneously focus on improving angler access to the recreational opportunities that are enhanced by these improvements.

In addition to its physical habitat enhancement activities, the WRS has emphasized acid water neutralization as a fisheries habitat management priority. Developed as a result of years of research, the WRS pioneered the use of self-feeding limestone drums and annual application of limestone sand to neutralize the toxic effects of acid precipitation on brook trout in poorly-buffered, high-elevation 
watersheds. Coldwater fisheries in almost 300 miles of headwater streams are sustained in this manner. The neutralization of headwater acidity also sustains warmwater fisheries and other aquatic life in receiving streams, rivers and impoundments. The WRS spends approximately $\$ 350,000$ annually on this highly successful and very popular effort. Having doubled the scope of this effort during the last decade, the agency anticipates a modest but meaningful expansion in the number of waters under its treatment during the next five years.

\subsection{Program Emphasis}

The AHEP will place its primary emphasis on enhancement of aquatic habitat in waters on or adjacent to public lands. These include:

- State lands

- State Parks

- State Forests

- State Wildlife Management Areas (WMA's)

- WVU lands

- Federal lands

- National Forests

- US Army Corps of Engineers lands

- National Park Service lands

- County and Municipal lands

The rationale for the program's focus on waters on public lands is threefold:

- It ensures public access to enhanced recreational opportunities that result from program activities.

- It protects habitat enhancements funded with public dollars.

- It focuses limited program funds on more heavily used sites.

The USFS has an active program of aquatic habitat enhancement on National Forest lands in West Virginia. The focus of that program includes instream and riparian habitat enhancement as well as removal of barriers to fish passage. Through the AHEP program, the WRS is certainly prepared to partner with the USFS on habitat projects on National Forest lands, but AHEP focus there will be principally on maintaining and expanding WRS activities to neutralize excess stream acidity in streams on the National Forests.

Looking ahead, priority enhancement activities for the AHEP in warm- and coldwater streams, rivers, and public impoundments are expected to include:

- Treatment of excess stream acidity with limestone sand

- Improving instream habitat complexity in streams and rivers

- Increasing structure and habitat complexity in public impoundments

- Restoring and managing woody riparian habits

- Removing barriers to passage of fish and other aquatic life 


\subsection{Fishable Streams and Impoundments on Public Lands}

For administrative purposes, the WVDNR divides the state into six management districts. Each district is staffed with a district fisheries biologist, an assistant district biologist and, in some cases, wildlife managers or fisheries technicians. These agency professionals are responsible for managing warmwater and coldwater fisheries in all waters in their district. Because waters on or adjacent to public lands generally receive the greatest angling pressure, these waters typically receive greater management emphasis. These waters support a variety of agency-managed, warmwater and/or coldwater fisheries consistent with existing habitat conditions.

Habitat quality in waters on public lands is often less than optimal for sport fish and other aquatic species. The historical and contemporary factors that have produced sub-optimal habitat in these waters are similar to those that impact aquatic habitat in waters flowing through or existing on private lands. They include:

- Acid deposition, both atmospheric and mining induced

- Excessive sedimentation from upstream sources

- Inadequate riparian habitat for shade and streambank stability

- Inadequate in-stream habitat complexity, particularly a scarcity of large, instream wood

- Barriers to passage of aquatic organisms

A number of streams, rivers and impoundments on public lands that have been impaired by atmospheric acid deposition are currently being treated annually with by the WRS with limestone to reduce stream acidity and sustain recreational fisheries. These waters are identified in Appendix A.

\section{PROGRAM GOALS}

The long-term goals of the AHEP are to:

- Increase the quality of aquatic habitats in selected streams and impoundments on public lands.

- Improve angler access to high-quality aquatic habitats in selected streams and impoundments on public lands.

- Maintain a high-quality angling experience by adaptively manage fish populations in enhanced streams and impoundments.

\section{PROGRAM OBJECTIVES}

Program objectives that must be met for the AHEP to achieve its long-term goals are as follows.

1. Develop and maintain a list of no less than three streams and impoundments per district where enhancement of aquatic habitat and angler access is a high priority for the WRS. 
2. Through the WRS's district management structure, implement no less than three habitat enhancement and angler access projects statewide each year.

3. For a period of five years after project implementation, annually assess effectiveness of all projects to enhance aquatic habitat and angler access and adapt designs as necessary.

4. Biennially monitor impacts of all projects on fish populations and adapt management as necessary to maintain angling quality to identified standards.

5. Identify and maintain program funding and staffing levels adequate to (1) implement no less than three projects statewide each year and (2) maintain the WRS's annual commitment to treatment of acid waters in the state.

6. Secure program MOU's with WVU and other key program partners to provide external assistance for project funding, design, and implementation.

\section{STRATEGIES TO ACHIEVE PROGRAM OBJECTIVES}

Objective 1: Develop and maintain a list of no less than three streams and impoundments per district where enhancement of aquatic habitat and angler access is a high priority for the WRS.

Strategy 1.1: The initial list of priority streams and impoundments will include those identified by district biologists in the 2016 query regarding public land priorities.

Strategy 1.2: Establish criteria for additions to the list of priority waters.

Strategy 1.3: Add streams and impoundments identified by fisheries managers to the list of priority waters.

Objective 2: Through the WRS's district management structure, implement no less than three habitat enhancement and angler access projects statewide each year.

Strategy 2.1: Utilize the aquatic habitat biologist position to coordinate project planning, environmental review, administration and other support to district fisheries biologists.

Strategy 2.2: Utilize the habitat program planning tool to assess agency capacity to implement habitat projects and schedule selected projects at least one-year in advance.

Strategy 2.3: Include project schedules in federal aid documents.

Objective 3: For a period of five years after project implementation, annually assess effectiveness of all projects to enhance aquatic habitat and angler access and adapt designs as necessary.

Strategy 3.1: Utilize a habitat assessment protocol to assess pre-construction habitat quality, identify impairments, and develop project plans. 
Strategy 3.2: Utilize a habitat assessment protocol to monitor project results annually for 5 years after project construction.

Strategy 3.3: Make project adjustments and adaptations as necessary.

Objective 4: Biennially monitor impacts of all projects on fish populations and adapt management as necessary to maintain angling quality to identified standards.

Strategy 4.1: Survey fish populations prior to project construction.

Strategy 4.2: Survey fish populations two years after project construction and then every two years thereafter.

Strategy 4.3: Develop or adopt metrics for angling quality.

Strategy 4.4: Apply angling quality metrics prior to project construction.

Strategy 4.5: Apply angling quality metrics two years after project construction and then every two years thereafter.

Strategy 4.6: Make management adjustments as necessary.

Objective 5: Identify and maintain program funding and staffing levels adequate to (1) implement no less than three projects statewide each year and (2) maintain the WRS's annual commitment to treatment of acid waters in the state.

Strategy 5.1: The AHEP should be led by an aquatic habitat biologist whose sole responsibility should be implementation of the program.

Strategy 5.2: The AHEP should be staffed with a wildlife aide/equipment operator trained in the fundamental concepts of constructing aquatic habitat enhancements.

Strategy 5.3: The AHEP should continue to be staffed with a resource specialist and support personnel whose function is to continue implementation of the WRS's acid waters treatment activities.

Strategy 5.4: The minimum baseline program funding level from all revenue sources should be approximately $\$ 750,000$.

Strategy 5.5: Program funding should grow as additional funding sources are identified and as project successes are achieved.

Objective 6: Secure program MOU's with WVU and other key program partners to provide external assistance for project funding, design, and implementation.

Strategy 6.1: Coordinate with the WV Cooperative Fish and Wildlife Research Unit and West Virginia University to facilitate aquatic habitat restoration in the state through training, education, research, networking and other project support.

Strategy 6.2: Develop programmatic MOU's with WVU, WVDOF, WVDEP, WVDOT, WVSCA, USACE, NRCS, USFS and others to share aquatic habitat enhancement priorities and collaborate on habitat project development and implementation. 


\section{STRATEGY IMPLEMENTATION 2017-2021}

Successful implementation of the program strategies identified in Section 4 will require a commitment of the WRS's human and financial resources. Below is a detailed discussion of each strategy, with recommended actions and commitments of agency resources during the first five years of the program.

Strategy 1.1: The initial list of priority streams and impoundments will include those identified by district biologists in the 2016 query regarding public land priorities.

Action: An initial list of waters on public lands prioritized for potential restoration or enhancement of aquatic habitat has been developed as a deliverable under the existing WVDNR/WVU cooperative agreement. That list is included as Appendix B of this plan. Future projects will be selected and implemented from this list, as amended. The list can be amended as necessary to reflect opportunities for project implementation.

Timetable: 2017

Estimated Cost: Included in existing WVDNR/WVU cooperative agreement

Status: Accomplished and included in this plan

\section{Strategy 1.2: Establish criteria for additions to the list of priority waters.}

Action: Suggested criteria for inclusion of additional waters on the priority waters list are:

- An identified impairment to fish populations that could be addressed by aquatic habitat restoration/enhancement

- Waters largely on or flowing through public lands

For clarity, the priority list should be kept to a manageable size. Waters should be added to list sparingly, either replacing existing waters on the list, because a project has been implemented, or added to the list because new enhancement opportunities have been recognized.

Timetable: 2017

Estimated cost: Included in existing WVDNR/WVU cooperative agreement

Status: Recommended criteria have been developed and are included in this plan

Strategy 1.3: Add streams and impoundments identified by fisheries managers to the list of priority waters. 
Action: This will be a continuous activity under the program. Fisheries managers will submit additional waters for consideration for inclusion on the priority list subject to the criteria established under Strategy 1.2.

Timetable: Continuous activity 2017-2021

Estimated cost: Negligible

Status: Continuous activity

\section{Strategy 2.1: Utilize the aquatic habitat biologist position to coordinate project planning, environmental review, administration and other support to district fisheries biologists.}

Action: Coordinating with district fisheries biologists, the aquatic habitat biologist will both and accept and generate project concepts for waters on the priority waters list. The position will develop a template for project concepts that collects information about the potential project including:

1. Priority stream, river or impoundment

2. Public land site

3. Nature of proposed habitat work

4. Extent (feet, miles, acres, \# barriers) of proposed work

5. Estimated cost

6. Estimated time required

7. In-agency or contracted work

8. Future maintenance considerations

9. Potential angler access to enhanced angling opportunities

The aquatic habitat biologist will also coordinate with the environmental coordination unit to develop and utilize a template to collect any additional information from district biologists required for environmental permitting.

Prior to selection of any project for implementation, the aquatic habitat biologist will be responsible for ensuring that adequate funding and manpower are available for completion of the proposed project work. This includes assuring the collection of adequate pre- and postproject data to satisfy environmental permitting requirements and internal assessments of project effectiveness.

The position will be responsible for acquiring, maintaining and deploying any equipment, materials and supplies necessary for project implementation and for supervising any non-district agency personnel employed to assist with project implementation. Finally, the position will be responsible for completion of project reports necessary for internal agency assessment and compliance with federal aid and other grants.

Timetable: 2017 and then annually thereafter

Estimated cost: 1 FTE @ \$52,500 annually including fringe

Status: Recommended in this plan 


\section{Strategy 2.2: Utilize the provided Program Planning Tool to assess agency capacity to implement habitat projects and schedule selected projects at least one-year in advance.}

Action: An Excel planning tool has been developed as a deliverable under the existing WVDNR/WVU cooperative agreement. The Program Planning Tool provides AHEP program managers with a mechanism for estimating future funding levels and financial obligations for the program. Regular use of the planning tool can yield estimates of available, unobligated funding that can be dedicated to specific AHEP projects, thus facilitating selection of projects that fit within the program budget. The tool can then be used to schedule selected projects.

Timetable: Continuous activity 2017-2021

Estimated cost: Development costs for the planning tool are included in existing WVDNR/WVU cooperative agreement, annual use costs are negligible

Status: Development complete, annual use will be a continuous activity

\section{Strategy 2.3: Include project schedules in federal aid grant documents.}

Action: The AHEP planning tool described in Strategy 2.2 will be used to generate project schedules that will be included in AHEP federal aid grant documents.

Timetable: Continuous activity 2017-2021

Estimated cost: Negligible

Status: Continuous activity 


\section{Strategy 3.1: Utilize habitat assessment protocols to assess pre-construction habitat quality, identify impairments, and develop project plans.}

Action: For projects selected for implementation, pre-construction habitat quality will be assessed to establish a baseline, identify habitat impairments, and facilitate preparation of project construction plans. For smaller, non-mitigation projects, the visual habitat component of EPA's Rapid Bioassessment Protocol (RBP) will be the standard assessment protocol for habitat quality. For mitigation projects, a more detailed habitat assessment, such as the WV Stream and Wetland Valuation Metric or another function-based assessment, will be employed. Habitat assessments may be performed by WRS personnel or external contractors. Access to enhanced angling opportunities will be considered as an additional parameter in habitat assessment and will be addressed in project plans.

Timetable: Continuous activity 2017-2021

Estimated cost: $\$ 5,000$ per project

Status: Continuous activity dependent on project implementation

Strategy 3.2: Utilize habitat assessment protocols to monitor project results annually for 5 years after project construction.

Activity: Appropriate habitat assessments will be conducted annually for 5 years after project construction to monitor changes resulting from the project.

Timetable: Continuous activity 2017-2021

Estimated cost: $\$ 5,000$ per project per year

Status: Continuous activity dependent on project implementation

\section{Strategy 3.3: Make project adjustments and adaptations as necessary.}

Activity: Monitoring of project results described in Strategy 3.2 will allow timely adaptations to both existing and future projects, with the goal of increasing project effectiveness.

Timetable: Continuous activity 2017-2021

Estimated cost: Negligible cost, potential savings

Status: Continuous activity dependent on project implementation 


\section{Strategy 4.1: Survey fish populations prior to project construction.}

Activity: Prior to implementing habitat restoration/enhancement projects, fish populations in the project area will be surveyed to establish a baseline for comparison with post-construction surveys. Survey methodology will vary with the scale and cost of the project to be implemented.

Timetable: Continuous activity 2017-2021

Estimated cost: $\$ 5,000$ per project per year

Status: Continuous activity dependent on project implementation

\section{Strategy 4.2: Survey fish populations two years after project construction and then every two years thereafter.}

Activity: For each constructed project, fish populations will be surveyed every two years following construction of the project. Post-construction survey methodology will match preconstruction methodology.

Timetable: Continuous activity 2017-2021

Estimated cost: $\$ 5,000$ per project

Status: Continuous activity dependent on project implementation

Strategy 4.3: Develop or adopt metrics for angling quality.

Activity: It is recommended that the WRS develop or adopt cost-effective metrics for angling quality. When the agency commits limited resources to high-priority restoration/enhancement projects, the angling public should be expected to respond to expanded angling opportunities. It should be recognized that increased angler use has the potential to overwhelm fishery gains that accrue from habitat enhancement. The adoption of appropriate metrics for angling quality, perhaps derived from fish survey results, can provide greater insight into appropriate pro-active or reactive management strategies for constructed projects. As an example of an angling quality metric, the Colorado Division of Parks and Wildlife's Gold Medal Trout Water policy is included as Appendix C.

Timetable: 2017

Estimated cost: Incorporated task for the AHEP program manager

Status: Recommended

\section{Strategy 4.4: Apply angling quality metrics prior to project construction.}

Activity: Prior to implementing habitat restoration/enhancement projects, angling quality metrics should be applied in conjunction with fish population surveys in the project area to establish a baseline for comparison with post-construction metrics and surveys.

Timetable: Continuous activity 2017-2021

Estimated cost: $\$ 5,000$ per project 
Status: Continuous activity dependent on project implementation

Strategy 4.5: Apply angling quality metrics two years after project construction and then every two years thereafter.

Activity: For each constructed project, angler quality metrics will be applied every two years following construction of the project. Post-construction metrics methodology will match preconstruction methodology.

Timetable: Continuous activity 2017-2021

Estimated cost: $\$ 5,000$ per project

Status: Continuous activity dependent on project implementation

Strategy 4.6: Make fisheries management adjustments as necessary.

Activity: Assessment of project results described in Strategies 4.2 and 4.5 will allow the WRS to make fisheries management adjustments to maintain enhanced angling quality benefits resulting from constructed aquatic habitat projects.

Timetable: Continuous activity 2017-2021

Estimated cost: Negligible cost, potential savings

Status: Continuous activity dependent on project implementation

Strategy 5.1: The AHEP should be led by an aquatic habitat biologist whose sole responsibility should be implementation of the AHEP.

Activity: Hire a Wildlife Biologist III for the AHEP. Under the supervision of a Program Manager, the AHEP Biologist will be responsible for:

- maintaining adequate funding for the program from committed DNR funds, federal aid grants, and other external grants

- planning, budgeting, and scheduling habitat projects with the district fisheries biologists

- coordinating the collection of all baseline and post-construction data for AHEP projects

- acting as the principal coordinator for the AHEP working with WRS Environmental Coordination Unit personnel to meet all permitting and compliance requirements for AHEP projects

- maintaining an inventory of equipment and supplies necessary to assist district biologists with implementation of aquatic habitat projects

- supervising other program staff

- ensuring compliance with the requirements of federal-aid and other grants providing funding for the AHEP

This and all staffing recommendations for the AHEP are detailed in Appendix D.

Timetable: 2017 
Estimated Cost: $\$ 52,500$ annually including fringe

Status: Recommended in this plan

Strategy 5.2: The AHEP should be staffed with a Wildlife Aide/Equipment Operator trained in the fundamental concepts of aquatic habitat enhancement.

Activity: Hire a Wildlife Aide or Equipment Operator to assist the AHEP Biologist with project construction. See Appendix D.

Timetable: 2017

Estimated Cost: $\$ 30,000$ annually including fringe

Status: Recommended in this plan

Strategy 5.3: The AHEP should continue to be staffed with a Resource Specialist and support personnel whose function is to continue implementation of the WRS's acid waters treatment activities.

Activity: Maintain the three positions (ERS2, Wildlife Manager, Wildlife Aide) currently dedicated to WRS acid waters treatment activities. See Appendix D.

Timetable: Continuous activity 2017-2021

Estimated Cost: 3 FTE’s @ \$130,000 annually including fringe

Status: Continuous activity

Strategy 5.4: The initial recommended program funding level from all revenue sources is approximately $\$ 750,000$.

Activity: Until other funding sources are identified and secured, budget approximately $\$ 750,000$ annually for the AHEP. This level of funding will allow the AHEP to develop and sustain adequate program infrastructure, meet existing maintenance obligations, and implement a solid array of discretionary enhancement projects during the five-year planning period. Developed using the Program Planning Tool, the following appendices provide funding, budget and project sequencing detail to support this strategy:

- Appendix E provides default program funding estimates from identified sources.

- Appendix F provides projections of program funding for the five-year planning period.

- Appendix G provides estimates of program infrastructure costs if the recommendations of this plan are implemented.

- Appendix $\mathrm{H}$ contains estimates of all non-discretionary program costs, i.e., program infrastructure and existing maintenance obligations.

- Appendix I provides estimates of program funds that would be available for implementation of discretionary enhancement projects and a potential project sequence.

- Appendix J incorporates all projected non-discretionary and discretionary funding into a budget table for the program over the five-year planning period.

Timetable: Continuous activity 2017-2021 
Estimated Cost: $\$ 750,000$ annual program cost

Status: Recommended in this plan

Strategy 5.5: Program funding should grow as additional funding sources are identified and as project successes are achieved.

Activity: Beginning in 2017, additional sources of funding for aquatic habitat projects to be implemented in 2020-2021 should be identified and secured.

Timetable: Continuous activity 2017-2021

Estimated Cost: $\$ 50,000-\$ 100,000$ of additional funding recommended

Status: Recommended in this plan

Strategy 6.1: Coordinate with the WV Cooperative Fish and Wildlife Research Unit and West Virginia University to facilitate aquatic habitat restoration in the state through training, education, research, networking and other project support.

Activity: Consider collaboration with the Coop Unit, WVU and other agencies to develop and maintain a standing aquatic habitat enhancement program at the university. The WRS could be a standing and sustaining sponsor of such a program; the AHEP would derive benefits from the WVU program in the form of:

- $\quad$ potential employees trained in the principles of aquatic habitat restoration/enhancement

- assistance with project design and construction

- $\quad$ pre- and post-project research and monitoring

- increased communication among restoration/enhancement agencies and practitioners

- sharing of WRS restoration/enhancement priorities with other agencies, which could result in adoption, collaboration and cost-sharing opportunities

Timetable: Continuous activity 2017-2021

Estimated Cost: $\$ 75,000$ annually

Status: Recommended in this plan 


\section{Appendix A. Acidified waters currently being treated annually with limestone by the Wildlife Resources Section.}

\begin{tabular}{|c|c|c|}
\hline DNR_DIST & Stream/Lake & Watershed \\
\hline 1 & Beaver Creek & Big Sandy Creek \\
\hline 1 & Laurel Run & Dry Fork \\
\hline 1 & Little Laurel Creek & Big Sandy Creek \\
\hline 1 & Little Laurel Run & Big Sandy Creek \\
\hline 1 & Mill Creek Reservoir & Tygart Valley River \\
\hline 1 & North Fork Red Run & Dry Fork \\
\hline 2 & Roaring Run & Sleepy Creek \\
\hline 2 & Rock Cliff Lake & Cacapon River \\
\hline 3 & Barrenshe Run & Cranberry River \\
\hline 3 & Bearcamp Run & Buckhannon River \\
\hline 3 & Big Run & Gauley River \\
\hline 3 & Coal Fork & Gauley River \\
\hline 3 & Crouch Run & Shavers Fork \\
\hline 3 & Dilley Fork & Gauley River \\
\hline 3 & Dogway Fork & Cranberry River \\
\hline 3 & First Fork & Shavers Fork \\
\hline 3 & Fish Hatchery Run & Shavers Fork \\
\hline 3 & Fishing Hawk Creek & Shavers Fork \\
\hline 3 & Glade Run & Tygart Valley River \\
\hline 3 & Glade Run & Shavers Fork \\
\hline 3 & Hunters Run & Cherry River \\
\hline 3 & Laurel Creek & Cherry River \\
\hline 3 & Laurel Fork & Holly River \\
\hline 3 & Left Branch North Fork Cherry River & Cherry River \\
\hline 3 & Left Fork Tea Creek & Williams River \\
\hline 3 & Marsh Fork & Buckhannon River \\
\hline 3 & McGee Run & Shavers Fork \\
\hline 3 & Middle Fork Gauley River & Gauley River \\
\hline 3 & Middle Fork Williams River & Williams River \\
\hline 3 & Mill Creek & Tygart Valley River \\
\hline 3 & North Fork Cranberry River & Cranberry River \\
\hline 3 & North Fork Gauley River & Gauley River \\
\hline 3 & Otter Creek & Dry Fork \\
\hline 3 & Phillips Camp Run & Buckhannon River \\
\hline 3 & Potatoehole Fork & Tygart Valley River \\
\hline 3 & Red Run & Shavers Fork \\
\hline
\end{tabular}




\begin{tabular}{|c|c|c|}
\hline DNR_DIST & Stream/Lake & Watershed \\
\hline 3 & Right Fork Buckhannon River & Buckhannon River \\
\hline 3 & Right Fork Tea Creek & Williams River \\
\hline 3 & Right Fork Tenmile Creek & Buckhannon River \\
\hline 3 & Right Fork Turkey Creek & Gauley River \\
\hline 3 & Second Fork & Shavers Fork \\
\hline 3 & Shavers Fork & Shavers Fork \\
\hline 3 & South Fork Gauley River & Gauley River \\
\hline 3 & South Fork Red Creek & Dry Fork \\
\hline 3 & Stonecoal Run & Shavers Fork \\
\hline 3 & Sugar Creek & Williams River \\
\hline 3 & Turkey Creek & Gauley River \\
\hline 3 & Whitmeadow Run & Shavers Fork \\
\hline 4 & Bear Run & Cherry River \\
\hline 4 & Boley Lake & Manns Creek - New River \\
\hline 4 & Coats Run & Cherry River \\
\hline 4 & Cold Knob Fork & Cherry River \\
\hline 4 & Cold Spring Branch & Cherry River \\
\hline 4 & Hamrick Run & Cherry River \\
\hline 4 & Johnson Branch & Cherry River \\
\hline 4 & Laurel Creek & Cherry River \\
\hline 4 & Manning Branch & Cherry River \\
\hline 4 & Meadow Creek & Anthony Creek \\
\hline 4 & North Fork Cherry River & Cherry River \\
\hline 4 & Rabbit Run & Cherry River \\
\hline 4 & Rocky Run & Cherry River \\
\hline 4 & South Fork Cherry River & Cherry River \\
\hline 4 & Surbaugh Creek & Meadow River \\
\hline
\end{tabular}




\section{Appendix B. Initial WRS list of priority streams, rivers, and impoundments for enhancement of aquatic habitat.}

Streams and Rivers

\begin{tabular}{|c|c|c|c|c|}
\hline $\begin{array}{l}\text { DNR } \\
\text { District }\end{array}$ & Public Land & Stream/River & Enhancement Opportunity & SWAP CFA \\
\hline 1 & $\begin{array}{l}\text { Little Canaan } \\
\text { WMA }\end{array}$ & Blackwater River & $\begin{array}{l}\text { River runs through } \sim 2.5 \text { miles of Little Canaan } \\
\text { WMA. Riparian planting and remove small } \\
\text { dam that prevents upstream movement of fish } \\
\text { and warms water temperatures. }\end{array}$ & High Alleghenies \\
\hline 1 & $\begin{array}{l}\text { Coopers Rock } \\
\text { State Forest }\end{array}$ & Little Laurel Run & $\begin{array}{l}\text { Has been receiving limestone fines treatment } \\
\text { and the } \mathrm{pH} \text { is now adequate for Brook Trout } \\
\text { according to Dr. Kyle Hartman. Physical } \\
\text { habitat needs improved by addressing } \\
\text { sedimentation and the lack of pool complexity. }\end{array}$ & Cheat Canyon \\
\hline 1 & $\begin{array}{l}\text { Cheat Canyon } \\
\text { WMA }\end{array}$ & Cheat River & $\begin{array}{l}\text { The Albright power station dam that was once } \\
\text { used to pool river for cooling water has } \\
\text { become obsolete since closure of power } \\
\text { station. Would open approximately } 60 \text { miles of } \\
\text { river. }\end{array}$ & Cheat Canyon \\
\hline 1 & $\begin{array}{l}\text { Cathedral } \\
\text { State Forest }\end{array}$ & Rhine Creek & $\begin{array}{l}\text { Native Brook Trout; good coop with PPK and } \\
\text { Yough chapters TU; lack of pool habitat; }\end{array}$ & \\
\hline 1 & $\begin{array}{l}\text { Beaver Creek } \\
\text { DOH } \\
\text { Easement }\end{array}$ & Beaver Creek & $\begin{array}{l}\text { Instream habitat; limestone sand; riparian } \\
\text { vertical structure }\end{array}$ & High Alleghenies \\
\hline 1 & $\begin{array}{l}\text { Cranesville } \\
\text { Swamp }\end{array}$ & $\begin{array}{l}\text { Pine Swamp } \\
\text { Run, Tankiln Run }\end{array}$ & Brook Trout restoration, instream habitat & \\
\hline 2 & $\begin{array}{l}\text { Edwards Run } \\
\text { WMA }\end{array}$ & Edwards Run & $\begin{array}{l}\text { Instream habitat, passage barrier removal, } \\
\text { riparian planting, possible bank stabilization; } \\
\text { enhancing riparian and instream conditions in } \\
\text { a downstream direction for a reestablished } \\
\text { native Brook Trout stream. }\end{array}$ & $\begin{array}{l}\text { Cacapon River } \\
\text { and Patterson } \\
\text { Creek }\end{array}$ \\
\hline 2 & $\begin{array}{l}\text { South Branch } \\
\text { WMA }\end{array}$ & $\begin{array}{l}\text { South Branch } \\
\text { River }\end{array}$ & $\begin{array}{l}\text { Instream habitat, large woody material } \\
\text { collection and retention, pool habitat } \\
\text { enhancement; it is a large stream, but the } \\
\text { South Branch and Cacapon rivers are incurring } \\
\text { ongoing instream habitat degradation due to } \\
\text { landscape management practices, it would be } \\
\text { great to think of something that could work in } \\
\text { these semi wadeable, super popular float trip } \\
\text { streams. }\end{array}$ & $\begin{array}{l}\text { Shenendoah and } \\
\text { Nathaniel } \\
\text { Mountains }\end{array}$ \\
\hline 2 & $\begin{array}{l}\text { Thorn Creek } \\
\text { WMA }\end{array}$ & Thorn Creek & $\begin{array}{l}\text { Instream habitat improvement, large woody } \\
\text { debris addition; we own the riparian of only a } \\
\text { very small portion ( } 1 / 2 \text { mile) of this very high } \\
\text { quality coldwater stream }\end{array}$ & $\begin{array}{l}\text { North Fork } \\
\text { Mountain/Thorn } \\
\text { Creek }\end{array}$ \\
\hline
\end{tabular}




\begin{tabular}{|c|c|c|c|c|}
\hline $\begin{array}{l}\text { DNR } \\
\text { District }\end{array}$ & Public Land & Stream/River & Enhancement Opportunity & SWAP CFA \\
\hline 2 & $\begin{array}{l}\text { Sleepy Creek } \\
\text { WMA }\end{array}$ & $\begin{array}{l}\text { Roaring Run } \\
\text { and/or Meadow } \\
\text { Branch }\end{array}$ & $\begin{array}{l}\text { Pool habitat improvement, possibly grip hoist } \\
\text { work, aimed at improving ground - surface } \\
\text { water interaction and improving surface water } \\
\text { longevity/quantity through summer periods } \\
\text { (increasing volume of Brook Trout summer } \\
\text { refugia); possible roads or paddocks built to } \\
\text { open Meadow Branch up for lime applications, } \\
\text { or riparian planting of historic beaver dams }\end{array}$ & $\begin{array}{l}\text { Sleepy Creek and } \\
\text { Back Creek }\end{array}$ \\
\hline 2 & $\begin{array}{l}\text { Reymann } \\
\text { Research } \\
\text { Farm WVU }\end{array}$ & $\begin{array}{l}\text { Moores Run \& } \\
\text { spring }\end{array}$ & $\begin{array}{l}\text { Aquaculture facility for rearing native Brook } \\
\text { Trout genetic groups for } \\
\text { reintroduction/enhancement }\end{array}$ & \\
\hline 3 & $\begin{array}{l}\text { Holly River } \\
\text { State Park }\end{array}$ & $\begin{array}{l}\text { Right Fork Little } \\
\text { Kanawha River, } \\
\text { Laurel Fork }\end{array}$ & Instream Habitat, fish passage, limestone sand & Central Reservoirs \\
\hline 3 & $\begin{array}{l}\text { Watoga State } \\
\text { Park }\end{array}$ & Greenbrier River & Instream habitat & $\begin{array}{l}\text { Greater } \\
\text { Greenbrier }\end{array}$ \\
\hline 3 & $\begin{array}{l}\text { Cass Scenic } \\
\text { Railroad State } \\
\text { Park }\end{array}$ & $\begin{array}{l}\text { Greenbrier } \\
\text { River, } \\
\text { Leatherbark } \\
\text { Creek }\end{array}$ & Instream habitat, fish passage, riparian habitat & $\begin{array}{l}\text { Greater } \\
\text { Greenbrier }\end{array}$ \\
\hline 4 & $\begin{array}{l}\text { Camp Creek } \\
\text { State Forest }\end{array}$ & Camp Creek & $\begin{array}{l}\text { Instream habitat, Brook Trout } \\
\text { restoration/management (southern strain?) }\end{array}$ & $\begin{array}{l}\text { Bluestone } \\
\text { Lake/Peters } \\
\text { Mountain }\end{array}$ \\
\hline 4 & $\begin{array}{l}\text { Bluestone } \\
\text { Lake WMA }\end{array}$ & Indian Creek & $\begin{array}{l}\text { Instream habitat, siltation due to agriculture, } \\
\text { enters New River, riparian restoration }\end{array}$ & $\begin{array}{l}\text { Bluestone } \\
\text { Lake/Peters } \\
\text { Mountain }\end{array}$ \\
\hline 4 & $\begin{array}{l}\text { Welch city } \\
\text { limits }\end{array}$ & Tug Fork & Instream habitat, easements, riparian & Cumberlands East \\
\hline 4 & $\begin{array}{l}\text { Kimball, } \\
\text { Keystone, } \\
\text { Northfork, } \\
\text { Elkhorn city } \\
\text { limits }\end{array}$ & Elkhorn Creek & Instream habitat, access easements, riparian & Cumberlands East \\
\hline 4 & $\begin{array}{l}\text { Panther State } \\
\text { Forest }\end{array}$ & $\begin{array}{l}\text { Panther Creek } \\
\text { and tribs }\end{array}$ & Instream habitat, & Cumberlands East \\
\hline 5 & $\begin{array}{l}\text { Boatable } \\
\text { River }\end{array}$ & Big Sandy of Elk & Instream habitat, muskies, easements, riparian & Lower Elk \\
\hline 5 & $\begin{array}{l}\text { RD Bailey } \\
\text { tailwaters }\end{array}$ & $\begin{array}{l}\text { Guyandotte } \\
\text { River }\end{array}$ & Instream habitat & $\begin{array}{l}\text { Cumberlands } \\
\text { West }\end{array}$ \\
\hline 5 & $\begin{array}{l}\text { Logan city } \\
\text { limits }\end{array}$ & $\begin{array}{l}\text { Guyandotte } \\
\text { River }\end{array}$ & instream habitat, easements, riparian & $\begin{array}{l}\text { Cumberlands } \\
\text { West }\end{array}$ \\
\hline 5 & $\begin{array}{l}\text { Kanawha } \\
\text { State Forest }\end{array}$ & $\begin{array}{l}\text { Davis Creek and } \\
\text { tribs }\end{array}$ & Instream habitat, fish passage & $\begin{array}{l}\text { Cumberlands } \\
\text { West }\end{array}$ \\
\hline 5 & $\begin{array}{l}\text { McClintic } \\
\text { WMA }\end{array}$ & Oldtown Creek & Instream habitat, erosion control & $\begin{array}{l}\text { Ohio River } \\
\text { Corridor }\end{array}$ \\
\hline 6 & $\begin{array}{l}\text { Spencer city } \\
\text { limits }\end{array}$ & Spring Creek & Instream habitat, riparian & $\begin{array}{l}\text { Little Kanawha/ } \\
\text { Middle Island } \\
\text { Creek }\end{array}$ \\
\hline
\end{tabular}




\begin{tabular}{lllll|}
$\begin{array}{l}\text { DNR } \\
\text { District }\end{array}$ & Public Land & Stream/River & Enhancement Opportunity & SWAP CFA \\
\hline 6 & $\begin{array}{l}\text { Wells Lock \& } \\
\text { Dam PAS }\end{array}$ & $\begin{array}{l}\text { Little Kanawha } \\
\text { River }\end{array}$ & $\begin{array}{l}\text { Fish passage structure - rock would be placed } \\
\text { both upstream and downstream of the existing } \\
\text { dam, that would be notched. }\end{array}$ & $\begin{array}{l}\text { Little Kanawha/ } \\
\text { Middle Island } \\
\text { Creek }\end{array}$ \\
\hline 6 & The Jug WMA & $\begin{array}{l}\text { Middle Island } \\
\text { Creek }\end{array}$ & $\begin{array}{l}\text { The "low water bridge" would be repaired - } \\
\text { allowing greater flows to pass through the } 7 \\
\text { mile long "jug" section of Midle Island Creek }\end{array}$ & $\begin{array}{l}\text { Little Kanawha/ } \\
\text { Middle Island } \\
\text { Creek }\end{array}$ \\
\hline
\end{tabular}




\section{Appendix B (Cont.). Initial WRS list of priority streams, rivers, and impoundments for enhancement of aquatic habitat.}

\section{Ohio, Kanawha and Monongahela Rivers}

\begin{tabular}{|c|c|c|c|c|}
\hline $\begin{array}{l}\text { DNR } \\
\text { District }\end{array}$ & Large River & Pool/Reach & Enhancement Opportunity & SWAP CFA \\
\hline 1 & Monongahela & $\begin{array}{l}\text { Hildebrand and } \\
\text { Opekiska pools }\end{array}$ & $\begin{array}{l}\text { Fish passage barrier, almost no barge } \\
\text { traffic on upper Mon River to open dam } \\
\text { locks and allow fish to move upstream. } \\
\text { Poor substrate habitat, silted, the only } \\
\text { "rifles" are immediately below dams. }\end{array}$ & \\
\hline 1 & Ohio River & Upper & $\begin{array}{l}\text { Bendway weirs to provide "riffle" habitat } \\
\text { within the pools. }\end{array}$ & $\begin{array}{l}\text { Ohio River } \\
\text { Corridor }\end{array}$ \\
\hline 4 & Kanawha & Kanawha Falls & Reduce bank erosion & $\begin{array}{l}\text { Kanawha } \\
\text { Falls }\end{array}$ \\
\hline 6 & Ohio River & Belleville Pool & $\begin{array}{l}\text { Rock structures (wing dams, etc) that } \\
\text { alter flow and current speeds }\end{array}$ & $\begin{array}{l}\text { Ohio River } \\
\text { Corridor }\end{array}$ \\
\hline 6 & Ohio River & Willow Island Pool & $\begin{array}{l}\text { Rock structures (wing dams, etc) that } \\
\text { alter flow and current speeds }\end{array}$ & $\begin{array}{l}\text { Ohio River } \\
\text { Corridor }\end{array}$ \\
\hline 6 & Ohio River & Racine Pool & $\begin{array}{l}\text { Rock structures (wing dams, etc) that } \\
\text { alter flow and current speeds }\end{array}$ & $\begin{array}{l}\text { Ohio River } \\
\text { Corridor }\end{array}$ \\
\hline
\end{tabular}




\section{Appendix B (Cont.). Initial WRS list of priority streams, rivers, and impoundments for enhancement of aquatic habitat.}

\section{Impoundments}

\begin{tabular}{|c|c|c|c|}
\hline $\begin{array}{l}\text { DNR } \\
\text { District }\end{array}$ & Impoundment & Enhancement Opportunity & SWAP CFA \\
\hline 1 & Tygart Lake & $\begin{array}{l}\text { Fish structures such as spider blocks, shoreline tree } \\
\text { cutting }\end{array}$ & \\
\hline 1 & Bear Rock Lake & $\begin{array}{l}\text { Drain and re-work impoundment. Impoundment has } \\
\text { aged and is choked with aquatic vegetation and is } \\
\text { filling with sediment to the point the upper } 1 / 3 \text { is not } \\
\text { useable. }\end{array}$ & $\begin{array}{l}\text { Northern } \\
\text { Panhandle }\end{array}$ \\
\hline 1 & Coopers Rock Lake & $\begin{array}{l}\text { Sediment needs dredged; sedimentation is not rapid } \\
\text { due to having state forest upstream. Project would } \\
\text { likely be affective for many years. }\end{array}$ & Cheat Canyon \\
\hline 2 & Warden Lake & $\begin{array}{l}\text { Vertical cover improvement, lake bed shading to } \\
\text { establish voids in vegetation }\end{array}$ & $\begin{array}{l}\text { Cacapon River } \\
\text { and Patterson } \\
\text { Creek }\end{array}$ \\
\hline 2 & Sleepy Creek Lake & $\begin{array}{l}\text { Vertical cover improvement, lake bed shading to } \\
\text { establish voids in vegetation, liming to increase } \mathrm{pH}+ \\
\text { alkalinity + productivity }\end{array}$ & $\begin{array}{l}\text { Sleepy Creek } \\
\text { and Back Creek }\end{array}$ \\
\hline 2 & Mount Storm Lake & $\begin{array}{l}\text { Timber felling to provide woody habitat (pending } \\
\text { Dominion approval), application of natural or } \\
\text { synthetic fish structures (plastic, wood and/or metal } \\
\text { artificial vegetation; rock pilings?) }\end{array}$ & $\begin{array}{l}\text { High } \\
\text { Alleghenies }\end{array}$ \\
\hline 3 & Summersville Lake & Adding structure: Woody, plastic, and concrete & \\
\hline 3 & Sutton Lake & Adding structure: Woody, plastic, and concrete & $\begin{array}{l}\text { Central } \\
\text { Reservoirs }\end{array}$ \\
\hline 3 & Burnsville Lake & Adding structure: Woody, plastic, and concrete & $\begin{array}{l}\text { Central } \\
\text { Reservoirs }\end{array}$ \\
\hline 3 & Stonecoal Lake & Adding structure: Woody, plastic, and concrete & $\begin{array}{l}\text { Central } \\
\text { Reservoirs }\end{array}$ \\
\hline 3 & Stonewall Jackson Lake & Adding structure: Woody, plastic, and concrete & $\begin{array}{l}\text { Central } \\
\text { Reservoirs }\end{array}$ \\
\hline 3 & $\begin{array}{l}\text { West Virginia Wildlife } \\
\text { Center }\end{array}$ & $\begin{array}{l}\text { Replacing aging dam structure and pond clean out as } \\
\text { well as fishing enhancements for angler recruitment }\end{array}$ & $\begin{array}{l}\text { Central } \\
\text { Reservoirs }\end{array}$ \\
\hline 4 & Hawk's Nest Lake & $\begin{array}{l}\text { Lots of siltation and aquatic veg, so needs some } \\
\text { "instream" work }\end{array}$ & Gorges \\
\hline 5 & Beech Fork Lake & $\begin{array}{l}\text { Annual 'felling' of shoreline trees where allowed (like } \\
\text { to reach around } 50 \text { per reservoir at least), placement } \\
\text { of xmas trees, signage, GPS habitat }\end{array}$ & $\begin{array}{l}\text { Cumberlands } \\
\text { West }\end{array}$ \\
\hline 5 & East Lynn Lake & $\begin{array}{l}\text { Annual 'felling' of shoreline trees where allowed (like } \\
\text { to reach around } 50 \text { per reservoir at least), placement } \\
\text { of xmas trees, signage, GPS pts of attractors/habitat }\end{array}$ & $\begin{array}{l}\text { Cumberlands } \\
\text { West }\end{array}$ \\
\hline 5 & Chief Logan Pond & Structures & $\begin{array}{l}\text { Cumberlands } \\
\text { West }\end{array}$ \\
\hline
\end{tabular}




\begin{tabular}{lll}
\hline 5 & Kanawha State Forest & Structures \\
Pond & & Cumberlands \\
\end{tabular}

\title{
Appendix C. Example of an angling quality metric, the Colorado Gold Medal Waters policy (2009).
}

\author{
GOLD MEDAL WATERS
}

DEFINITIONS

Quality Trout: Any trout 14 inches or longer in length.

Gold Medal Water: A lake or stream that supports a trout standing stock of at least 60 pounds per acre, and contains an average of at least 12 quality trout per acre.

DESIGNATION OF GOLD MEDAL WATERS

The Division may designate a water as Gold Medal once it has been demonstrated that the fishery consistently meets the following criteria:

a. Produces a minimum trout standing stock of 60 pounds per acre

b. Produces a minimum average of 12 quality trout per acre

Gold Medal water designation can only be applied to waters of the State that are accessible for fishing by the general angling public.

MANAGEMENT GUIDELINES

The Division will manage Gold Medal waters using these guidelines:

a. Promote the preservation and protection of Gold Medal waters through cooperation with appropriate land management agencies.

b. Loss or degradation of Gold Medal water as a result of human actions may be the basis for requesting mitigation from the person or agency contributing to that loss or degradation.

c. Strive to improve habitat and biological integrity of coldwater resources with the intent of providing conditions that can sustain Gold Medal populations.

d. The Division can recommend fishing regulations for purposes of maintaining or exceeding Gold Medal population criteria. 
Appendix D. Recommended organizational structure and staffing for the Aquatic Habitat Enhancement Program.

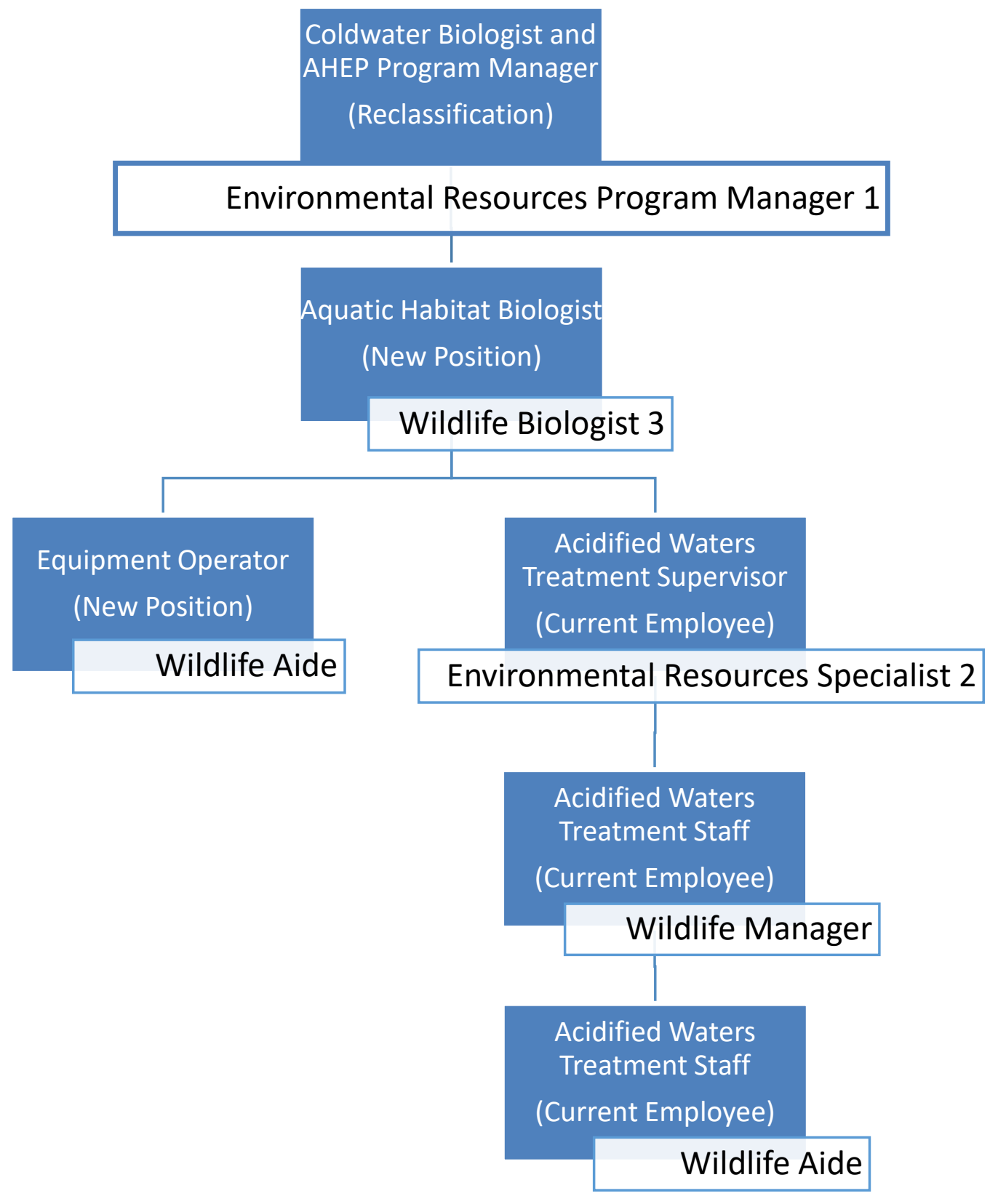




\section{Appendix E. Program Planning Tool: Default program funding estimates from identified sources.}

\section{Aquatic Habitat Enhancement Program Planning Tool \\ Program Funding Estimates Page}

Thursday, January 26, 2017

\begin{tabular}{|c|c|c|c|c|c|c|}
\hline \multicolumn{7}{|c|}{ Identify Program Funding Sources and Estimated Amounts } \\
\hline & & Funding Source & Potential Annual Funding & Stable Annual Funding & Potential Annual Grant Funding & Minimum Required \\
\hline Program Funding Source & Code & Restrictions & Available to Program & Available to Program & Available to Program & Non-Federal Match \\
\hline Endowment Fund - Aquatic Habitat Enhancement Account & WEF-AH & Acid Precip Streams & $230,261.00$ & $230,261.00$ & & \\
\hline Endowment Fund - Ohio River Account & WEF-OR & Ohio River \& Tribs & $\$$ & $\$$ & & \\
\hline Endowment Fund - Kanawha River Account & WEF-KR & Kanawha River \& Tribs & $\$$ & $\$$ & & \\
\hline Endowment Fund - Lifetime Trout Stamp Account & WEF-LT & Coldwater Streams & $\$$ & $\$$ & & \\
\hline Hunting and Fishing License Fund & HFLF & Fisheries & $100,000.00$ & $100,000.00$ & & \\
\hline Capital Improvements Account & $\mathrm{Cl}$ & Construction \& Land & $\$$ & $\$$ & & \\
\hline Federal Sport Fish Restoration & FSFR & Fisheries & $420,000.00$ & $420,000.00$ & & $140,000.00$ \\
\hline In-Lieu Fee Mitigation Fund & ILF & HUC Specific & DEP direct funded & DEP direct funded & DEP direct funded & $\$$ \\
\hline Other Grants - Eastern Brook Trout JV & EBTJV & Brook Trout & $49,000.00$ & & $49,000.00$ & $49,000.00$ \\
\hline Other Grants - Ohio River JV & ORJV & Ohio River Drainage & $50,000.00$ & & $50,000.00$ & $50,000.00$ \\
\hline Totals & & & $849,261.00$ & $750,261.00$ & $99,000.00$ & \\
\hline Federal Aid Funds $\%$ of Total & & & & $56 \%$ & & \\
\hline
\end{tabular}


Appendix F. Program Planning Tool: Projections of program funding for the five-year planning period.

\section{Aquatic Habitat Enhancement Program Planning Tool Program Funding Projections Page}

Thursday, January 26, 2017

\begin{tabular}{|c|c|c|c|c|c|c|c|}
\hline \multirow[b]{2}{*}{ Program Funding Source } & \multicolumn{7}{|c|}{ Annual Funding Projections } \\
\hline & 2017 & & 2018 & 2019 & & 2020 & 2021 \\
\hline WEF-AH & $\$ 100,000.00$ & $\$$ & $230,261.00$ & $\$ 230,261.00$ & $\$$ & $230,261.00$ & $\$ 230,261.00$ \\
\hline WEF-OR & $\$$ & $\$$ & - & $\$$ & $\$$ & - & $\$$ \\
\hline WEF-KR & $\$$ & $\$$ & - & $\$$ & $\$$ & - & $\$$ \\
\hline WEF-LT & $\$$ & $\$$ & - & $\$$ & $\$$ & - & $\$$ \\
\hline HFLF & $\$ 100,000.00$ & $\$$ & $100,000.00$ & $\$ 100,000.00$ & $\$$ & $100,000.00$ & $\$ 100,000.00$ \\
\hline $\mathrm{Cl}$ & $\$$ & $\$$ & - & $\$$ & $\$$ & - & $\$$ \\
\hline FSFR & $\$ 420,000.00$ & $\$$ & $420,000.00$ & $\$ 420,000.00$ & $\$$ & $420,000.00$ & $\$ 420,000.00$ \\
\hline ILF & DEP Direct & & Direct & DEP Direct & & Direct & DEP Direct \\
\hline EBTJV & $\$ 25,000.00$ & $\$$ & $49,000.00$ & $\$$ & $\$$ & $49,000.00$ & $\$$ \\
\hline ORJV & $\$$ & $\$$ & - & $\$ 50,000.00$ & $\$$ & - & $\$ 50,000.00$ \\
\hline Totals & $\$ 645,000.00$ & $\$$ & $799,261.00$ & $\$ 800,261.00$ & $\$$ & $799,261.00$ & $\$ 800,261.00$ \\
\hline
\end{tabular}




\section{Appendix G. Program Planning Tool: Estimates of program infrastructure costs.}

\section{Aquatic Habitat Enhancement Program Planning Tool Program Infrastructure Cost Estimation Page}

Thursday, January 26, 2017

\begin{tabular}{|c|c|c|c|c|c|c|c|c|c|c|c|}
\hline \multicolumn{11}{|c|}{ Estimate Program Infrastructure Costs for 5-Year Planning Period } & \\
\hline \multirow[b]{2}{*}{ Program Infrastructure Cost Centers } & \multicolumn{10}{|c|}{ Annual Cost Projections } & \\
\hline & & 2017 & \multicolumn{2}{|r|}{2018} & \multicolumn{2}{|r|}{2019} & \multicolumn{2}{|r|}{2020} & \multicolumn{2}{|r|}{2021} & \\
\hline \multicolumn{12}{|l|}{ PERSONAL SERVICES } \\
\hline Program Manager & & NA & & NA & & NA & & NA & & NA & \\
\hline Program Biologist & $\$$ & 36,339 & $\$$ & 36,339 & $\$$ & 36,339 & $\$$ & 36,339 & $\$$ & 36,339 & New position \\
\hline Resource Specialist & $\$$ & 35,000 & $\$$ & 35,000 & $\$$ & 35,000 & $\$$ & 35,000 & $\$$ & 35,000 & \\
\hline Wildlife Manager & $\$$ & 28,000 & $\$$ & 28,000 & $\$$ & 28,000 & $\$$ & 28,000 & $\$$ & 28,000 & \\
\hline Wildlife Aide & $\$$ & 20,000 & $\$$ & 20,000 & $\$$ & 20,000 & $\$$ & 20,000 & $\$$ & 20,000 & \\
\hline Equipment Operator (Wildlife Aide) & $\$$ & 21,437 & $\$$ & 21,437 & $\$$ & 21,437 & $\$$ & 21,437 & $\$$ & 21,437 & New position \\
\hline TOTAL PERSONAL SERVICES & $\$$ & 140,776 & $\$$ & 140,776 & $\$$ & 140,776 & $\$$ & 140,776 & $\$$ & 140,776 & \\
\hline EMPLOYEE BENEFITS & $\$$ & 70,388 & $\$$ & 70,388 & $\$$ & 70,388 & $\$$ & 70,388 & $\$$ & 70,388 & \\
\hline \multicolumn{12}{|l|}{ CURRENT EXPENSE } \\
\hline Supplies & $\$$ & 10,000 & $\$$ & 10,000 & $\$$ & 10,000 & $\$$ & 10,000 & $\$$ & 10,000 & \\
\hline Vehicle expense & $\$$ & 10,000 & $\$$ & 10,000 & $\$$ & 10,000 & $\$$ & 10,000 & $\$$ & 10,000 & \\
\hline Travel & $\$$ & 10,000 & $\$$ & 10,000 & $\$$ & 10,000 & $\$$ & 10,000 & $\$$ & 10,000 & \\
\hline WVU Contracts & $\$$ & 75,000 & $\$$ & 75,000 & $\$$ & 75,000 & $\$$ & 75,000 & $\$$ & 75,000 & \\
\hline TOTAL CURRENT EXPENSE & $\$$ & 105,000 & $\$$ & 105,000 & $\$$ & 105,000 & $\$$ & 105,000 & $\$$ & 105,000 & \\
\hline \multicolumn{12}{|l|}{ REPAIRS AND ALTERATIONS } \\
\hline \multicolumn{12}{|l|}{ EQUIPMENT } \\
\hline Total Program Infrastructure Costs & $\$$ & 316,164 & $\$$ & 316,164 & $\$$ & 316,164 & $\$$ & 316,164 & $\$$ & 316,164 & \\
\hline
\end{tabular}




\title{
Appendix H. Program Planning Tool: Estimates of all non-discretionary program costs.
}

\author{
Aquatic Habitat Enhancement Program Planning Tool \\ Program Base Cost Estimation Page \\ Thursday, January 26, 2017
}

\begin{tabular}{|c|c|c|c|c|c|}
\hline \multicolumn{6}{|c|}{ Compile Program Base Cost Estimates for 5-Year Planning Period } \\
\hline \multirow[b]{2}{*}{ Program Base Cost Centers } & \multicolumn{5}{|c|}{ Annual Cost Projections } \\
\hline & 2017 & 2018 & 2019 & 2020 & 2021 \\
\hline \multicolumn{6}{|l|}{ PROGRAM INFRASTRUCTURE COSTS } \\
\hline PERSONAL SERVICES & $\$ 140,776.00$ & $\$ 140,776.00$ & $\$ 140,776.00$ & $\$ 140,776.00$ & $\$ 140,776.00$ \\
\hline EMPLOYEE BENEFITS & $\$ 70,388.00$ & $\$ 70,388.00$ & $\$ 70,388.00$ & $\$ 70,388.00$ & $\$ 70,388.00$ \\
\hline CURRENT EXPENSE & $\$ 105,000.00$ & $\$ 105,000.00$ & $\$ 105,000.00$ & $\$ 105,000.00$ & $\$ 105,000.00$ \\
\hline REPAIRS AND ALTERATIONS & $\$$ & $\$$ & $\$$ & $\$$ & $\$$ \\
\hline EQUIPMENT & $\$$ & $\$$ & $\$$ & $\$$ & $\$$ \\
\hline TOTAL INFRASTRUCTURE COSTS & $\$ 316,164.00$ & $\$ 316,164.00$ & $\$ 316,164.00$ & $\$ 316,164.00$ & $\$ 316,164.00$ \\
\hline \multicolumn{6}{|l|}{ BASE MAINTENANCE OBLIGATIONS } \\
\hline ACID STREAM NEUTRALIZATION & $\$ 225,000.00$ & $\$ 225,000.00$ & $\$ 225,000.00$ & $\$ 225,000.00$ & $\$ 225,000.00$ \\
\hline ACCESS SITE MAINTENANCE & $\$ 50,000.00$ & $\$ 50,000.00$ & $\$ 50,000.00$ & $\$ 50,000.00$ & $\$ 50,000.00$ \\
\hline TOTAL BASE MAINTENANCE & $\$ 275,000.00$ & $\$ 275,000.00$ & $\$ 275,000.00$ & $\$ 275,000.00$ & $\$ 275,000.00$ \\
\hline Total Base Costs & $\$ 591,164.00$ & $\$ 591,164.00$ & $\$ 591,164.00$ & $\$ 591,164.00$ & $\$ 591,164.00$ \\
\hline
\end{tabular}




\section{Appendix I. Program Planning Tool: Estimates of program funds available for implementation of discretionary enhancement projects and a potential project sequence.}

\section{Aquatic Habitat Enhancement Program Planning Tool \\ Discretionary Project Funds Estimation Page}

Thursday, January 26, 2017

\begin{tabular}{|c|c|c|c|c|c|c|}
\hline \multicolumn{7}{|c|}{ Estimate Discretionary Project Funds for 5-Year Planning Period } \\
\hline & \multicolumn{5}{|c|}{ Annual Discretionary Funds Estimates } & \multirow[b]{2}{*}{ Notes } \\
\hline & 2017 & 2018 & 2019 & 2020 & 2021 & \\
\hline Estimated Program Revenue & $645,000.00$ & $799,261.00$ & $800,261.00$ & $799,261.00$ & $800,261.00$ & \\
\hline Estimated Base Costs for Program & $591,164.00$ & $591,164.00$ & $591,164.00$ & $591,164.00$ & $591,164.00$ & \\
\hline Estimated Discretionary Project Funds Available & $53,836.00$ & $208,097.00$ & $209,097.00$ & $208,097.00$ & $209,097.00$ & \\
\hline \multicolumn{7}{|l|}{ Detail on Discretionary Funds } \\
\hline ILF Project Planned & & & Yes & & Yes & \\
\hline EBTJV Project Planned & $25,000.00$ & $49,000.00$ & $\$$ & $49,000.00$ & $\$$ & \\
\hline ORJV Project Planned & $\$$ & $\$$ & $50,000.00$ & $\$$ & $50,000.00$ & \\
\hline Funds Committed to Match Planned EBTJV and ORJV Projects & $25,000.00$ & $49,000.00$ & $50,000.00$ & $49,000.00$ & $50,000.00$ & \\
\hline Discretionary Funds Available for Other Projects & $3,836.00$ & $110,097.00$ & $109,097.00$ & $110,097.00$ & $109,097.00$ & \\
\hline Possible project implementation & $\begin{array}{l}\text { Upper Shavers riparian } \\
\text { as EBTJV @ } \$ 50 \mathrm{~K} \text { and } \\
\text { impoundment work @ } \\
\$ 8 \mathrm{~K}\end{array}$ & $\begin{array}{l}\text { One EBTJV project @ } \\
\$ 98 \mathrm{~K} \text {, one warmwater } \\
\text { project @ } \$ 75 \mathrm{~K} \text {, and } \\
\text { impoundment work at } \\
\$ 39 \mathrm{~K}\end{array}$ & $\begin{array}{l}\text { One ORJV project @ } \\
\$ 100 \mathrm{~K}, \text { one coldwater } \\
\text { project @ \$75K, one ILF } \\
\text { project, and } \\
\text { impoundment work @ } \\
\text { \$38K }\end{array}$ & $\begin{array}{l}\text { One EBTJV project @ } \\
\$ 98 \mathrm{~K} \text {, one } \\
\text { warmwater project } \\
@ \$ 75 \mathrm{~K} \text {, and } \\
\text { impoundment work } \\
@ \$ 39 \mathrm{~K}\end{array}$ & $\begin{array}{l}\text { One ORJV project @ } \\
\$ 100 \mathrm{~K} \text {, one coldwater } \\
\text { project @ } \$ 75 \mathrm{~K} \text {, one ILF } \\
\text { project, and } \\
\text { impoundment work @ } \\
\$ 38 \mathrm{~K}\end{array}$ & $\begin{array}{l}\text { 5-year totals: } \\
11 \text { projects } \\
\text { plus } \\
\text { enhancements } \\
\text { at multiple } \\
\text { impoundments }\end{array}$ \\
\hline Pre-project work & \begin{tabular}{|l|} 
(1)Apply for EBTJV \\
project for 2018 \\
(2)catalyze an ILF \\
project for 2019 and \\
(3)permitting work for \\
2018 projects
\end{tabular} & $\begin{array}{l}\text { (1)Apply for ORJV } \\
\text { project for } 2019 \\
\text { (2)permitting work for } \\
2019 \text { projects }\end{array}$ & $\begin{array}{l}\text { (1)Apply for EBTJV } \\
\text { project for } 2020 \\
\text { (2)catalyze an ILF project } \\
\text { for } 2021 \text { and } \\
\text { (3)permitting work for } \\
2020 \text { projects }\end{array}$ & $\begin{array}{l}\text { (1)Apply for ORJV } \\
\text { project for } 2021 \\
\text { (2)permitting work } \\
\text { for } 2021 \text { projects }\end{array}$ & To be determined & \\
\hline
\end{tabular}




\title{
Appendix J. Program Planning Tool: Budget table for the program over the five-year planning period.
}

\author{
Aquatic Habitat Enhancement Program Planning Tool \\ Projected Program Budgets Page \\ Thursday, January 26, 2017
}

\begin{tabular}{|c|c|c|c|c|c|c|c|c|c|c|}
\hline \multicolumn{11}{|c|}{ Estimate Annual Program Budgets for 5-Year Planning Period } \\
\hline \multirow[b]{2}{*}{ Total Program Costs \& Revenue } & \multicolumn{10}{|c|}{ Annual Cost Projections } \\
\hline & \multicolumn{2}{|r|}{2017} & \multicolumn{2}{|r|}{2018} & \multicolumn{2}{|r|}{2019} & \multicolumn{2}{|r|}{2020} & \multicolumn{2}{|r|}{2021} \\
\hline \multicolumn{11}{|l|}{ PROGRAM INFRASTRUCTURE COSTS } \\
\hline PERSONAL SERVICES & $\$$ & $140,776.00$ & $\$$ & $140,776.00$ & $\$$ & $140,776.00$ & $\$$ & $140,776.00$ & $\$$ & $140,776.00$ \\
\hline EMPLOYEE BENEFITS & $\$$ & $70,388.00$ & $\$$ & $70,388.00$ & $\$$ & $70,388.00$ & $\$$ & $70,388.00$ & $\$$ & $70,388.00$ \\
\hline CURRENT EXPENSE & $\$$ & $105,000.00$ & $\$$ & $105,000.00$ & $\$$ & $105,000.00$ & $\$$ & $105,000.00$ & $\$$ & $105,000.00$ \\
\hline REPAIRS AND ALTERATIONS & $\$$ & - & $\$$ & - & $\$$ & - & $\$$ & - & $\$$ & - \\
\hline EQUIPMENT & $\$$ & - & $\$$ & - & $\$$ & - & $\$$ & - & $\$$ & - \\
\hline TOTAL INFRASTRUCTURE COSTS & $\$$ & $316,164.00$ & $\$$ & $316,164.00$ & $\$$ & $316,164.00$ & $\$$ & $316,164.00$ & $\$$ & $316,164.00$ \\
\hline \multicolumn{11}{|l|}{ BASE MAINTENANCE OBLIGATIONS } \\
\hline ACID STREAM NEUTRALIZATION & $\$$ & $225,000.00$ & $\$$ & $225,000.00$ & $\$$ & $225,000.00$ & $\$$ & $225,000.00$ & $\$$ & $225,000.00$ \\
\hline ACCESS SITE MAINTENANCE & $\$$ & $50,000.00$ & $\$$ & $50,000.00$ & $\$$ & $50,000.00$ & $\$$ & $50,000.00$ & $\$$ & $50,000.00$ \\
\hline TOTAL BASE MAINTENANCE & $\$$ & $275,000.00$ & $\$$ & $275,000.00$ & $\$$ & $275,000.00$ & $\$$ & $275,000.00$ & $\$$ & $275,000.00$ \\
\hline \multicolumn{11}{|l|}{ DISCRETIONARY PROJECT COSTS } \\
\hline CURRENT EXPENSE & $\$$ & $53,836.00$ & $\$$ & $208,097.00$ & $\$$ & $209,097.00$ & $\$$ & $208,097.00$ & $\$$ & $209,097.00$ \\
\hline TOTAL DISCRETIONARY PROJECT COSTS & $\$$ & $53,836.00$ & $\$$ & $208,097.00$ & $\$$ & $209,097.00$ & $\$$ & $208,097.00$ & $\$$ & $209,097.00$ \\
\hline TOTAL PROGRAM COSTS & $\$$ & $645,000.00$ & $\$$ & $799,261.00$ & $\$$ & $800,261.00$ & $\$$ & $799,261.00$ & $\$$ & $800,261.00$ \\
\hline TOTAL PROGRAM REVENUE & $\$$ & $645,000.00$ & $\$$ & $799,261.00$ & $\$$ & $800,261.00$ & $\$$ & $799,261.00$ & $\$$ & $800,261.00$ \\
\hline Projected Program Budgets & & 2017 & & 2018 & & 2019 & & 2020 & & 2021 \\
\hline PERSONAL SERVICES & $\$$ & $140,776.00$ & $\$$ & $140,776.00$ & $\$$ & $140,776.00$ & $\$$ & $140,776.00$ & $\$$ & $140,776.00$ \\
\hline EMPLOYEE BENEFITS & $\$$ & $70,388.00$ & $\$$ & $70,388.00$ & $\$$ & $70,388.00$ & $\$$ & $70,388.00$ & $\$$ & $70,388.00$ \\
\hline CURRENT EXPENSE & $\$$ & $433,836.00$ & $\$$ & $588,097.00$ & $\$$ & $589,097.00$ & $\$$ & $588,097.00$ & $\$$ & $589,097.00$ \\
\hline REPAIRS AND ALTERATIONS & $\$$ & - & $\$$ & - & $\$$ & - & $\$$ & - & $\$$ & - \\
\hline EQUIPMENT & $\$$ & - & $\$$ & - & $\$$ & - & $\$$ & - & $\$$ & - \\
\hline TOTAL ALL BUDGET CATEGORIES & $\$$ & $645,000.00$ & $\$$ & $799,261.00$ & $\$$ & $800,261.00$ & $\$$ & $799,261.00$ & $\$$ & $800,261.00$ \\
\hline
\end{tabular}


8.2 Stewards of Shavers Fork: PBS Documentary

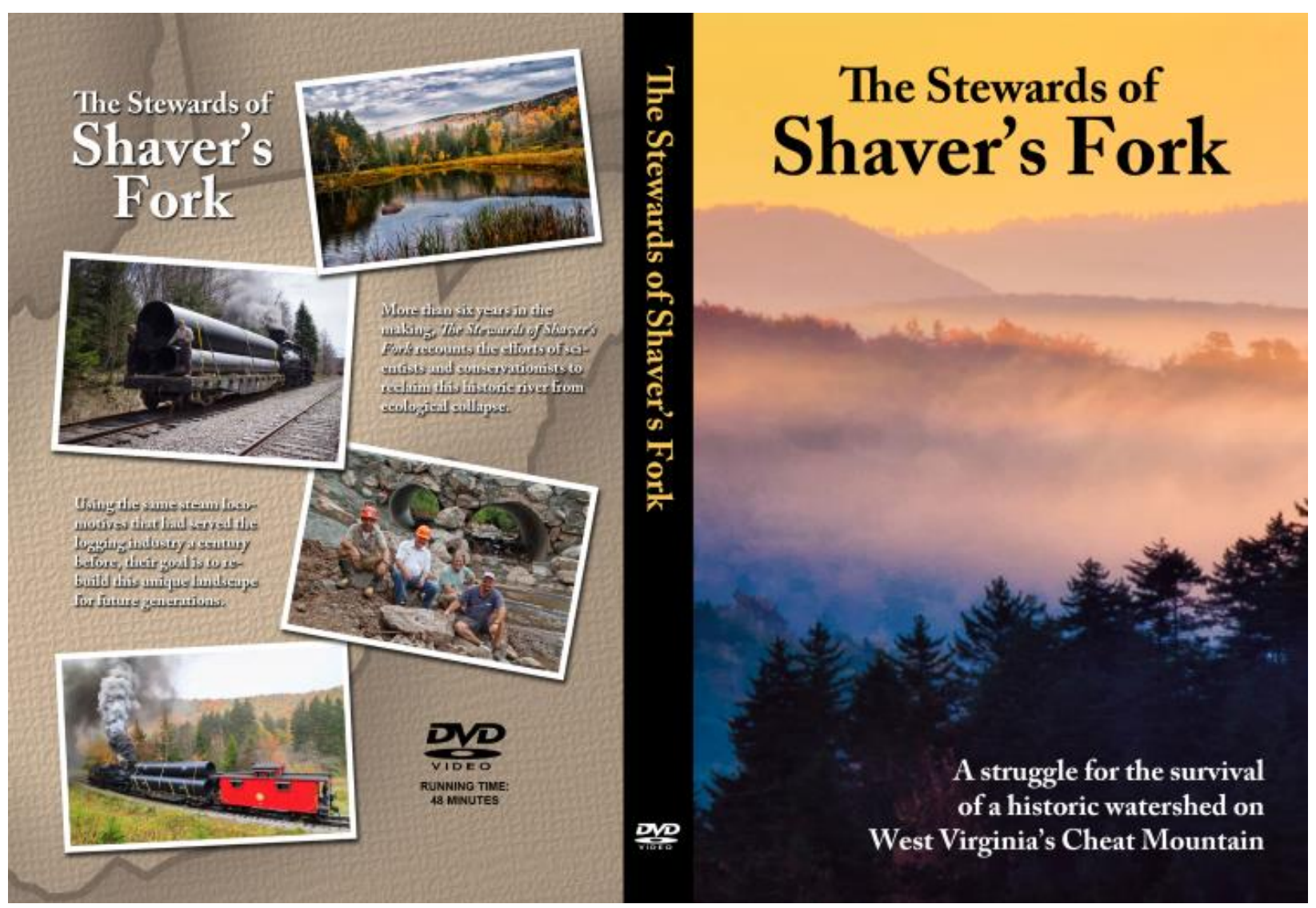




\subsection{Survey Instrument}

Thank you greatly for taking time to complete this survey. Data from this survey will be used in completing a West Virginia University (WVU) doctoral dissertation "Social capital gains in stream restoration: a social network analysis approach to Upper Shavers Fork, West Virginia" and in a final report to West Virginia Division of Natural Resources. The goal of this research is to more fully understand the Upper Shavers Fork (USF) network of partners in hopes to inform future restoration in the watershed and on other streams throughout West Virginia. All personal data will be kept strictly confidential by WVU researchers and network data (ties between participants) will be not published in a form to expose the identity of individuals. WVU's

Institutional Review Board acknowledgment of this project is on file. This survey should require approximately 15 minutes or less for the average respondent to complete and has been optimized for a computer-based Internet browser at a minimum screen resolution of $1280 \mathrm{x}$

960. Computers with lower screen resolution may require you to slide right to see more information and move to next question. Should you not be able to complete this survey on a computer, or should you just prefer an in person or phone interview, please contact Paul Kinder @ 304-612-0836 or (paul.kinder@mail.wvu.edu) to schedule a time at your convenience. We so very much appreciate your participation in the project and in this survey. The USF restoration effort is an evolving process and your input is extremely valuable. We will provide a summary of results to those participating in the survey as well as updates on future restoration plans.

Q7 Please tell us about yourself:

First name: (1)

Last Name: (2)

Zip Code: (6)

Q23 Your organization/business affiliation:

Organization: (1)

Position/Title: (2) 
Q9 Your Age:

O Under 18 (1)

O 18 - 24 (2)

O 25-34 (3)

O 35-44 (4)

O 45-54 (5)

O 55-64 (6)

O 65-74 (7)

O 75-84 (8)

O 85 or older (9)

Q10 Your Education:

Less than high school (1)

- High school graduate (2)

口 Some college (3)

․ 2 year degree (4)

- 4 year degree (5)

- Professional degree (6)

口 Doctorate (7)

Q24 Your Primary Scientific Discipline or Professional Background:

O Biology (1)

O Geology (2)

O Engineering (3)

O Geography (4)

O Economics (5)

O Environmental Science (6)

O Management/ Business (7)

O Agriculture (8)

O Tourism/ Recreation (9)

O Wildlife and Fisheries (11)

O Other (10)

Q5 Please select the individuals below that you collaborated and/or communicated with regarding Upper Shavers Fork, WV (USF) stream/watershed restoration over the past 10 years 
(check all that apply). You can add up to 5 other names should we have missed someone. This initial list of collaborators was generated by meeting notes, reports, and personal communication.

- Paul Kinder, WVU (11)

Eric Merriam, WVU (12)

Todd Petty, WVU (13)

Jerry Fletcher, WVU (14)

Charles Yuill, WVU (15)

Adam Riley, WVU (16)

Mike Gansor, WVU (31)

Dan Robison, WVU (32)

Steve Selin, WVU (84)

Tim Phipps, WVU (87)

口 Danny Bennett, WVDNR (2)

- Ray Menendez, WVDNR (3)

口 Dave Thorne, WVDNR (4)

B Bret Preston, WVDNR (5)

Scott Fortney, WVDNR Parks (6)

a Mike Shingleton, WVDNR (7)

Jack Cromer, WVDNR (8)

- John Rebinski, WVDNR (9)

Roger Anderson, WVDNR (10)

- Steve Brown, WVDNR (1)

口 Paul Johansen, WVDNR (33)

a Frank Jezioro, WVDNR (34)

- Bennie McCune, WVDNR Parks (54)

- Curtis Taylor, WVDNR (85)

Rob Sovine, WVDNR Parks (239)

口 Tom Oldham, WVDNR (238)

J Jennifer Newland, CVI (17)

- Ed Watson, CVI (18)

- Todd Miller, CVI (19)

- Will Postalhwait, CVI (20)

- Katrina High, CVI (21)

Ryan Gaujot, CVI (22)

口 Josh Saville, CVI (24)

- Kiena Smith, CVI (101)

- Ron Preston, CVI (171)

Cindy Butler, WVSRA (23)

- Alan Mollohan, WV Congressman (26) 
Ashley Lance, Office of Congressman Mollohan (28)

$\square$ Julie Aaronson, Office of Congressman Mollohan (100)

Kieth Burdette, WV Secretary Commerce (27)

口 Keith McGilvray, EBTJV (29)

Callie McMunigal, EBTJV (30)

Ron Wigal, NRCS (35)

$\square$ Angela Greene, NRCS (36)

$\square$ TJ Burr, NRCS (37)

Louis Aspey, NRCS (41)

Joe Gumm, TVCD (38)

$\square$ Sheldon Findley, TVCD (39)

口 James Nestor, TVCD (40)

Robert Wolfe, TVCD (93)

John Sencindiver, TVCD (94)

$\square$ Rex Reeder, TVCD (95)

$\square$ Joseph Shaffer, TVCD (96)

- Tom Warner, TVCD (97)

$\square$ Sigrid Teets, TVCD (98)

$\square$ David Bonner, TVCD (99)

$\square$ Sam Golston, Shavers Fork Coalition (44)

al Krueger, Shavers Fork Coalition (45)

口 Mark Tracy, Shavers Fork Coalition (76)

口 Jim VanGundy, Shavers Fork Coalition (130)

口 Russ McClain, Shavers Fork Coalition (131)

- Jon Magee, Shavers Fork Coalition (132)

Ken McCoy, Shavers Fork Coalition (133)

$\square$ Bryan Moore, TU (60)

口 Jack Tribble, USFS (49)

口 Mike Owen, USFS (50)

Tom Cain, USFS (51)

口 John Smith, DGVR (57)

$\square$ Brian Bridgewater, WVDEP (102)

T Teresa Koon, WVDEP (103)

E Ed Hamrick, WVDEP (42)

$\square$ Robin Dolly, WVDEP (104)

口 Randy Huffman, WVDEP (170)

$\square$ Gordon Blackley, CMC (46)

口 Kathyrn Parker, CMC (48)

$\square$ Jared Pritt, USACE (52) 
John Schmidt, USFWS (53)

$\square$ Steve Callen, Landowner (56)

$\square$ John Aliveto, volunteer (66)

口 Virgil Broughton, stakeholder (83)

a Anne Smith, Greenbank Elementary (62)

- John McCoy, Charleston Gazette (65)

口 Brad Rice, WCHS Channel 8 (67)

- Lisa Sherman, FXmedia (68)

$\square$ Curtis Flemming, Outdoor Channel (47)

口 Roger Lipscomb, Trakspec (58)

Ryan Harrington, Snaptite (59)

口 Bryan Mills, MAS (61)

Mike Anderson, NSE (75)

D Darrel Westmorland, NSE (74)

Seth Meeks, Trakspec (86)

Rodney Bartgis, TNC (63)

G Gordon Robertson, ASA (64)

口 Sarah Foe, Snowshoe (169)

¿ Ed Galford, Snowshoe (168)

$\square$ Other1? (69)

$\square$ Other2? (70)

Other3? (71)

Other4? (72)

$\square$ Other5? (73)

Q31 How often did you collaborate/communicate with $\$\{1 \mathrm{~m}: / /$ Field $/ 1\}$ during the time periods below (before, during, and after the Upper Shavers Fork restoration project)? How often would you anticipate future communication/collaboration with $\$\{\mathrm{~lm}: / /$ Field $/ 1\}$ regarding stream/watershed restoration on the Upper Shavers Fork or other streams? What was the 
primary subject matter of collaboration/communication during the time periods below (please check all that apply)?

\begin{tabular}{|c|c|c|c|c|c|c|c|c|c|c|}
\hline & \multicolumn{5}{|c|}{$\begin{array}{c}\text { communication/Collaboration } \\
\text { with } \$\{1 \mathrm{~m}: / / \text { Field } / 1\}\end{array}$} & \multicolumn{5}{|c|}{ Subject Matter } \\
\hline & $\begin{array}{l}\text { On } \\
\text { ce } \\
\text { (1) }\end{array}$ & $\begin{array}{l}\mathrm{Da} \\
\text { ily } \\
(2)\end{array}$ & $\begin{array}{l}\text { Wee } \\
\text { kly } \\
\text { (3) }\end{array}$ & $\begin{array}{l}\text { Mont } \\
\text { hly } \\
\text { (4) }\end{array}$ & $\begin{array}{l}\text { Yea } \\
\text { rly } \\
\text { (5) }\end{array}$ & $\begin{array}{l}\text { Plannin } \\
\text { g/ } \\
\text { Coordin } \\
\text { ation (1) }\end{array}$ & $\begin{array}{l}\text { Fund } \\
\text { ing } \\
\text { (2) }\end{array}$ & $\begin{array}{l}\text { Implemen } \\
\text { tation/ } \\
\text { Constructi } \\
\text { on (3) }\end{array}$ & $\begin{array}{l}\text { Biophy } \\
\text { sical } \\
\text { Monito } \\
\text { ring (4) }\end{array}$ & $\begin{array}{l}\text { Outre } \\
\text { ach/ } \\
\text { Educa } \\
\text { tion } \\
\text { (5) }\end{array}$ \\
\hline $\begin{array}{l}\text { Before } \\
\text { Project } \\
\text { (Before } \\
\text { 2009) (1) }\end{array}$ & 0 & 0 & 0 & 0 & 0 & व & a & ם & व & व \\
\hline $\begin{array}{c}\text { During } \\
\text { Project } \\
(2009- \\
2013)(2)\end{array}$ & 0 & 0 & 0 & 0 & 0 & ם & a & ם & ם & 口 \\
\hline $\begin{array}{c}\text { After } \\
\text { Project } \\
(2013- \\
\text { Now) (3) }\end{array}$ & 0 & $\mathrm{O}$ & 0 & 0 & 0 & 口 & $\square$ & $\square$ & 口 & 口 \\
\hline $\begin{array}{c}\text { Future } \\
\text { collaborat } \\
\text { ion/ } \\
\text { communi } \\
\text { cation } \\
\text { with } \\
\$\{1 \mathrm{lm:} / / \mathrm{Fi} \\
\text { eld } / 1\}(4)\end{array}$ & 0 & 0 & 0 & 0 & 0 & व & a & ם & व & व \\
\hline
\end{tabular}


Q12 In what types of stream/river related recreation do you participate (check all that apply)?

口 Fishing (1)

Hunting (2)

Swimming/Diving (3)

Float Trips (4)

Camping (5)

- Hiking (6)

Wildlife Watching (7)

$\square$ Other (8)

Q33 Are you a member of a conservation oriented organization (check all that apply)?

Trout Unlimited (1)

WV Rivers Coalition (2)

Friends of the Cheat (3)

Shavers Fork Coalition (4)

Other1? (5)

Other2? (6)

Other3? (7)

Q32 Do you recreate in the Upper Shavers Fork watershed?

O Yes (1)

O No (2)

Q11 Have you participated in a stream/watershed restoration project before Upper Shavers Fork?

O Yes (1)

No (2)

Q34 What was your motivation to participate in the Upper Shavers Fork restoration project (check all that apply)?

Job duty (1)

- Volunteer (2)

口 Other (3) 
Q35 Since 2009 approximately how much time have you spent in total working on the Upper Shavers Fork restoration project?

Less than 10 days (1)

O 11 to 50 days (2)

51 to 100 days (3)

○ 100 to 300 days (4)

O Over 300 days (5)

Q26 Have you participated in other stream/watershed restoration projects after Upper Shavers Fork? If so, please tell which ones.

Y Yes (1)

No (2)

Q14 How would you grade the success of Upper Shavers Fork restoration thus far?

○ 1 (1)

○ $2(2)$

○ $3(3)$

○ 4 (4)

○ $5(5)$

Q16 What could we have done differently or better in the Upper Shavers Fork restoration?

Q17 How likely are you to encourage, support, and/or participate in more stream/watershed restoration work in West Virginia?

Extremely likely (1)

O Somewhat likely (2)

Neither likely nor unlikely (3)

Somewhat unlikely (4)

Extremely unlikely (5)

Q18 Did you learn anything new from your participation in the Upper Shavers Fork restoration project? If so, what? 
Q19 How optimistic are you about the effectiveness of stream/watershed restoration in West Virginia?

Extremely optimistic (1)

Very optimistic (2)

Moderately optimistic (3)

Slightly optimistic (4)

Not optimistic at all (5)

Q22 Which other West Virginia streams/watersheds do you think should be a priority for aquatic habitat restoration?

Q23 The Upper Shavers Fork Restoration project has fueled momentum in stream restoration efforts throughout West Virginia.

Strongly agree (1)

Somewhat agree (2)

Neither agree nor disagree (3)

Somewhat disagree (4)

Strongly disagree (5) 
8.4 Highland Adventures of Mountains, Rivers, \& Rail

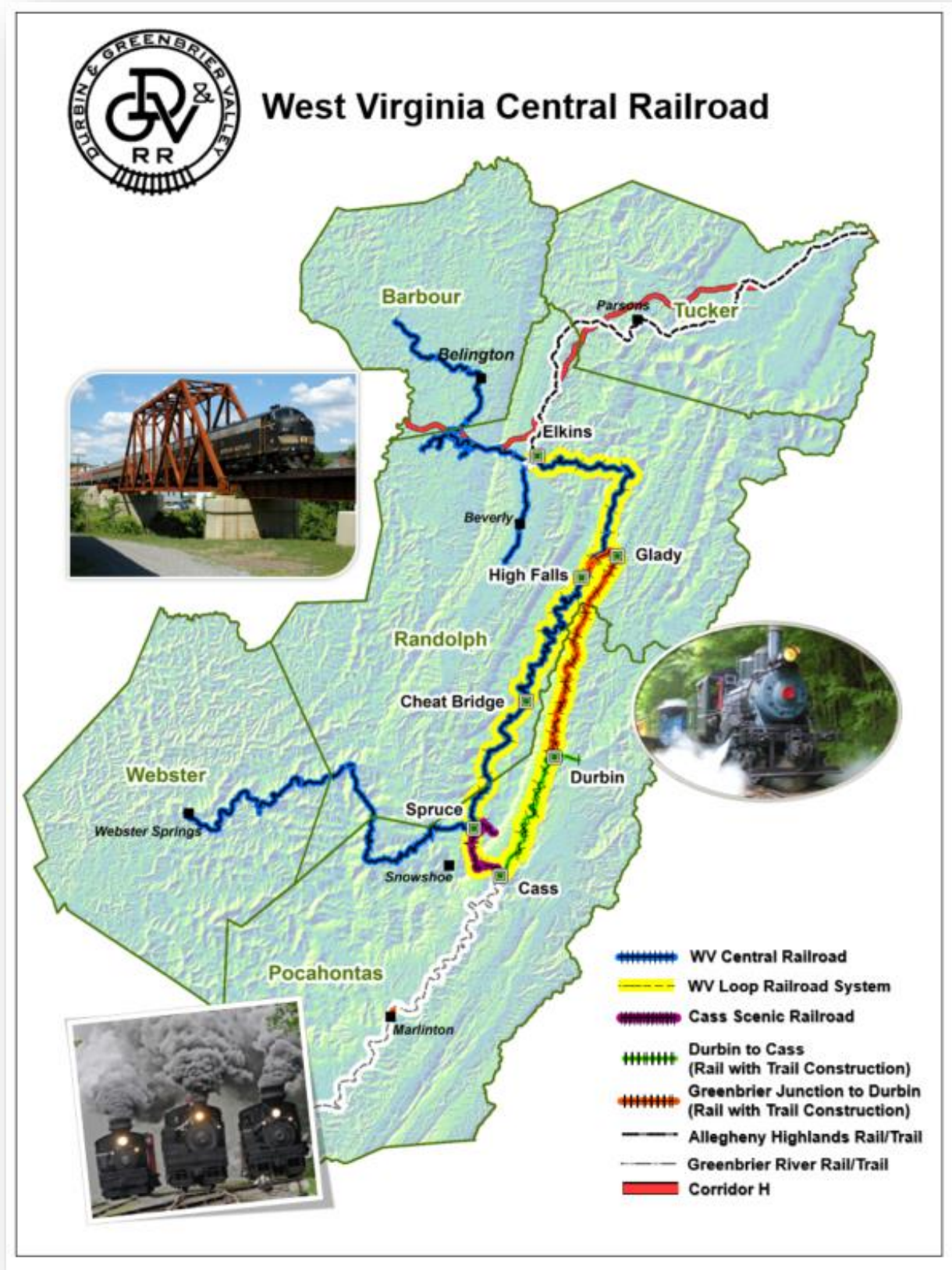


8.5 Mill Creek, WV Stream Habitat Restoration
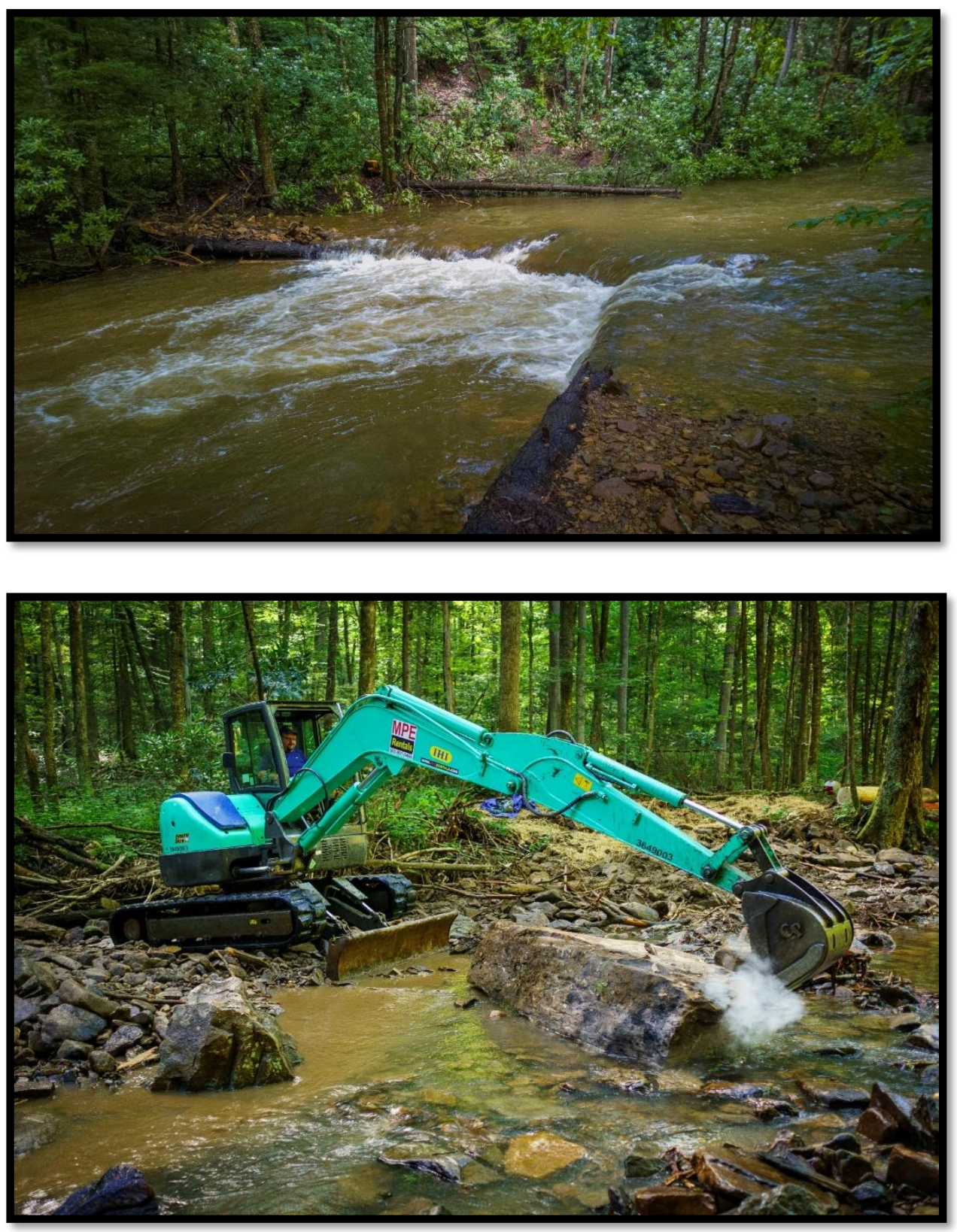